KALI FATIMA AMARAL

ANÁLISE DA CITOTOXICIDADE DO EDTA E DO ÁCIDO CÍTRICO APLICADOS EM CULTURA DE MACRÓFAGOS PERITONEAIS RESIDENTES

São Paulo

2004 
Kali Fatima Amaral

\title{
Análise da citotoxicidade do EDTA e do ácido cítrico aplicados em cultura de macrófagos peritoneais residentes
}

\begin{abstract}
Dissertação apresentada à Faculdade de Odontologia da Universidade de São Paulo, para obter o Título de Mestre, pelo programa de Pós-Graduação em Odontologia.
\end{abstract}

Área de Concentração: Endodontia

Orientador: Prof. Dr. Giulio Gavini

São Paulo 
Catalogação-na-Publicação

Serviço de Documentação Odontológica

Faculdade de Odontologia da Universidade de São Paulo

\section{Amaral, Kali Fatima}

Análise da citotoxicidade do EDTA e do ácido cítrico aplicados em cultura de macrófagos peritoneais residentes / Kali Fatima Amaral; orientador Giulio Gavini. -- São Paulo, 2004.

136p. : fig., tab., $30 \mathrm{~cm}$.

Dissertação (Mestrado - Programa de Pós-Graduação em Odontologia. Área de Concentração: Endodontia) -- Faculdade de Odontologia da Universidade de São Paulo.

1. Macrófagos peritoneais residentes - EDTA - Citotoxidade 2. Macrófagos peritoneais residentes - Ácido cítrico - Citotoxidade

3. Irrigantes do canal radicular 


\section{FOLHA DE APROVAÇÃO}

Amaral KF. Análise da citotoxicidade do EDTA e do ácido cítrico aplicados em cultura de macrófagos peritoneais residentes [Dissertação de Mestrado]. São Paulo:

Faculdade de Odontologia da USP; 2004.

São Paulo, 15/12/2004

\section{Banca Examinadora}

1) $\operatorname{Prof}(a) . \operatorname{Dr}(a)$.

Titulação:

Julgamento:

Assinatura:

2) $\operatorname{Prof}(a)$. Dr(a).

Titulação:

Julgamento:

Assinatura:

3) $\operatorname{Prof}(a) . \operatorname{Dr}(a)$.

Titulação:

Julgamento:

Assinatura: 
Dedicatória 


\section{Aos meus pais, Fatima e Amaral}

Presença, paciência, amor, silêncio, angústia, alegria, torcida...

Vocês me ensinaram a batalhar pelos meus ideais,

trilhando sempre o caminho da verdade,

integridade e lealdade

Tenho muito orgulho por ser sua filha

\section{Aos meus irmãos Gerson e Marcelo e cunhadas Maria Lúcia e Luciene}

Por todo o carinho e companheirismo que nos une

\section{Ao André e Alexandre}

Alegria da nossa família

Grandes amores da minha vida

\section{Ao Reinaldo Kaizuka}

O incentivo e compreensão na etapa final deste trabalho foram fundamentais

Fico muito feliz por fazer parte da minha história Você é o meu maior presente 
Agradecimentos 


\section{Ao meu orientador Prof. Dr. Giulio Gavini}

Minha carreira profissional e acadêmica não teria tomado este rumo sem a sua ajuda

Obrigada pelo exemplo,

Pelo voto de confiança,

Pelo constante apoio,

Pela amizade

Qualquer palavra é pouco para expressar a minha gratidão 


\section{À Profa. Dra. Primavera Borelli}

Pela maneira dedicada e decisiva com que conduz o Laboratório de Hematologia Clínica das Faculdades de Ciências Farmacêuticas da USP

Seu apoio e ensinamentos foram essenciais para o desenvolvimento experimental deste trabalho Por poder compartilhar experiências e conviver com um universo completamente novo - a pesquisa básica Por poder conhecer e trabalhar com pessoas tão competentes, agradáveis e generosas

Agradeço de coração 


\section{À Profa. Dra. Selma Cristina Cury Camargo}

Querida amiga, sempre dividindo as alegrias, inseguranças e ansiedades

Incentivadora e colaboradora dos momentos mais marcantes da minha trajetória

Percorrendo caminhos e objetivos comuns

Obrigada pela sua amizade sincera

\section{Ao Prof. Dr. Antonio Carlos Bombana}

Exemplo de seriedade e ética ao ensino da Odontologia

Pelas rápidas conversas no corredor do departamento que elucidaram muitos questionamentos

Pela disponibilidade e amabilidade

\section{À Profa. Dra. Márcia Martins Marques}

Responsável pelo meu contato inicial e treinamento na área de cultivo celular

Pela grande presença de espírito e vivacidade 


\section{Ao Marcelo Macedo Rogero e Ricardo Ambrósio Fock}

Pela incrivel paciência, empenho e auxílio

Pelos momentos de trabalho e descontração no laboratório

Sem "suas mãos", este trabalho não teria saído do papel

Muito obrigada por tudo

\section{À Mariana Cristina Ferreira Silva}

Por toda a ajuda na manipulação dos meios de cultura, coloração etc.

Pela grande amizade e carinho

\section{Ao pessoal do laboratório de Hematologia Clínica}

Prof. Táta, Marco Aurélio, Lorena, Ana, Amanda, Maria Emília, Solange, Rodolfo, Chico, Rose Pela animada e prazerosa companhia, tornando o ambiente do laboratório mais alegre

\section{Aos funcionários do Biotério do Conjunto das Químicas da USP}

Pela prontidão e disponibilidade durante a solicitação de animais

\section{Às minhas queridas amigas Patrícia Guillen e Renata Nassri}

A nossa amizade ultrapassa as barreiras do tempo e da distância

É muito bom poder contar com vocês

Aos colegas do curso de Pós-graduação

Mara Felippe, Bruno Cavalcanti, Vera Correia, Cristiane Esteves,

Adriana Ribeiro, José Lauriére, Christa Feller

Pela gratificante convivência e troca de informações

\section{À Cilene Turatti, Simone Mojica, Samanta Chu e Alice Shintani}

Amigas do coração, que me deram suporte e auxílio nas diferentes etapas deste trabalho

Ao Paulinho, da Faculdade de Farmácia da UNG e

Kátia, técnica do laboratório de Cultura de Células da FOUSP

Por toda a colaboração

Ao Sr. Aldo

Pela simpatia e disponibilidade em me ajudar, no que fosse preciso 


\section{Às bibliotecárias Aguida e Vânia}

Pela dedicação, correção bibliográfica e formatação da tese

\section{Aos amigos da Disciplina de Endodontia da UNISANTA}

Giulio Gavini, Danilo Shimabuko, Érico de Mello Lemos, Jacob Huli, Alexandre Bezerra, Maurílio Malavasi, Dirce Akemi Sacaguti, Paulo Bomfim, Eduardo Calil, Eduardo Akisue, Guilherme Figueiredo, Juliano Ribeiro, André Vasconcelos, Lícia Dias, Cynthia Duarte, João Paulo Romeu

Pelo respeito e carinho com os quais me tratam

\section{Ao Celso Luiz Caldeira}

Pela atenção e acompanhamento desde a época da graduação na UNICID

\section{Ao Érico de Mello Lemos e} colegas da Disciplina de Endodontia da UNG

Obrigada pela confiança em meu trabalho e por acreditar em mim

\section{À Equipe de Endodontia da UNICID}

Pela agradável convivência durante os anos, como estagiária didática

Aos alunos da Faculdade de Odontologia da FOUSP, UNICID, UNISANTA e UNG

Principais responsáveis pela busca do conhecimento e aprimoramento pessoal Com vocês, sou uma constante aprendiz

\section{À Dirce Akemi Sacaguti e Celina Moeller Gavini}

Pelos conselhos valiosos, incentivo e amizade

\section{A FAPESP e CNPq}

Pelo apoio financeiro

Ao Ser Supremo, aos Grandes, aos Poderosos, Ao Mestre Choa Kok Sui

Eu agradeço humildemente por suas bênçãos 
Amaral KF. Análise da citotoxicidade do EDTA e do ácido cítrico aplicados em cultura de macrófagos peritoneais residentes [Dissertação de Mestrado]. São Paulo: Faculdade de Odontologia da USP; 2004.

\section{RESUMO}

O presente estudo avaliou in vitro o efeito citotóxico das soluções de EDTA a 17\% e ácido cítrico a $15 \%$ sob macrófagos peritoneais residentes, valendo-se do método MTT. Após anestesia e sacrifício de 32 camundongos Swiss machos, procedeu-se a coleta do exsudato celular pela injeção e aspiração de meio de cultura estéril na cavidade abdominal dos animais. Pelo processamento do exsudato peritoneal, obteve-se em média $95 \%$ de macrófagos. Alíquotas de $5 \times 10^{5}$ células foram plaqueadas em triplicata, de acordo com os grupos experimentais. Diluições de $0,5 \%$ de EDTA e ácido cítrico foram adicionadas ao meio de cultura num total de $1 \mathrm{~mL}$. $\mathrm{O}$ grupo controle recebeu somente meio de cultura estéril. Verificou-se a citotoxicidade em dois momentos: períodos de curto prazo $(0,6,12$ e 24 horas) e médio prazo (1, 3, 5, 7 dias). Ao final dos referidos tempos de observação, as amostras foram tratadas pelo corante MTT, obtendo-se valores de absorbância em leitora ELISA 550 $\mathrm{nm}$. Todo o procedimento experimental foi repetido 2 vezes. No período de curto prazo, a análise de variância apontou diferenças significantes $(p<0,05)$, sendo $F_{c}=$ 46,07 contra $F_{t}=3,15$, para os grupos avaliados: os Grupos EDTA $(0,253 \mathrm{~nm})$ e ácido cítrico $(0,260 \mathrm{~nm})$ foram mais citotóxicos que o Grupo controle $(0,355 \mathrm{~nm})$. Observações de médio prazo revelaram significância estatística $(p<0,05)$ entre os grupos, sendo $F_{c}=171,0$ contra $F_{t}=3,15$. Ambas as soluções, EDTA $(0,158 \mathrm{~nm})$ e ácido cítrico $(0,219 \mathrm{~nm})$, mostraram maior toxicidade em relação ao controle $(0,310$ $\mathrm{nm}$ ), porém o EDTA apresentou-se mais citotóxico que o ácido cítrico, reduzindo substancialmente a população macrofágica. Como conclusão, as soluções irrigantes testadas exerceram toxicidade aos macrófagos peritoneais em cultura, no entanto, a viabilidade tardia destas células foi menos alterada pelo ácido cítrico.

Palavras-Chave: irrigantes do canal radicular - EDTA; toxicidade - ácido cítrico; toxicidade - cultura de células - macrófagos. 
Amaral KF. Cytotoxicity analysis of EDTA and citric acid applied on murine resident macrophages culture. [Dissertação de Mestrado]. São Paulo: Faculdade de

Odontologia da USP; 2004.

\section{ABSTRACT}

The present study evaluated in vitro cytotoxic effects of $17 \%$ EDTA and $15 \%$ citric acid in murine resident macrophages using MTT assay. After anesthesia and sacrifice of thirty two Swiss male mice, it had processed the peritoneal cellular exudates by fresh culture medium injection and aspiration in peritoneal animals cavities. The peritoneal exudates were composed approximately by $95 \%$ of macrophages. $5 \times 10^{5}$ cells were plated in triplicate, according experimental groups. Each $0.5 \%$ dilutions of EDTA and citric acid were applied in medium culture, resulting $1 \mathrm{~mL}$ volume. Fresh medium served as control. The cytotoxicity was evaluated in two moments: short term (0,6, 12, 24 hours) and long term (1, 3, 5, 7 days). After tested periods, the samples were treated by MTT ink assay and absorbance was determined using ELISA microplate reader at $550 \mathrm{~nm}$. All these procedures were repeated twice. To short term period, ANOVA showed significant differences $(p<$ $0.05)$ among groups $\left(F_{c}=46.07 \times F_{t}=3.15\right)$. EDTA $(0.253 \mathrm{~nm})$ and citric acid $(0.260$ $\mathrm{nm}$ ) groups exhibited more cytotoxicity than control group. Long term observations exhibited statistical differences $(p<0.05)$, that $F_{c}=171.0 \times F_{t}=3.15$. EDTA $(0.158 \mathrm{~nm})$ and citric acid $(0.219 \mathrm{~nm})$ solutions were cytotoxic when compared to control group, thus EDTA reduced greater macrophages viability than citric acid. Based on our results it seems that final irrigants tested presented toxic effects to murine macrophages culture, but in long term evaluation citric acid was considered less irritant.

Key words: root canal irrigants - EDTA; toxicity - citric acid; toxicity - cell culture macrophages 


\section{LISTA DE ILUSTRAÇÕES}

Figura 4.1 - Capela de fluxo laminar .58

Figura 4.2A - Punção e injeção do meio de cultura 59

Figura 4.2B - Massagem da região abdominal 59

Figura 4.2C - Corte e divulsão da pele e tecido subcutâneo 59

Figura 4.2D - Exposição da membrana peritoneal, destacando o exsudato formado 59

Figura 4.3A - Aspiração do exsudato peritoneal 60

Figura 4.3B - Aspiração do exsudato peritoneal em detalhe 60

Figura 4.3C - Transferência do esxudato peritoneal para tubo Falcon 60

Figura 4.4 - Centrifuga 61

Figura 4.5 - Placa de cultura dos grupos experimentais. 64

Figura 4.6A - Amostra experimental após o período de incubação com MTT 65

Figura 4.6B - Placa de cultura dos grupos experimentais após aplicação de corante MTT e solução reveladora SDS .65

Figura 4.7 - Verificação da absorbância da placa de cultura em leitora ELISA $550 \mathrm{~nm}$ 65 
Figura 4.8A - Placa de cultura das amostras-padrão .68

Figura 4.8B - Placa de cultura do padrão após aplicação de corante MTT e solução reveladora SDS. 68

Figura 5.1 - Absorbância média (nm) dos grupos experimentais, independente do tempo, para o período de curto prazo 71

Figura 5.2 - Absorbância média $(\mathrm{nm})$ nos diferentes intervalos de tempo, independente da solução testada, para o período de curto prazo. 72

Figura 5.3 - Absorbância média (nm) dos grupos, em função do tempo, para o período de curto prazo .73

Figura 5.4 - Absorbância média (nm) dos grupos experimentais, independente do tempo, para o período de médio prazo 74

Figura 5.5 - Absorbância média $(\mathrm{nm})$ nos diferentes intervalos de tempo, independente da solução testada, para o período de médio prazo.........76

Figura 5.6 - Absorbância média (nm) dos grupos, em função do tempo, para o período de médio prazo. 77

Figura 5.7 - Curva de viabilidade celular (concentração de macrófagos), em função da solução e tempo .79 


\section{LISTA DE TABELAS}

Tabela 5.1 - Absorbância média (nm) e desvio-padrão dos dados amostrais 69

Tabela 5.2 - Diferença entre as médias de absorbância dos grupos avaliados, para o período de curto prazo $(p<0,05)$

Tabela 5.3 - Diferença entre as médias de absorbância dos tempos avaliados, para o período de curto prazo $(p<0,05)$

Tabela 5.4 - Absorbância média (nm) e desvio-padrão, obtidos no período de curto prazo

Tabela 5.5 - Diferença entre as médias de absorbância dos grupos avaliados, para o período de médio prazo $(p<0,05)$

Tabela 5.6 - Diferença entre as médias de absorbância dos tempos avaliados, para o período de médio prazo $(p<0,05)$

Tabela 5.7 - Absorbância média (nm) e desvio-padrão, obtidos no período de médio prazo

Tabela 5.8 - Absorbância média ( $\mathrm{nm}$ ) e concentração de macrófagos, de acordo com os grupos e tempos experimentais .78

Tabela 5.9 - Relação entre a absorbância e concentração de macrófagos dos tempos experimentais.

Tabela 5.10 - Relação entre a absorbância e concentração de macrófagos dos tempos experimentais. 


\section{LISTA DE ABREVIATURA E SIGLAS}

$\begin{array}{ll}\text { EDTA } & \text { Ácido Etilenodiamino Tetracético } \\ \text { EDTAC } & \text { Ácido Etilenodiamino Tetracético- Cetavlon } \\ \text { EDTAT } & \text { Ácido Etilenodiamino Tetracético- Tergentol } \\ \text { EGTA } & \text { Ácido Etileno bis-Glicol Tetracético } \\ \text { MTAD } & \begin{array}{l}\text { Composto a base de isômero de tetraciclina, ácido e Tween } 80 \\ \text { MTT }\end{array} \\ \text { SDS } & \text { Brometo de 3-(4,5 dimetiltiazol-2il)-2,5-difenil-tetrazólio } \\ \text { NO } & \text { Docecil Sulfato de Sódio } \\ \text { ILf (g) } & \text { Força de rotação centrifuga (giros) } \\ \text { TNF- } \alpha & \text { Interleucina } \\ \text { FF-H } & \text { Fator de necrose tumoral alfa } \\ & \end{array}$




\section{LISTA DE SÍMBOLOS}

$\times 40$

Aumento de 40 vezes

$x 100$

Aumento de 100 vezes

$x 1000$

Aumento de 1000 vezes

$\mathrm{p}$

Nível de signifância 


\section{SUMÁRIO}

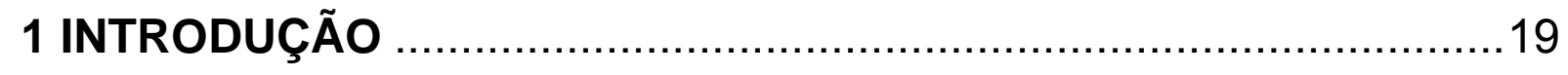

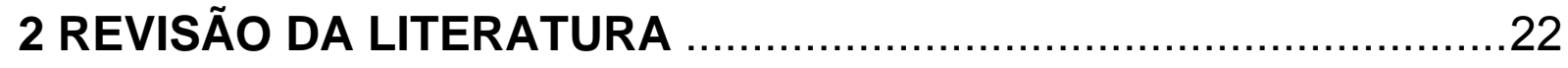

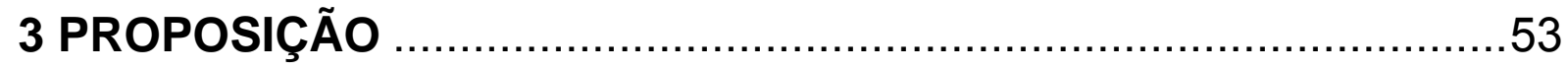

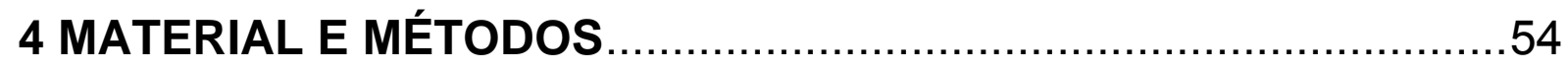

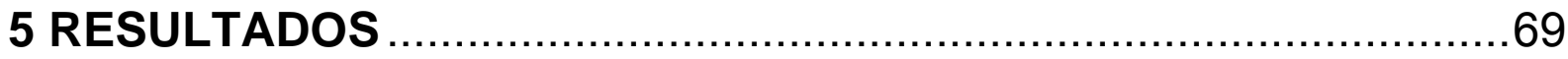

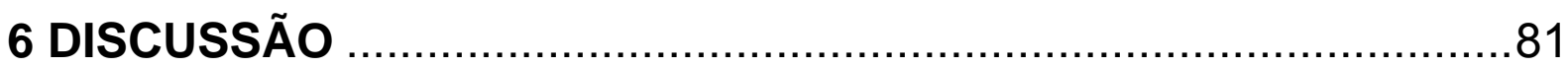

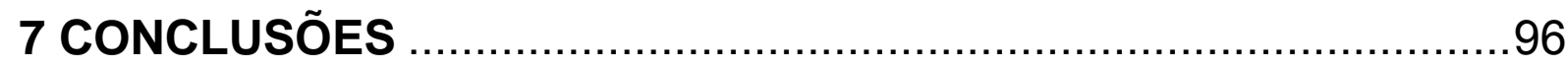

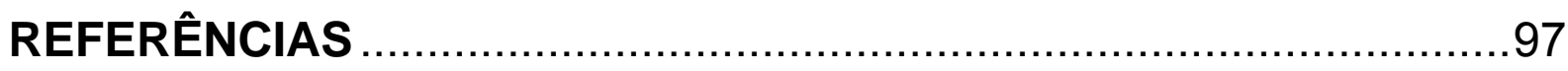

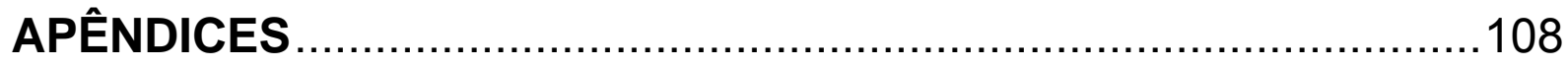

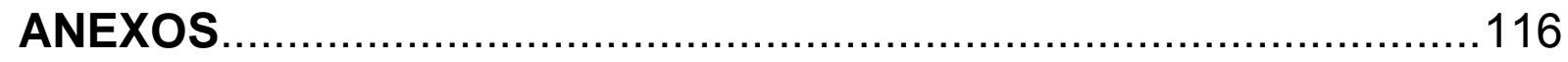




\section{INTRODUÇÃO}

O uso combinado de instrumentos endodônticos e substâncias químicas durante o preparo propiciam a modelagem, limpeza e desinfecção dos canais radiculares, favorecendo a ulterior obturação e contribuindo para o tão almejado sucesso endodôntico.

Porém, é justamente nesta fase que ocorre a formação do magma dentinário, a partir de raspas de dentina excisada, restos pulpares, restos bacterianos lisados e compostos químicos. A deposição desta película oblitera os túbulos dentinários, podendo comprometer a qualidade final do tratamento da seguinte forma:

1. Interfere na efetividade das substâncias químicas, não agindo em profundidade nos sistema de canais radiculares

2. Dificulta o poder de atuação da medicação intracanal

3. Reduz o embricamento do cimento obturador às paredes dentinárias e, assim, diminui o selamento apical

Conseqüentemente, a eliminação desta barreira mecânica irá produzir superfícies radiculares livres de sujidade, promoção de maior quantidade de túbulos dentinários expostos e dilatados, especialmente na porção apical do canal. 
Para isso, soluções dotadas de propriedades quelantes e desmineralizantes têm sido amplamente empregadas após o preparo químico-cirúrgico. Tanto o EDTA quanto o ácido cítrico comprovadamente reagem com os componentes inorgânicos do magma, proporcionado sua remoção e, por conseguinte aumentam a permeabilidade dentinária.

No entanto, informações a respeito do potencial irritativo destes irrigantes parece-nos pouco sedimentadas.

Em termos gerais, a compatibilidade biológica de uma determinada substância deve ser averiguada em níveis de complexidade, partindo-se dos estudos laboratoriais in vitro, experimentações em animais e, por último, testes de uso in vivo, principalmente quando estas mantêm íntimo contato com os tecidos do organismo.

Em particular na Endodontia, a instalação de agentes irritantes microbianos, mecânicos e químicos, isoladamente ou combinados, geram respostas inflamatórias periapicais de intensidade variável, dependendo do grau de agressão, e que podem prejudicar o processo de reparação.

Neste sentido, grande enfoque tem sido dado à atividade dos macrófagos na progressão das reações inflamatórias da região apical, notadamente na indução e perpetuação de lesões. A atividade dos macrófagos está relacionada tanto às respostas inflamatórias inespecíficas (fase aguda da inflamação) quanto aos quadros específicos (resposta imunológica envolvendo ativação de linfócitos) e ainda por se tratar de uma linhagem de células essencial para a reparação tecidual.

Acreditamos que, por meio de condições experimentais seja possível avaliarmos o comportamento do EDTA e do ácido cítrico sob as células do sistema imune, os macrófagos. 
Os resultados de biocompatibilidade apresentados neste trabalho poderão servir de subsídios ao endodontista ou mesmo ao clínico geral, para que a escolha de uma ou outra solução irrigadora seja a mais coerente e acertada, com vistas à integridade do elemento dental e tecidos circunvizinhos. 


\section{REVISÃO DA LITERATURA}

A compreensão de todo o ambiente endodôntico se inicia pelo conhecimento da área de atuação do endodontista, ou seja, a anatomia do canal radicular. Inicialmente, métodos mais simples baseados na infiltração de corante seguida de diafanização ou mesmo na moldagem do conduto radicular e, atualmente, estudos sofisticados que visam avaliar o espécime dental tridimensionalmente, por intermédio de micro-tomógrafo, têm sido propostos. Entretanto, há consenso sobre a diversidade e complexidade do sistema de canais radiculares (BJÖRNDAL et al., 1999; GOMES; RODRIGUES;TANCREDO, 1996; PETERS et al., 2000; VERTUCCI, 1984).

Por isso, torna-se imprescindível a utilização de substâncias químicas (principalmente o hipoclorito de sódio), durante o preparo químico-cirúrgico, pois além de favorecer a ação dos instrumentos, contribuem para a limpeza e desinfecção dos canais, mesmo de áreas inacessíveis aos instrumentos endodônticos.

No decorrer da instrumentação de canais radiculares evidenciou-se, em microscópio eletrônico de varredura, a presença de uma película heterogênea, de baixa densidade eletrônica e pouco aderida às paredes dentinárias, denominada magma dentinário. Sua espessura varia de 1 a $5 \mu \mathrm{m}$, principalmente em função do 
corte da dentina, quantidade e natureza do agente irrigante e tipo de instrumento utilizado. A instalação de bactérias ou seus sub-produtos fazem com que essa camada residual funcione como um reservatório de agentes irritantes no interior do canal radicular (PASHLEY, 1984).

O componente orgânico do magma é definido por proteínas coaguladas em função da denaturação da matriz colágena da dentina, restos de polpa vital ou necrótica, processos odontoblásticos, células sangüíneas e microorganismos. A parte inorgânica é oriunda do corte das estruturas dentais assim como de alguns contaminantes inorgânicos não-específicos (CZONSKOWSKY; WILSON; HOLSTEIN, 1990).

Complicações endodônticas como as reabsorções externas e lesões periapicais podem ser originadas da presença ou manutenção de bactérias alojadas profundamente nos túbulos dentinários, mantendo comunicação do canal radicular com o meio externo (BRÄNNSTRÖM, 1984).

Conscientes das limitações anatômicas e técnicas que englobam o tratamento endodôntico, a grande maioria dos pesquisadores suporta a necessidade de remoção do magma, objetivando aumento da permeabilidade, desinfecção radicular, efetividade da medicação intracanal e ainda, melhor vedamento do material obturador às paredes do canal.

Neste sentido, a revisão de literatura sugere a pesquisa de agentes químicos diversos, métodos de irrigação ultrassônica, irradiação laser que contribuem para a limpeza da camada residual de magma e conseqüentemente, o aumento da permeabilidade do complexo dentinário. 
Em particular, o EDTA (ácido etilenodiamino tetracético) e o ácido cítrico têmse mostrado efetivos na irrigação final de canais radiculares, melhorando a limpeza da superfície dentinária radicular.

O EDTA foi introduzido na Endodontia por Nygaard-Ostby (1957). Formado a partir de 4 grupamentos carboxílicos, este reage quimicamente com os íons metálicos da dentina, principalmente o cálcio, através de ligações covalentes e coordenadas, resultando na quelação da matriz dentinária e formação de compostos solúveis. Tal propriedade é auto-limitante devido a alteração do $\mathrm{pH}$ durante o processo de desmineralização da dentina até a saturação da solução (HÜLSMANN; HECKENDORFF; LENNON, 2003).

Observações em microscópio eletrônico de varredura de hemisseções radiculares tratadas com EDTAC (composto formado por EDTA e detergente catiônico Cetavlon, derivado da amônia quaternária) revelaram túbulos dentinários de aparência regular e diâmetro aumentado, sem que apresentassem qualquer indício de prolongamentos odontoblásticos, quando (GOLDBERG; ABRAMOVICH, 1977).

Mais tarde, Goldberg e Spielberg (1982) teceram relação entre o tempo de aplicação do EDTAC e a capacidade de limpeza da superfície dentinária, concluindo que as superfícies condicionadas por períodos de 15 e 30 minutos apresentaram remoção de debris e conseqüente exposição dos túbulos dentinários superiores ao período de 5 minutos.

Para Baumgartner e Mader (1987), embora o emprego de irrigantes como o hipoclorito de sódio e EDTA tenham prevenido a deposição de magma residual, o uso alternado de hipoclorito e EDTA durante a instrumentação de canais produziu 
significativa erosão da camada dentinária, às expensas da dissolução da dentina peritubular e intertubular, destacando o alargamento dos túbulos dentinários.

Da mesma forma, Peters e Barbakow (2000) evidenciaram menor formação de magma quando do uso combinado de hipoclorito de sódio e EDTA durante o trabalho radicular com limas rotatórias Light Speed e Profile, sendo que o sistema Light Speed mostrou significativamente menos sujidade no terço médio e apical dos canais.

Ainda Dogan e Çalt (2001) observaram redução na proporção cálcio/fósforo e na concentração de magnésio presentes na composição da dentina radicular quando da aplicação de EDTA seguido de hipoclorito de sódio.

A concentração, $\mathrm{o}$ pH e o tempo interferem substancialmente nas propriedades do EDTA. As soluções a $17 \%$ e tamponadas em $\mathrm{pH}$ neutro atingem efeito quelante ideal em 1 minuto de aplicação, pois com a dissolução dos cristais de hidroxiapatita, aumenta a quantidade de íons cálcio disponíveis. Por outro lado, o uso prolongado de EDTA pode acarretar em severa dissolução da dentina peritubular e intertubular (ÇALT; SERPER, 2002; SERPER; ÇALT, 2002).

Nesta ordem de idéias, o EDTA mostrou, estatisticamente, maior solubilização de componentes dentinários liofilizados em comparação à solução composta de isômero de tetraciclina (MTAD) e também ao hipoclorito de sódio (BELTZ; TORABINEJAD; POURESMAIL, 2003).

Além do EDTA amplamente empregado na forma líquida, diversas pastas contendo EDTA (Calcinase Slide ${ }^{\circledR}$, RC-Prep ${ }^{\circledR}$, Glyde File ${ }^{\circledR}$ ) têm mostrado boa capacidade quelante (HÜLSMANN; HECKENDORFF; SCHÄFERS, 2002).

Já o ácido cítrico teve seus estudos preliminares conduzidos por Loel (1975). A utilização de concentrações a $50 \%$ sob a dentina possibilitava a remoção de 
componentes inorgânicos e aumento das aberturas tubulares. Paralelamente, a aplicação desse ácido orgânico fraco proporcionava o condicionamento das superfícies radiculares em procedimentos periodontais, visando a regeneração e reinserção de fibras periodontais (HENNEQUIN; DOUILLARD, 1995).

Wayman et al. (1979) atestaram a capacidade do ácido cítrico, nas concentrações de 10\%, 25\% e 50\%, em extrair íons cálcio da estrutura dentinária radicular, sendo 7 a 9 vezes mais eficiente que o hipoclorito de sódio. Além disso, os autores acreditam que a utilização de ácido cítrico a 10\% e de hipoclorito de sódio a 2.5\% alcancem melhores resultados na remoção dos debris inorgânicos e orgânicos formados durante a instrumentação.

Avaliando-se a presença de sujidade e de magma residual em canais distais de molares inferiores, Baumgartner et al. (1984) puderam notar que superficialmente o NaOCL (hipoclorito de sódio) mostrou melhor limpeza de debris na região apical em comparação ao ácido cítrico, porém, em relação à camada de magma, as soluções de ácido cítrico demonstraram, isoladamente ou em combinação ao $\mathrm{NaOCL}$, resultados significativamente mais favoráveis na eliminação dessa película.

Alterações no $\mathrm{pH}$ das soluções de ácido cítrico interferem diretamente na ligação com o componente cálcio da estrutura dentinária e, deste modo, as observações de Hennequin, Pajot e Avignant (1994) associaram significativamente maior perda de cálcio às soluções de pH igual a 1.1. Os autores destacaram que, ao contrário do que imaginavam, a efetividade do ácido cítrico não aumenta em decorrência às altas concentrações, justamente pelo fato de que concentrações mais elevadas exerceram dissolução acentuada da fase mineral do magma, gerando precipitado de citrato de cálcio e soluções fosfatadas, e também induziram a re- 
precipitação de hidroxiapatita a partir de fosfoproteínas altamente fosforiladas (FFH), em conseqüência da exposição de matriz colágena da dentina.

À sua vez, Malheiros e Gavini (1998) testaram o potencial de descalcificação de fragmentos dentinários após imersão em soluções de ácido cítrico a $5 \%, 10 \%$, $15 \%, 25 \%$ por 15 minutos e 24 horas. Pelo processo de dupla pesagem, os resultados denotaram perda de massa significativamente maior no período de 24 horas (perda entre $28,3 \%$ a $39 \%$ em 24 horas contra $3 \%$ a 3,8\% em 15 minutos), notadamente nas concentrações de $10 \%$ e $15 \%$.

Mais recentemente, Haznedaroglu (2003) mostrou a interferência da concentração e pH do ácido cítrico na remoção de magma dentinário. Para isso, foram utilizadas concentrações a $5 \%, 10 \%, 15 \%, 25 \%$ e $50 \%$, valendo-se do pH próprio de cada solução, respectivamente: $1,9,1,8,1,5,1,1$ e também de soluções tamponadas em $\mathrm{pH} 6,0$. Amostras dentinárias foram imersas por 2 minutos nas soluções experimentais e, em seguida, observadas sob microscópio eletrônico de varredura. Para os grupos em que se utiliziraram baixas concentrações de ácido cítrico $(10 \%$ e $15 \%)$ e menor potencial hidrogeniônico $(\mathrm{pH})$, houve maior redução de magma dentinário, em contra-partida, as soluções mais concentradas (25\% e 50\%), independente do $\mathrm{pH}$, mostraram padrão semelhante de dissolução de magma, enfatizando a formação de cristais de citrato de cálcio aderidos às paredes dentinárias.

Outras pesquisas buscaram comparar o efeito de ambas soluções, EDTA e ácido cítrico, sob a dentina radicular.

Pelos achados de Yamada et al. (1983), a irrigação final de dentes após o preparo radicular com $10 \mathrm{~mL}$ de EDTA a $17 \%$ seguido de $10 \mathrm{~mL}$ de hipoclorito de sódio a 5,25\% alcançou melhor remoção de debris orgânicos e inorgânicos, 
revelando superfícies livres de sujidade e túbulos dentinários expostos. A utilização de EDTA em menor concentração não reproduziu resultados semelhantes. O ácido cítrico a $25 \%$ associado ao hipoclorito de sódio também mostrou efetividade, no entanto, observou-se precipitação de cristais aderidos às paredes do canal.

Analisando as reações químicas decorrentes do $\mathrm{NaOCl}$ a 5,25\% em conjunto com água oxigenada a 3\%, EDTA a $15 \%$ e ácido cítrico a 50\%, Baumgatner e lbay (1987) afirmaram que a combinação de irrigantes ideal para uso clínico deveria recair sobre o $\mathrm{NaOCl}$ e EDTA, pois demonstraram menor liberação de gases clorados (que são tóxicos) em comparação ao ácido cítrico.

Como bem salienta Gavini (1992), a limpeza dentinária é aumentada na dependência da natureza e do volume de agente irrigante empregado pós-preparo radicular, haja visto o índice de desobstrução de túbulos dentinários proporcionados pela irrigação final de compostos ácidos em conjunto ao hipoclorito de sódio, em ordem crescente: $6 \mathrm{~mL}$ de EDTA (17), $6 \mathrm{~mL}$ de ácido cítrico $(38,5), 3 \mathrm{~mL}$ de EDTA $(67,17), 3 \mathrm{~mL}$ de ácido cítrico $(77,33)$.

Com o propósito de investigar a ação de soluções irrigantes sobre a camada residual de magma, Garberoglio e Becce (1994) realizaram o preparo radicular com limas tipo $\mathrm{K}$ e NaOCL a $5 \%$ em dentes unirradiculares, e em seguida, os espécimes foram divididos em grupos, de acordo com o irrigante: NaOCL a $1 \%$, Tubulicid Plus ${ }^{\circledR}$ (solução comercial de EDTA a 3\%), EDTA a 17\%, ácido fosfórico a $24 \%$ e ácido cítrico a 10\%. Observações em microscópio eletrônico de varredura, dos terços médio e apical, apontaram diferenças significantes entre o grupo controle (NaOCL a $1 \%$ ) e os demais irrigantes. O hipoclorito de sódio manteve intensa camada de magma obliterando a superfície dentinária e a abertura dos túbulos, ao contrário das soluções desmineralizantes que, igualmente, garantiram ausência de magma. 
Ademais, os autores sugerem que os ácidos fosfórico e cítrico possam provocar efeitos deletérios aos tecidos da região periapical, em virtude do alto grau de descalcificação da matriz colágena da dentina e ampliação da abertura dos túbulos.

Os estudos de Gavini (1994) atribuíram melhor condição de limpeza da superfície apical para o EDTA a $17 \%$ e ácido cítrico a $25 \%$, independente do sistema de irrigação preconizado (pressurizado ou ultrassônico).

Yamaguchi et al. (1996) constataram resultados similares do EDTA e do ácido cítrico na extração de cálcio dos corpos de prova confeccionados com pó de dentina, bem como na inibição do crescimento de cepas bacterianas anaeróbias facultativas e anaeróbias estritas.

Tendo como fonte de variação a instrumentação do canal, manual ou mecânico-rotatória, e a irrigação final realizada com derivados de EDTA, como o Largal Ultra $^{\circledR}$ e Tubulicid Plus ${ }^{\circledR}$, e ácido cítrico a 50\%, Liolios et al. (1997) mostraram eficiente limpeza dentinária, independente da técnica de preparo preconizada, embora a instrumentação manual tenha proporcionado menor formação de magma. Quanto ao agente irrigante, aparentemente o ácido cítrico apresentou maior quantidade de debris, ainda que a espectofotometria de dispersão atômica revelasse a formação de cristais contendo cálcio e fósforo.

Pouco tempo depois, Caba e Gavini (1999) avaliaram a permeabilidade dentinária após a irrigação das superfícies radiculares com as soluções: Tergentol/Furacin, EDTA-T a $17 \%$ e ácido cítrico nas concentrações de 10\%, 15\% e 25\%. Como resultados, o ácido cítrico a $15 \%$ proporcionou elevada infiltração de corante e assim, aumento da permeabilidade dos terços médio e apical significativamente maior que os demais agentes analisados. 
Estabelecendo-se critérios de contagem de áreas da dentina radicular dos terços cervical, médio e apical para quantificação de túbulos dentinários livres de magma, Scelza, Antoniazzi e Scelza (2000) concluíram que a irrigação final realizada com EDTA-T (EDTA veiculado com Tergentol - detergente tensoativo aniônico) bem como o ácido cítrico a $10 \%$ produziram padrão dentinário estatisticamente melhor que o controle $(\mathrm{NaOCl}$ a $5,25 \%$ e peróxido de hidrogênio a $3 \%$ ) e, com relação aos terços radiculares, o segmento apical apresentou níveis de limpeza semelhantes ao médio, porém significativamente menor que o cervical.

Vislumbrando a influência de diferentes preparos radiculares (manual, rotatório com limas Profile 0.04, rotatório com limas MACXim e NT Engine File) e agentes irrigantes $(\mathrm{NaOCl}$ a $5 \%$, ácido cítrico a $19 \%$ seguido de $\mathrm{NaOCl}$ a $5 \%$ e EDTAC a $15 \%$ seguido de NaOCL a 5\%), Di Lenarda, Cadenaro e Sbaizero (2000) atribuíram melhor performance do uso alternado de ácido cítrico e hipoclorito de sódio, na redução de debris e na quantidade de túbulos não obliterados da região apical, que o EDTAC a $15 \%$ e $\mathrm{NaOCl}$. Nos grupos instrumentados pela técnica manual, o EDTAC produziu paredes significativamente mais limpas e para o sistema rotatório Profile 0.04, o ácido cítrico revelou melhor limpeza. Os autores suportaram que a aplicação de hipoclorito de sódio foi fundamental para a neutralização de qualquer traço dos agentes ácidos.

Mais tarde, Scelza, Teixeira e Scelza (2003) verificaram que as soluções de EDTA a $17 \%$ e ácido cítrico a $10 \%$ proporcionaram extração de cálcio da matriz dentinária de maneira semelhante, ao passo que a solução de EDTA associada ao tergentol (EDTA-T) produziu valores inferiores aos agentes citados. Pôde-se observar que a ação do ácido cítrico é tempo dependente, uma vez que a mensuração da concentração de cálcio aos 10 minutos foi estatisticamente maior em 
comparação ao período de 3 minutos. Já para o grupo EDTA não houve variação dos níveis de cálcio observados aos 3, 10 e 15 minutos.

Com o advento de novas tecnologias, Takeda et al. (1999) compararam o efeito de agentes desmineralizantes - entre eles o EDTA, ácido fosfórico e ácido cítrico -, e a irradiação laser com $\mathrm{CO}_{2}$ e Er:YAG, na capacidade de eliminação do magma residual. Ao final do experimento, concluiu-se que os ácidos, em geral, comportaram-se de maneira semelhante na limpeza e desobstrução de túbulos no terço médio do canal, evidenciando superfícies livres de sujidade, enquanto no terço apical notava-se a presença de alguns remanescentes dentinários. Por outro lado, a irradiação laser mostrou eficiência superior, em especial o laser Er:YAG que exibiu completa remoção de magma e também túbulos expostos e evidentes, mesmo que as superfícies radiculares tenham apresentado características bastante peculiares em função do laser empregado.

Além disso, a aplicação de laser Er:YAG bem como o tratamento dentinário pelo EDTAC promoveram a exposição dos túbulos dentinários, criando microretenções que melhoraram, sensivelmente, a adesão de cimentos obturadores resinosos às paredes do canal radicular, embora a irradiação laser tenha mostrado resultados superiores (PÉCORA et al., 2001).

Referindo-se ao selamento radicular, Villegas et al. (2002) preconizaram comparar o índice de obturação de canais radiculares acessórios (OPR), valendo-se do System B e sistema Obtura, mediante a irrigação final com as seguintes substâncias: nenhuma solução, água destilada, $\mathrm{NaOCl}$ a $6 \%$ e $\mathrm{NaOCl}$ a $6 \%$ associado ao EDTA a 15\%. O diâmetro dos canais avaliados eram superiores a 0.1 $\mathrm{mm}$ e, nesse mister, os índices OPR do EDTA associado ao $\mathrm{NaOCl}$ e $\mathrm{NaOCL}$ 
$(68,1 \%$ e $53,5 \%$, respectivamente) não foram estatisticamente significantes entre si, porém foram mais elevados que os demais grupos.

No ano seguinte, Clark-Holke et al. (2003), preocupados em avaliar a interferência da camada de magma na qualidade do selamento apical dispuseram de 2 grupos experimentais. Após o preparo radicular com limas K- Flex e solução de hipoclorito de sódio a 2,25\%, o Grupo 1 era submetido à irrigação final com EDTA a $17 \%$ e o Grupo 2 não recebia qualquer tratamento adicional. A obturação radicular foi realizada pela técnica de condensação lateral e cimento AH 26 e, a seguir, expostos à contaminação bacteriana anaeróbia. Nos grupos tratados com EDTA não houve infiltração bacteriana, ao passo que 60\% do Grupo 2 (sem remoção de magma) apresentaram contaminação positiva ao longo do experimento.

Quanto à ação antimicrobiana, a combinação do EDTA a 15\% e hipoclorito de sódio a $5 \%$, durante a fase de preparo de dentes portadores de mortificação pulpar, apresentou maior redução bacteriana que o hipoclorito de sódio a $0.5 \%$ e $5 \%$, sem contudo haver ausência total de contaminação em nenhum caso tratado (BYSTRÖM; SUNDQVIST, 1985).

Testes bacteriológicos apontaram redução de $72 \%$ do conteúdo bacteriano após o preparo e irrigação final com EDTA a $15 \%$ de dentes portadores de mortificação pulpar. Em contrapartida, o grupo controle composto por dentes submetidos somente ao preparo químico-cirúrgico registrou $35 \%$ de negatividade das culturas bacterianas (YOSHIDA et al., 1995).

Berutti, Marini e Angeretti (1997) evidenciaram a capacidade de desinfecção do $\mathrm{NaOCl}$ em conjunto ao EDTA a $10 \%$ em dentes inoculados com E. faecalis, observando túbulos dentinários livres de bactérias em profundidade média de 130 
$\mu \mathrm{m}$, sendo que no terço cervical e médio de em alguns espécimes houve completa ausência bacteriana.

Baseados nos trabalhos de Orstavik e Haapasalo (1990) que inocularam diversas espécies bacterianas em tubos de dentina bovina, o EDTA não produziu nenhuma ação bactericida.

Sob a mesma base metodológica, a aplicação de EDTA a 17\% mostrou-se ineficaz na eliminação de E. faecalis, todavia a associação de NaOCL a 1\% e EDTA a $17 \%$ despertou atividade desinfetante (HELING; CHANDLER, 1998).

Smith e Wayman (1986) alegaram que a concentração e o tempo de atuação do ácido cítrico interferiram na inativação de S. faecalis, posto que concentrações a $50 \%$, no período de 5 minutos, apresentaram $80 \%$ de destruição bacteriana, enquanto as soluções a $25 \%$ produziram efeito semelhante após 15 minutos.

Nikolaus, Wayman e Encinas (1988) confirmaram destruição de anaeróbios estritos, entre eles o B. melaninogenicus, B. fragilis, C. perfringens e P. anaerobius após inoculação por 5 e 15 minutos em ácido cítrico a 50\%.

Frente a doze espécies bacterianas (4 anaeróbias facultativas e 8 anaeróbias estritas) isoladas de canais infectados, tanto o EDTA quanto o ácido cítrico demonstraram alto potencial antibacteriano justificado pela presença de halo de inibição (YAMAGUCHI et al., 1996).

Diversos agentes irrigantes, entre eles o EDTA a 17\%, ácido cítrico a 10\%, hipoclorito de sódio (nas concentrações de 0,5\%, 2,5\%, 4,0\%) e clorexidina a 0,2\% e $2 \%$ imprimiram halo de inibição contra bactérias anaeróbias estritas $(P$. endodontalis, P. gingivalis, $P$ intermédia, $P$. nigrescens) e facultativas (E. faecalis, S. sobrinus, $S$. sangui, S. mutans), porém as soluções de $\mathrm{NaOCl}$ a $2,5 \%$ e $4,0 \%$ exerceram maior atividade bactericida em relação aos demais irrigantes (SIQUEIRA et al., 1998). 
No que tange o preparo radicular, durante a cinemática dos instrumentos associados às substâncias químicas, é irrefutável a extrusão de material para fora do ápice radicular. Em decorrência da técnica preconizada, essa extrusão ocorre em maior ou menor intensidade.

Acorde Al-Omari e Dummer (1995), as técnicas de preparo radicular envolvendo movimentos de penetração linear (step-back, step-back com desgaste anti-curvatura, double-flare) imprimiram maior extrusão de debris apicais que as técnicas rotacionais, sendo que os dentes preparados pela técnica da força balanceada evidenciaram menor formação de resíduos extra-apicais.

À sua vez, Ferraz et al. (2001) constataram que a instrumentação com limas de níquel-titânio acionadas a motor (Quantec 2000, Profile 0.4 e Pow-R) exibiram performance superior às técnicas manuais quanto a extrusão de debris e irrigantes apicais. Porém, o preparo manual valendo-se da força balanceada produziu resultados estatísticos semelhantes ao preparo rotatório.

Bergmans et al. (2001) relataram que, com o advento dos instrumentos rotatórios em níquel-titânio, o preparo radicular é aprimorado pelo máximo de eficiência de corte, menor transporte foraminal e diminuição da extrusão apical, pois geralmente tais instrumentos são utilizados com movimentos constantes de alargamento no sentido coroa-ápice.

Avaliando-se a quantidade de resíduos sólidos extra-apicais produzidos pela instrumentação rotatória de limas Quantec $L X$, segundo as técnicas de variação de conicidade e cérvico-apical, Deonízio (2001) e Deonízio, Gavini e Pantarolo (2002) apontaram resultados estatisticamente superiores nos canais modelados pela técnica rotatória cérvico-apical, evidenciando menor extrusão de debris. 
Neste contexto, embora a atuação dos procedimentos endodônticos esteja limitada ao interior do espaço radicular, as soluções ou medicamentos utilizados intracanal podem entrar em contato com os tecidos da região periapical e conseqüentemente causar injúrias, nos mais variados graus de intensidade (HAUMAN; LOVE, 2003).

Em virtude do uso inadvertido do hipoclorito de sódio durante o atendimento de uma paciente submetida à intervenção endodôntica do dente canino superior, Mehra, Clancy e Wu (2000) relataram o aparecimento de severos danos biológicos, destacando-se: dor intensa, equimose de mucosa, destruição de tecido conjuntivo, hematoma e edema facial.

Portanto, além das características físico-mecânicas e químicas inerentes aos produtos utilizados na prática odontológica, existe a preocupação em adequá-los quanto às propriedades biológicas, com vistas ao restabelecimento da saúde, função e estética dos elementos dentais e tecidos circunvizinhos.

Segundo o European Comitee for Standartization - EN 1441 (1996) e a International Organization for Standartization (ISO) - ISO 7405 e ISO 106 (1997), qualquer substância ou material dentário deve ser avaliado por testes de biocompatibilidade que são definidos como a capacidade desses produtos, uma vez aplicados no organismo, não ocasionarem reações adversas.

Na literatura destacam-se testes iniciais, testes secundários ou de toxicidade específica e por fim, testes clínicos de uso em humanos (SCHMALZ, 1994). Os testes iniciais estão alicerçados nos estudos in vitro, referindo-se principalmente na avaliação da citotoxicidade, que será abordada futuramente. Os testes secundários são marcados por experimentações em modelos animais e exemplificados por: implante em tecido subcutâneo (TORNECK, 1961), implante em tecido ósseo 
(BHAMBHANI; BOLANOS, 1993), irritação e ou sensibilização de mucosa (NUNES, 2002). E, dentre os testes de uso in vivo têm-se: irritação de mucosa oral, capeamento pulpar, pulpotomia (MESTRENER; HOLLAND; DEZAN, 2003; SCARANO et al., 2003) e também testes de uso endodôntico.

Ao longo dos anos, diversas metodologias têm sido propostas no que concerne o estudo dos materiais de uso endodôntico.

Em meados de 1930, Coolidge (1932) observou as reações teciduais em dentes de cães, na presença ou ausência de polpa radicular, quando preenchidos por diferentes agentes químicos (eugenol, fenol, cresol, cloramina T entre outros). A diversidade dos resultados histológicos foi atribuída à capacidade de penetração dos fármacos.

À sua vez, Nery, Souza e Holland (1974) objetivaram avaliar a reação inflamatória do coto pulpar e dos tecidos periapicais durante o preparo biomecânico em dentes de cães. Para isso, os dentes eram preparados com limas e os seguintes irrigantes: soro fisiológico, água destilada, solução saturada de hidróxido de sódio (água de cal), água oxigenada a 10 volumes, Tergentol, hipoclorito de sódio a 0,5\%, hipoclorito de sódio a 4,25\%, EDTAC, EDTA-ultra ${ }^{\circledR}$, Endo-prep ${ }^{\circledR}$ e EDTA. Ao término da instrumentação os dentes eram mantidos por 48 horas, sob diferentes condições: preenchidos com os irrigantes acima citados, secos com cones de papel ou irrigados com soro fisiológico seguido de selamento temporário. Os resultados histológicos comprovaram necrose nos cotos pulpares e instalação de processos inflamatórios, de moderado a severo, quando as soluções eram mantidas no interior do canal. As soluções menos irritantes foram o soro fisiológico, água destilada, água de cal, EDTA, EDTAC e EDTA-ultra ${ }^{\circledR}$. Nas demais situações experimentais houve menor agressão periapical e preservação da vitalidade pulpar. 
Pela análise histológica, Yeung e Clarke (1983) investigaram os efeitos pulpares decorrentes da aplicação tópica do ácido cítrico a $20 \%$ em superfícies radiculares de pré-molares de cães após períodos experimentais de 1, 7, 14, 28 e 56 dias. Os resultados apontaram que o condicionamento cementário do ácido cítrico não produziu nenhum indício de alterações nas polpas dentais.

Ao implantar tubos plásticos veiculados com variadas substâncias, entre elas o EDTAC, em subcutâneo de camundongos, Torneck (1961) afirmou que o potencial irritativo de uma droga intracanal é influenciado por fatores inerentes ao produto utilizado: tipo, concentração e natureza física da substância, volume da droga, forma de administração; e relacionados ao hospedeiro: diâmetro do forame apical, padrão histológico dos tecidos periodontais, tempo de exposição da droga aos tecidos, susceptibilidade do indivíduo à agressão.

Posteriormente, Yesiloy et al. (1995) determinaram os efeitos teciduais das soluções de $\mathrm{NaOCL}$ nas concentrações de 5,25\%; 2,5\% e 0,5\%; glucomato de clorexidina a $0,12 \%$; álcool, Peridex ${ }^{\circledR}$, Therasol ${ }^{\circledR}$ e solução salina após injeção no subcutâneo de porcos da Índia. As respostas inflamatórias mais severas e com formação de granuloma de corpo estranho ocorreram nos grupos inoculados com concentrações mais altas de $\mathrm{NaOCl}(5,25 \%$ e $2,5 \%)$ e do glucomato de clorexidina, decorridas 2 semanas.

Mais recentemente, Nunes (2002) analisou comparativamente os efeitos do $\mathrm{NaOCl}$ a $0,5 \%$, EDTA a $17 \%$, ácido cítrico a $25 \%$ e $50 \%$ sob feridas cirúrgicas em tecido subcutâneo de ratos. Em geral, o ácido cítrico retardou o processo de reparação tecidual, mostrando regressão do processo inflamatório agudo entre 14 e 28 dias, enquanto as demais soluções testadas evidenciaram diminuição do infiltrado inflamatório neutrofílico entre 7 e 14 dias. De acordo com a concentração 
do agente irrigante, o autor relata que o ácido cítrico a $50 \%$ proporcionou menor interferência na reparação tecidual que o ácido cítrico a $25 \%$, pelo fato que as soluções mais concentradas aceleram a coagulação protéica e diminuem sua difusão pelo tecido conjuntivo.

Attalla e Calvert (1969) avaliaram as propriedades irritativas de agentes irrigantes (EDTA, cloramina T, paramonoclorofenol canforado entre outros) pela instilação em conjuntiva ocular e injeção subcutânea dessas soluções em cães, comprovando alterações patológicas nesses tecidos.

Da mesma forma, Bombana et al. (1974) verificaram baixa resposta inflamatória em olho de coelho após a instilação de creme Endo-PTC neutralizado por hipoclorito de sódio a $0,5 \%$, seguido de irrigação com Tergentol/Furacin e medicação corticóide-antibiótica.

Com relação aos estudos in vivo, Harrison, Svec e Baumgartner (1978) visavam relacionar o tipo de solução utilizada durante o preparo radicular (solução salina, hipoclorito de sódio a 5,25\% e a combinação de hipoclorito de sódio a 5,25\% e água oxigenada a $3 \%$ ) e a presença de dor entre as sessões. Em $65,5 \%$ dos casos atendidos não houve manifestação de dor pós-operatória, 27,7\% relataram dor suave e apenas $6,7 \%$ denotaram dor severa. Contudo, nenhuma evidência estatística associou o grau da intensidade dolorosa, relatada pelos pacientes, aos agentes irrigantes empregados.

Neste mister, é inegável que as características biológicas de um material odontológico devam ser averiguadas de forma sistemática por uma sucessão de testes, desde o menos específico ao de maior especificidade. 
A cultura de órgãos, tecidos ou células constitui um dos primeiros métodos de toxicidade não específicos para detecção da biocompatibilidade ou tolerância tecidual de um determinado produto.

A determinação da viabilidade bem como da toxicidade celular podem ser interpretadas pela marcação celular com cromo radioativo (SPANGBERG, 1973), identificação do halo de inibição pelo contato direto material - célula (LEIRSKAR; HELGELAND 1981), mensuração do grau de destruição da monocamada celular, contagem de células por exclusão com azul de Trypan (MALHEIROS, 2000), entre outros.

De acordo com Kawahara, Yamagami e Nakamura (1968), é fundamental que as respostas biológicas dos diferentes materiais odontológicos sejam minuciosamente pesquisadas em laboratório, embora os resultados dos experimentos in vitro sejam diferentes dos resultados observados nos estudos in vivo. Todavia, o desenvolvimento e a sofisticação de técnicas, como o cultivo celular, contribui para a padronização biológica dos materiais dentários.

Para Spangberg (1969), o adequado meio de cultura e a implementação de soro fetal, seja bovino ou humano, propiciam o crescimento e manutenção da viabilidade dos componentes celulares sob condições experimentais em laboratório.

A confiabilidade científica dos estudos de citotoxicidade in vitro está relacionada à escolha da metodologia, sobretudo no componente celular empregado, tipo de contato célula - material, utilização de materiais na forma com que são propostos, critérios de avaliação bem estabelecidos e também na relevância clínica dos resultados (BROWNE; TYAS, 1979).

Em comparação às experimentações em animais ou aos estudos clínicos, o cultivo de células apresenta vantagens como simplicidade técnica, facilidade de 
reprodução dos resultados, controle das condições experimentais, metodologia bastante sensível, baixo custo, rapidez e respeito a bioética (HYAKUNA et al., 1989; SCHMALZ, 1994).

Nos testes de citotoxicidade, dois tipos de células são amplamente utilizados: linhagem de células permamentes - derivadas de coleções obtidas comercialmente - e linhagens primárias oriundas de explantes celulares ou teciduais e, portanto, estabelecidos em cada laboratório individualmente (FRESHNEY, 1990).

Schmalz e Sharaf (1988) compartilham a idéia que há uma tendência de que a linhagem celular permanente apresente maior sensibilidade que a linhagem primária.

Com o intuito de avaliar a compatibilidade de materiais aplicados na terapia endodôntica de dentes decíduos, Santos et al. (1996) identificaram padrão reacional semelhante das culturas de fibroblastos extraídos a partir do explante de polpa dentária humana e de fibroblastos NIH (National Institutes of Health) - 3T3, provenientes de linhagem permanente.

Engström e Spangberg (1967) compararam, em cultura de células HeLa, o efeito citotóxico do fenol, EDTA e ácido sulfúrico. Os resultados apontaram que, embora todas as sustâncias tenham causado danos celulares, o EDTA mostrou-se 4 vezes menos tóxico.

Analisando diferentes fármacos, entre esses o EDTA e hipoclorito de sódio, tanto por testes bacteriológicos quanto pela cultura de células, Masillamoni, Kettering e Torabinejad (1981) concluíram que é preciso estabelecer diluições das soluções para que sejam biologicamente compatíveis e ainda mantenham ação bactericida.

Com relação à metodologia de avaliação, a princípio deve-se optar por métodos mais simplificados baseados nos efeitos de membrana celular e índice de 
proliferação, tendo como exemplo a contagem celular direta. Como requinte técnico, a contagem pode ser combinada ao uso do corante azul de Trypan. As células não viáveis possibilitam a passagem do corante pela membrana celular, em contrapartida, as células vivas impedem a penetração do azul de Trypan, facilitando a identificação e contagem das células potencialmente ativas (SCHMALZ, 1994).

Os ensaios de citotoxicidade podem ser interpretados sob dois aspectos temporais: resposta celular imediata ou de curto prazo, associada às alterações da permeabilidade da membrana ou a algum dano específico do metabolismo das células; e resposta de longo prazo, implicando na retenção da capacidade de autorenovação e ou capacidade de sobrevivência celular em estado alterado, como por exemplo, a mutação genética. Enquanto os ensaios de curta duração calculam a proporção de células viáveis expostas a procedimentos traumáticos, os ensaios de longo prazo revelam a capacidade metabólica ou proliferativa das células após ou mesmo durante a exposição de agentes tóxicos (FRESHNEY, 1990).

O emprego de soluções irrigantes de diferentes concentrações, EDTA neutro (15\%, $1 \%$ e 0,1\%), EDTA pH 7,4 (17\%, 1\% e 0,1\%) e hipoclorito de sódio $(2,25 \%$, $1 \%$ e $0,1 \%$ ) em cultura de fibroblastos mostrou - pelo método de contagem celular adicionado à exclusão pelo azul de Trypan - que as soluções testadas apresentaram reações citotóxicas intensas, exceto as soluções a $0,1 \%$ (menos concentradas) que exibiram citotoxicidade moderada (KOULAOUZIDOU et al., 1999).

Malheiros (2000) observou o potencial citotóxico das soluções de EDTA a 17\% e ácido cítrico a 10\%, 15\% e 25\% em diluições de $0,1 \%$ e $0,5 \%$ em cultura de fibroblastos NIH 3T3, empregando ensaios de viabilidade celular por meio de células coradas pelo azul de Trypan. O estudo foi dividido em 2 etapas: curto e longo prazo 
de observação. No experimento de curto prazo, 3 placas de Petri foram plaqueadas com fibroblastos NIH 3T3 numa densidade de $2 \times 10^{4}$ contendo os diferentes irrigantes e observados após $0,6,12$ e 24 horas. Os resultados mostraram não haver diferenças estatísticas quanto à viabilidade celular entre as soluções de ácido cítrico e o controle. No entanto, as culturas de células mantidas com EDTA a 17\%, na diluição de 0,5\%, apresentaram morte celular após 6 horas. Observações em longo prazo (1, 3, 5 e 7 dias) apontaram que a proporção de células viáveis em contato com ácido cítrico a $10 \%$ e $15 \%$, tanto na diluição de $0,1 \%$ quanto de $0,5 \%$, foi semelhante ao grupo controle. O crescimento celular foi estatisticamente menor quando utilizados EDTA nas diluições de $0,1 \%$ e $0,5 \%$ e ácido cítrico a $25 \%$ na diluição de $0,5 \%$. Como conclusão, a solução de EDTA na diluição de $0,5 \%$ é intensamente citotóxica, provocando $100 \%$ de morte celular e as soluções de ácido cítrico a $10 \%$ e 15\%, independente da diluição avaliada, mostraram-se biologicamente compatíveis.

Nessa mesma linha de pesquisa, o comportamento de fibroblastos NIH 3T3 em contato com ácido cítrico a 10\% e EDTA-T (ácido etilenodiaminotetracético preparado com tergentol) nas diluições de $1 \%, 0,1 \%, 0,01 \%$ foi avaliado. No experimento de curta duração houve maior biocompatibilidade do ácido cítrico a $10 \%$, independente da diluição utilizada, enquanto o EDTA-T a $1 \%$ foi citotóxico após 24 horas. Em longo período de observação, ambas soluções na diluição de 1\% impediram o crescimento celular (SCELZA et al., 2001).

Tendo em vista a confrontação de diferentes componentes celulares (fibroblastos de ligamento periodontal humano, células epteliais humanas e células HeLa) e métodos de avaliação valendo-se da incorporação de BrdU, vermelho neutro e MTT (brometo de 3-(4,5 dimetiltiazol-2il)-2,5-difenil-tetrazólio), Lovschall, 
Eiskjaer e Arenholt-Bindslev (2002) comprovaram que tais fatores têm influência direta nos resultados de citotoxicidade do formaldeído, presente na formulação de muitos materiais odontológicos.

Pelos achados de Mossman (1983), o método de avaliação da toxicidade pelo uso do corante MTT é extremamente confiável, rápido e facilmente reproduzível, refletindo não somente o número de células em uma amostra, mas também o nível de sua atividade metabólica.

O MTT veiculado em solução salina apresenta coloração amarelafluorescente e é solúvel em água. Uma vez incorporados pelas células viáveis, a forma estrutural em anel do componente tetrazólio do MTT é quebrada pelas enzimas de-hidrogenases mitocondriais, gerando cristais insolúveis de formazina na cor azul escuro.

De sua parte, Collier e Pritsos (2003) indicaram que os processos oxidativos, bem como outras cadeias mitocondriais enzimáticas de elétrons possam ser responsáveis pela metabolização do MTT. O aumento da viabilidade celular, constatado pelo MTT, é inversamente proporcional à quantidade de oxigênio reativo liberado pelas células.

Para avaliação da toxicidade de alguns cimentos obturadores e retroobturadores em cultura de fibroblastos L929 e fibroblastos gengivais humanos, Osorio et al. (1998) empregaram o método de cristal violeta para determinação da proliferação celular e também o método MTT para verificar a atividade mitocondrial das células. Ambos experimentos sugeriram menor toxicidade dos cimentos retroobturadores, destacando o MTA (Mineral Trióxido Agregado), em comparação aos demais cimentos analisados. 
Referindo-se as soluções irrigadoras, ao investigar os efeitos do ácido cítrico $(0,01 \%$ a $1 \%)$ em cultura primária de fibroblastos pulpares humanos, Chan et al. (1999) concluíram que as amostras condicionadas com ácido cítrico a 0,5\% e 1,0\% no período de 2 horas exibiram morte celular em 25\% e 48\%, enquanto após 3 horas houve $77 \%$ de morte celular para o ácido cítrico a 1,0\%, justificada pela não redução do corante MTT e ainda pela perda da estrutura bipolar da célula, atrofia e danos na membrana celular. O autor afirma que os efeitos tóxicos do ácido cítrico foram provocados pela diminuição do $\mathrm{pH}$ do meio de cultura.

A busca de outros agentes irrigantes, que apresentassem concomitante eficácia na remoção da camada de magma dentinário e baixa toxicidade, levaram Serper et al. (2001) a pesquisar a Água Potencialmente Oxidativa (OPW- Oxidative Potencial Water) em dois momentos experimentais: análise da camada dentinária pela microscopia eletrônica de varredura e o efeito citotóxico em cultura de fibroblastos. Como conclusão, a OPW apresentou baixo índice de limpeza e menor exposição de túbulos dentinários no terço apical quando comparados à irrigação final com EDTA a $17 \%$ e hipoclorito de sódio a $5 \%$. No entanto, a OPW mostrou maior porcentagem de viabilidade celular, visualizada pelo MTT, que o hipoclorito de sódio e o EDTA, sendo que esse último foi intensamente citotóxico.

Pela utilização da cultura de fibroblastos L929, Zhang, Torabinejad e Li (2003) testaram o efeito tóxico do MTAD (composto formado pelo isômero de tretraciclina, ácido cítrico e Tween 80 ), eugenol, peróxido de uréia a $3 \%, \operatorname{REDTA}^{\circledR}$ (irrigante aquoso- Roth International Ltda), Peridex ${ }^{\circledR}$ (glucomato de clorexidina a $0,12 \%$ - Zila Pharmaceuticals), pasta a base de hidróxido de cálcio e hipoclorito de sódio a $5,25 \% ; 2,63 \% ; 1,31 \%$ e $0,66 \%$. Após 24 horas, a viabilidade celular e a dose inibitória em $50 \%$ foram determinadas pelo ensaio do MTT. O MTAD foi menos 
citotóxico que o eugenol, $\mathrm{NaOCL}$ a $5,25 \%$ e peróxido de hidrogênio a $3 \%$, embora o $\mathrm{NaOCI}$ nas concentrações mais baixas apresentasse maior biocompatibilidade.

Além de células fibroblásticas, outros componentes celulares presentes nos tecidos periapicais podem ser isolados e mantidos em cultura, destacando-se as células inflamatórias.

É fato que a reparação da região periapical ocorre na ausência de infecção e na dependência do grau de injúria dos tecidos lesados.

A presença de agentes irritantes, seja de natureza física, microbiana ou química, tem capacidade de alterar o processo reparacional. É inegável que os fenômenos inflamatórios são essenciais para a cronificação da inflamação aguda e posterior reparação e cura, mas em razão da intensidade da agressão, respostas inflamatórias instalam-se na mesma proporção da injúria, acarretando em retardo ou mesmo inibição da reparação.

A instalação de um quadro inflamatório agudo gera uma série de eventos celulares e vasculares desde vasodilatação, migração de células inflamatórias (neutrófilos, macrófagos) e liberação de mediadores, alguns dos quais desencadeiam dor.

Notadamente, a atividade dos macrófagos está relacionada ao mecanismo imunológico inato, pois são capazes de reconhecer, fagocitar, incluir e destruir células bacterianas sem que necessite a presença de antígenos específicos; imunidade inespecífica (fase aguda da inflamação); regulação e apresentação antígeno-anticorpo, envolvendo ativação de linfócitos na resposta imunológica específica; regulação da destruição e remodelação de tecido conjuntivo durante o

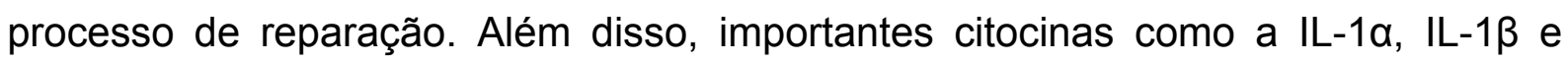


TNF- $\alpha$ contribuem no desencadeamento e regulação dos processos inflamatórios e são produzidas em larga escala por essas células (METZGER, 2000).

O padrão celular em lesões apicais (granulomas e cistos) de dentes submetidos a apicectomia mostrou elevada colonização de macrófagos, justificada pelo fato de participarem tanto da resposta imune específica - comandada pelos linfócitos T-indutores mediante secreção de fator ativador de macrófagos -, quanto na resposta inespecífica, caracterizada pelo recrutamento de outros macrófagos para o sítio inflamatório (KOPP; SCHWARTING, 1989).

A análise imuno-histoquímica de fragmentos de lesões apicais indicou a predominância de monócitos, macrófagos, linfócitos e outras células plasmáticas. Em alguns espécimes, os macrófagos apresentavam atividade fagocítica ativa e, em outros casos, sugeriram intensa síntese proteica, dada ao alto nível de mitocôndrias e retículo endoplasmático liso presentes no citoplasma (PIATELLI et al., 1991).

Para Akamine et al. (1994), houve um aumento marcante da população de macrófagos, em média, dez dias após a indução de lesões apicais em dentes de ratos. No decorrer de sessenta dias, a quantidade de células mononucleares, evidenciadas imuno-histoquimicamente pelo marcador celular ED1, atingiu estabilidade e, então, começou a diminuir.

Kawashima et al. (1996), ao utilizarem o mesmo modelo biológico, verificaram a predominância de células macrofágicas (células ED1 positivas) em lesões periapicais induzidas em dentes de ratos. No decorrer da evolução das lesões, os macrófagos localizados próximos aos vasos sanguíneos (forma estrutural pequena e arredondada) foram migrando em direção ao tecido conjuntivo (diversidade morfológica das células - formas ovalada, arredondada, espraiada, dentrítica ou 
poligonal). Entre 14 e 28 dias, as células estavam amplamente distribuídas e macrófagos típicos podiam ser observados no centro das lesões.

Baseados nos estudos in vitro, Metzger, Berg e Dotan (1997) observaram a interferência dos macrófagos ativados pelo LPS, ocasionando a interrupção do crescimento da colônia de fibroblastos. Pelos resultados apresentados, o autor sugere que os macrófagos desempenham papel primordial na progressão das reações inflamatórias periapicais, notadamente na indução e perpetuação de granulomas periapicais.

De acordo com Handel-Fernandez e Lopez (2000), a coleta de macrófagos peritoneais em roedores é amplamente difundida devido à facilidade técnica e obtenção de altas concentrações celulares (aproximadamente $3 \times 10^{6}$ células, contendo 50 a $70 \%$ de macrófagos por animal). Alguns agentes inflamatórios como o tioglicolato, caseína e proteases, quando previamente aplicados nos animais, mobilizam macrófagos circulantes do sangue para a cavidade peritoneal, aumentando o contingente de células disponíveis (entre 8 a $12 \times 10^{6}$ células, contendo $70 \%$ de macrófagos por animal).

Ao contrário de outras células, os monócitos e macrófagos dispõem de mecanismos de ativação relacionados à capacidade de aderência. Moléculas de adesão como o CD49a, CD49d, CD49e, integrinas e fibronectinas desempenham importante função nos estágios iniciais da interação célula-substrato. O processo de aderência dos macrófagos em substrato sólido é pH-dependente, intensificado pela alta concentração de soro e baixo pH do meio de cultura (GESSANI et al., 2000).

Para a obtenção da linhagem de macrófagos peritoneais, Fleit, Fleit e ZollaPazner (1984) apontaram vantagens na utilização de placas de cultura 
confeccionadas em poliestireno não-aderente e na manipulação e descolamento das células por raspagem ao invés dos processos químicos ou congelamento.

Com vistas ao estudo da citotoxicidade de materiais odontológicos, Santos, Jaeger e Guedes-Pinto (2000) desenvolveram um modelo experimental para o cultivo de macrófagos, utilizando a implantação de lamínulas de vidro no subcutâneo de ratos da linhagem Wistar. Após 7 dias, as lamínulas eram retiradas e transferidas para placas de Petri. Os macrófagos, aderidos às lamínulas, eram liberados pela tripsnização e, então, mantidos em meio de cultura sob condições controladas de temperatura e umidade, essenciais ao crescimento celular.

Jackson et al. (1994) sugeriram que o tratamento com EDTA para descolamento da monocamada de macrófagos aderidos às placas de cultura causam menor dano na membrana das células que o método de raspagem, mas não se pode descartar o risco de alterações e ou perda das estruturas de adesão, como também depressão do metabolismo celular.

Já Murphy e Newsholme (1999) afirmaram que os macrófagos em cultura não se dividem tão facilmente como as células de linhagens transformadas. Tal fato inviabilizaria a proliferação e subcultivo da linhagem.

Avaliando a biocompatibilidade de limalhas de amálgama contendo prata e estanho em cultura de macrófagos, Syrjänen, Nilner e Hensten-Pettersen (1986) comprovaram a eficiência dessas células no mecanismo de fagocitose, principalmente nos períodos iniciais ao contato célula - material analisado.

Outros estudos direcionados aos materiais restauradores comprovaram a liberação de citocinas, como a IL-6, decorrente da ação citotóxica de adesivos dentinários recém-polimerizados e expostos à cultura de macrófagos. Os resultados mostraram que o tempo de polimerização influenciou diretamente na viabilidade 
celular, detectada pelo método MTT, como nos níveis de IL-6 secretados (KOSTORYZ et al., 2003).

Com base nas pesquisas envolvendo os materiais endodônticos, Haglund et al. (2003) observaram o crescimento, morfologia e produção de citocinas (IL-1ß e IL6) frente a alguns materiais retro-obturadores, a partir da cultura de fibroblastos L929 e macrófagos RAW 264.7, provenientes de linhagem permanente de camundongos.

Para determinar a influência de cimentos endodônticos (AH 26, cimento de Grossman e cimento a base de óxido de zinco e eugenol) na capacidade de aderência de macrófagos peritoneais, concentrações de 2 a 4 × $10^{6}$ células foram plaquedas e mantidas em contato com os respectivos cimentos por 10, 20 e 30 minutos. Ao final dos tempos experimentais, alíquotas de $10 \mathrm{uL}$ das células em suspensão (não aderentes) foram contadas em câmara de Neubauer, determinando o índice de aderência, sendo que o AH 26 mostrou-se significativamente menos citotóxico (SADEGHEIN; BOLHARI; SARAFNEJAD, 2001).

Sob o mesmo aspecto, Mendes et al. (2003) analisaram a viabilidade celular, capacidade de aderência, fagocitose, produção de IL-12 e NO (óxido nítrico) de macrófagos coletados na cavidade peritoneal de camundongos e mantidos na presença de dois cimentos obturadores. Os resultados apontaram efeitos inibitórios na produção de NO e na capacidade de fagocitose, independente do cimento testado e de seu tempo de presa.

Sjögren, Sundqvist e Lerner (1998) mostraram a liberação de cálcio em cultura óssea de camundongos que foram expostas ao meio de cultura de macrófagos condicionados por partículas de guta-percha. O estímulo de reabsorção óssea - justificado pela liberação de íons cálcio - foi inibido após a colocação de receptor de proteína contra interleucina-1 e soro anti-interleucina 1-a. Portanto, os 
achados desse estudo comprovam que os macrófagos estimulados pela guta-percha produziram IL-1- $\alpha$ e, essa citocina pode estar envolvida no processo de reabsorção óssea.

Além dos fatores externos já relatados, Lara et al. (2003) provaram que componentes proteicos da dentina são capazes de promover migração leucocitária de maneira dose e tempo-dependente e também desencadear aumento da concentração de $\mathrm{NO}, \mathrm{H}_{2} \mathrm{O}_{2}$ e TNF- $\alpha$. Pelos dados obtidos nas experimentações in vivo (injeção subcutânea) e in vitro (cultura de macrógafos peritoneais) em camundongos, o autor afirma que a dentina pode induzir respostas inflamatórias e também pode influenciar na patogenia das reabsorções radiculares inflamatórias.

Como foi salientado anteriormente, durante o preparo do canal ocorre a formação de magma dentinário - constituído de restos orgânicos e inorgânicos dentinários, componentes bacterianos e resquícios de substância irrigadoras - que inadvertidamente atingem a região apical, contribuindo assim para a instalação de processos inflamatórios.

Contudo, a literatura é pouco abrangente quanto à ação biológica das soluções irrigantes exercidas sob as células inflamatórias.

O extravazamento de EDTA para a região apical poderia alterar o mecanismo de atuação das células macrofágicas, visto que as soluções de EDTA mantidas em contato com macrófagos em cultura inibiram a ligação de peptídeos intestinais vasoativos (VIP). Concentrações de EDTA a $5 \mathrm{mM}$ e $10 \mathrm{mM}$ provocaram, respectivamente, $55 \%$ e $72 \%$ de redução da ligação VIP, um dos neuropeptídeos responsáveis pela modulação das respostas imunes periapicais (SEGURA et al., 1996). 
Segura et al. (1997) verificaram a redução da capacidade de aderência dos macrófagos quando em contato com soluções de EDTA em diferentes concentrações e períodos de tempo. Suspensão de macrófagos obtidos de amostras sanguíneas de ratos foram colocadas em contato com soluções de EDTA nas concentrações de $5 \mathrm{mM}, 100 \mathrm{mM}$ e $300 \mathrm{mM}$ e após 5,15 e 30 minutos foram realizadas contagens em câmara de Neubauer das células não aderidas. Os resultados mostraram que o máximo de inibição da capacidade de aderência dos macrófagos ocorreu nos períodos de 15 e 30 minutos nas diferentes concentrações e ainda concentrações maiores de EDTA exibiram efeitos inibitórios mais significativos. Com base nos dados obtidos, os autores sugeriram que o EDTA pode auxiliar positivamente diminuindo as respostas inflamatórias teciduais, uma vez que inibe a capacidade de aderência dos macrófagos, essencial no processo de fagocitose durante o quadro inflamatório. Por outro lado, a influência do EDTA sob a capacidade de aderência dos macrófagos pode interferir negativamente, pois a diminuição da atividade fagocitária possibilita a permanência de debris na região periapical, comprometendo o processo reparacional ou mesmo levando a cronicidade.

Seguindo a metodologia proposta por Segura et al. (1997), Segura-Egea et al. (2003) avaliaram a capacidade de aderência de macrófagos frente a soluções quelantes, como o EDTA e EGTA (ácido etileno glicol-bis-( $\beta$-aminoetil éter)$\mathrm{N}, \mathrm{N}, \mathrm{N}^{\prime}, \mathrm{N}^{\prime}$ - tetracético), após períodos de 5, 15 e 30 minutos. Para tanto, $20 \mu \mathrm{L}$ das soluções, nas concentrações finais entre $2 \mathrm{mM}$ e $300 \mathrm{mM}$, foram adicionadas em tubos Eppendorf contendo 2 a $4 \times 10^{6}$ células. $\mathrm{O}$ índice de aderência celular (Al) foi calculado pela fórmula: $\mathrm{Al}=100-$ (macrófagos não aderentes por $\mathrm{mL} /$ macrófagos iniciais por $\mathrm{mL}) \times 100$. Os resultados indicaram efeitos da $1 / 2$ da inibição máxima 
$\left(\mathrm{IC}_{50}\right)$ de 202 +/- 32 mM para o EGTA e 185 +/- 22 mM para o EDTA, propondo que o EDTA reduz mais intensamente a capacidade de aderência de macrófagos e, por conseguinte, pode provocar alterações nas respostas imunológicas e inflamatórias dos tecidos periapicais.

Constatada a confiabilidade científica das técnicas de cultivo celular, bem como a necessidade por informações a respeito de procedimentos, materiais e soluções químicas menos traumáticos e lesivos aos tecidos periapicais propusemos estudar in vitro a toxicidade do EDTA e ácido cítrico em cultura de macrófagos peritoneais. 


\section{PROPOSIÇÃO}

Diante do exposto, o presente estudo objetivou analisar comparativamente a citotoxicidade imediata (curto prazo) e tardia (médio prazo) do EDTA a 17\% e do ácido cítrico a $15 \%$ quando aplicados em cultura de macrófagos peritoneais residentes, provenientes de camundongos Swiss, utilizando ensaios de viabilidade celular pelo método MTT. 


\section{MATERIAL E MÉTODOS}

Obedecendo aos critérios e aprovação do Comitê de Ética em Experimentação Animal sob o protocolo n. ${ }^{0}$ 19/2003 (Anexo A), foram utilizados macrófagos peritoneais residentes obtidos de 32 camundongos Swiss machos, de 8 a 12 semanas de idade, provenientes do Biotério do Conjunto das Químicas da Universidade de São Paulo e mantidos em gaioleiros sob regime ad libitum de água e ração comercial até o início do experimento.

\subsection{Material}

- Meio de cultura celular Mc Coy's 5A estéril (Sigma)

- Soro fetal bovino estéril (Sigma)

- Solução antibiótica (penicilina/ streptomicina) (Sigma)

- Água tri-destilada tipo milli-Q

- Becker $500 \mathrm{~mL}$ (Vidrolabor)

- Proveta $500 \mathrm{~mL}$ (Vidrolabor)

- Funil de vidro (Vidrolabor)

- Analisador de pH (Denver Instrument) 
- Solução tampão $\mathrm{HCl}$ a $1 \mathrm{M}$

- Solução tampão $\mathrm{NaOH}$ a 1 M

- Filtro Millipore

- Membrana Millipore de 0,22 $\mu$

- Álcool iodado

- Cloridrato de xilazina (Rompum ${ }^{\circledR}$ )

- Cloridrato de ketamina (Francotar $\left.{ }^{\circledR}\right)$

- Placa de parafina

- Tesoura reta de ponta romba

- Tesoura reta de ponta fina

- Pinça dente de rato

- Pinça clínica

- Capela de fluxo laminar (VECO - Campinas, SP, Brasil)

- Banho Maria (Fanem)

- Tubo Falcon estéril $15 \mathrm{~mL}$ (Costar)

- Tubo Falcon estéril $50 \mathrm{~mL}$ (Costar)

- Seringa plástica descartável e estéril 10 mL (Rymco)

- Agulha descartável e estéril $25 \times 7$ mm (BD)

- Estufa com controle de temperatura/ pressão de $\mathrm{CO}_{2}$ (Thermo Forma)

- Pipeta de transferência plástica descartável e estéril 3,0 mL (Falcon)

- Ponteira plástica estéril até $200 \mu \mathrm{l}$ (Costar)

- Ponteira plástica estéril até $1000 \mu \mathrm{L}$ (Costar)

- Pipeta 2 a $20 \mu \mathrm{L}$ (Nichiryo)

- Pipeta 20 a $200 \mu \mathrm{L}$ (Nichiryo)

- Pipeta 100 a $1000 \mu \mathrm{L}$ (Nichiryo) 
- Centrífuga 5810 R para tubos Eppendorf (Eppendorf)

- Microscópio invertido de fase (Nikon)

- Microscópio óptico (Olympus)

- Tubo de ensaio (Costar)

- Azul de Trypan a 0,5\% (Sigma)

- Câmara de Neubauer (Brand)

- Placa de cultura celular aderente - 24 poços (Costar)

- Lamínula de vidro esférica $13 \mathrm{~mm}$ de diâmetro (Glass Técnica)

- Ácido cítrico a 15\% (Fórmula e Ação Ltda., São Paulo)

- EDTA a 17\% (Fórmula e Ação Ltda., São Paulo)

- Meio Mc Coy's 5A (Sigma)

- Soro fetal bovino (Cultilab)

- Corante MTT (Sigma)

- Solução SDS (Sigma)

- Citocentrífuga (Incibrás)

- Corante May Grunwald - Giemsa, modificado por Rosenfeld

- Lâmina de vidro (Glass Técnica)

- Lamínula de vidro quadrada 20 mm (Glass Técnica)

- Leitora de ELISA 550 nm (Bio-Tek Instruments)

- Microcomputador (Pentil IV) 


\subsection{Métodos}

\subsubsection{Preparo das soluções}

As soluções utilizadas neste experimento foram manipuladas no laboratório de Hematologia Clínica da Faculdade de Ciências Farmacêuticas da Universidade de São Paulo. Estas foram esterilizadas por um processo de filtragem, utilizando-se membranas milipore 0,22 $\mu$ em ambiente asséptico (capela de fluxo laminar).

O meio Mc Coy's 5A e a solução de SDS foram transferidas para frascos de vidro autoclavados e armazenados sob refrigeração $0^{\circ} \mathrm{C}$ e à temperatura ambiente, respectivamente. A solução de MTT foi aliquotada em tubos Eppendorf de 2,0 mL, embalados em papel escuro para protegê-los da luminosidade e mantidos sob refrigeração $\mathrm{a}-70^{\circ} \mathrm{C}$.

O EDTA a 17\% e ácido cítrico a 15\% foram adquiridos do laboratório Fórmula e Ação Ltda.

\subsubsection{Coleta de macrófagos peritoneais residentes}

Os animais foram anestesiados com injeção intra-muscular de 0,01 mL de cloridrato de xilazina e 0,03 $\mathrm{mL}$ de cloridrato de ketamina, sacrificados pela secção dos vasos sanguíneos cervicais e exsanguinados. Estes eram colocados em potes 
contendo álcool iodado e levados imediatamente para a capela de fluxo laminar, dando prosseguimento à coleta (Figura 4.1).

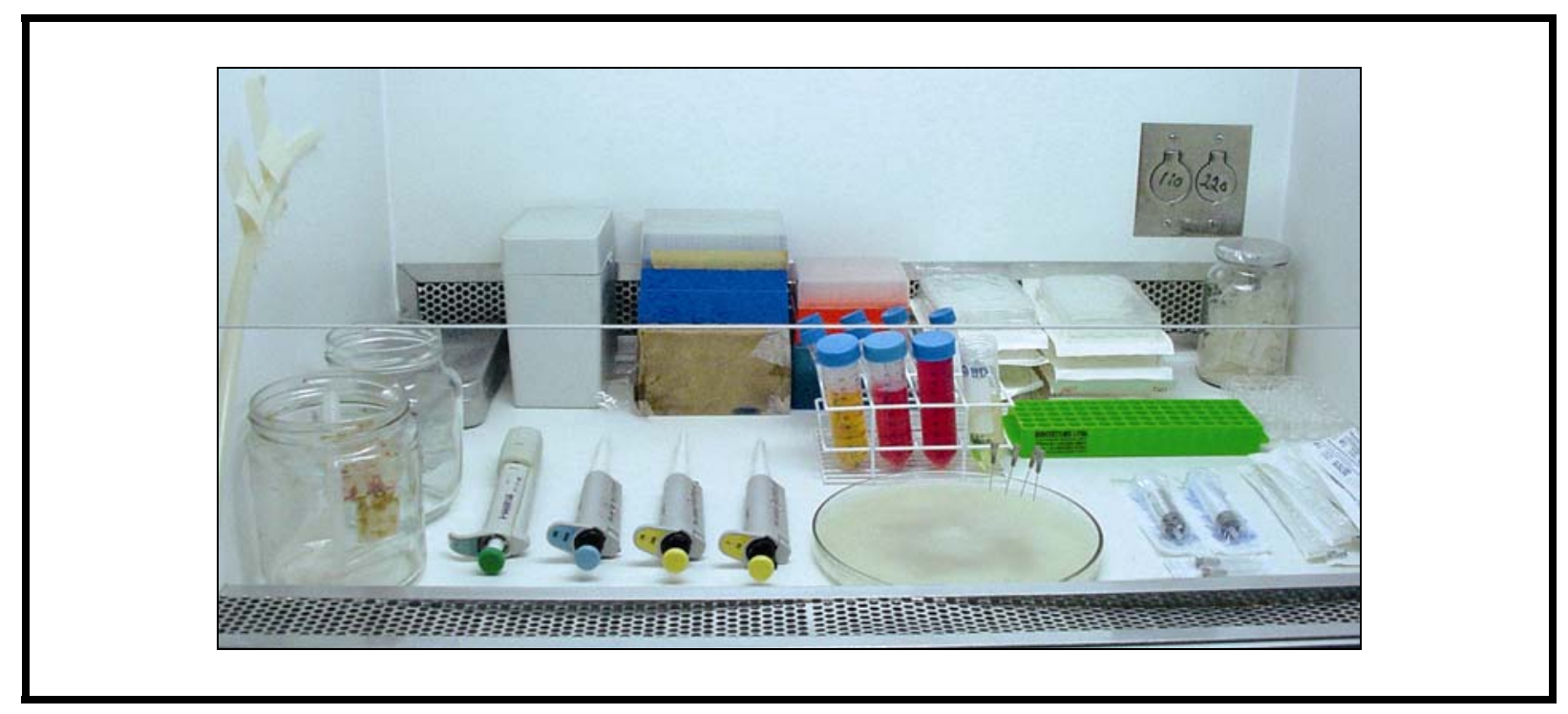

Figura 4.1 - Capela de fluxo laminar

A seguir, os animais foram imobilizados em placas de parafina na posição de decúbito dorsal. Com o auxílio de pinça mosquito era feita a apreensão da pele, cerca de $1 \mathrm{~cm}$ acima do órgão genital e, neste ponto era feita a administração intraperitoneal de $7 \mathrm{~mL}$ de meio de cultura celular estéril e gelado (Mc Coy's 5A enriquecido com $10 \%$ de soro fetal bovino e 1\% de solução antibiótica) utilizando seringa plástica de $10 \mathrm{~mL}$ e agulha $25 \times 7 \mathrm{~mm}$ (Figura 4.2A).

A região abdominal era massageada com os dedos indicador e polegar (80 ciclos de massagem) para estimulação das células macrofágicas residentes (Figura $4.2 B)$. 


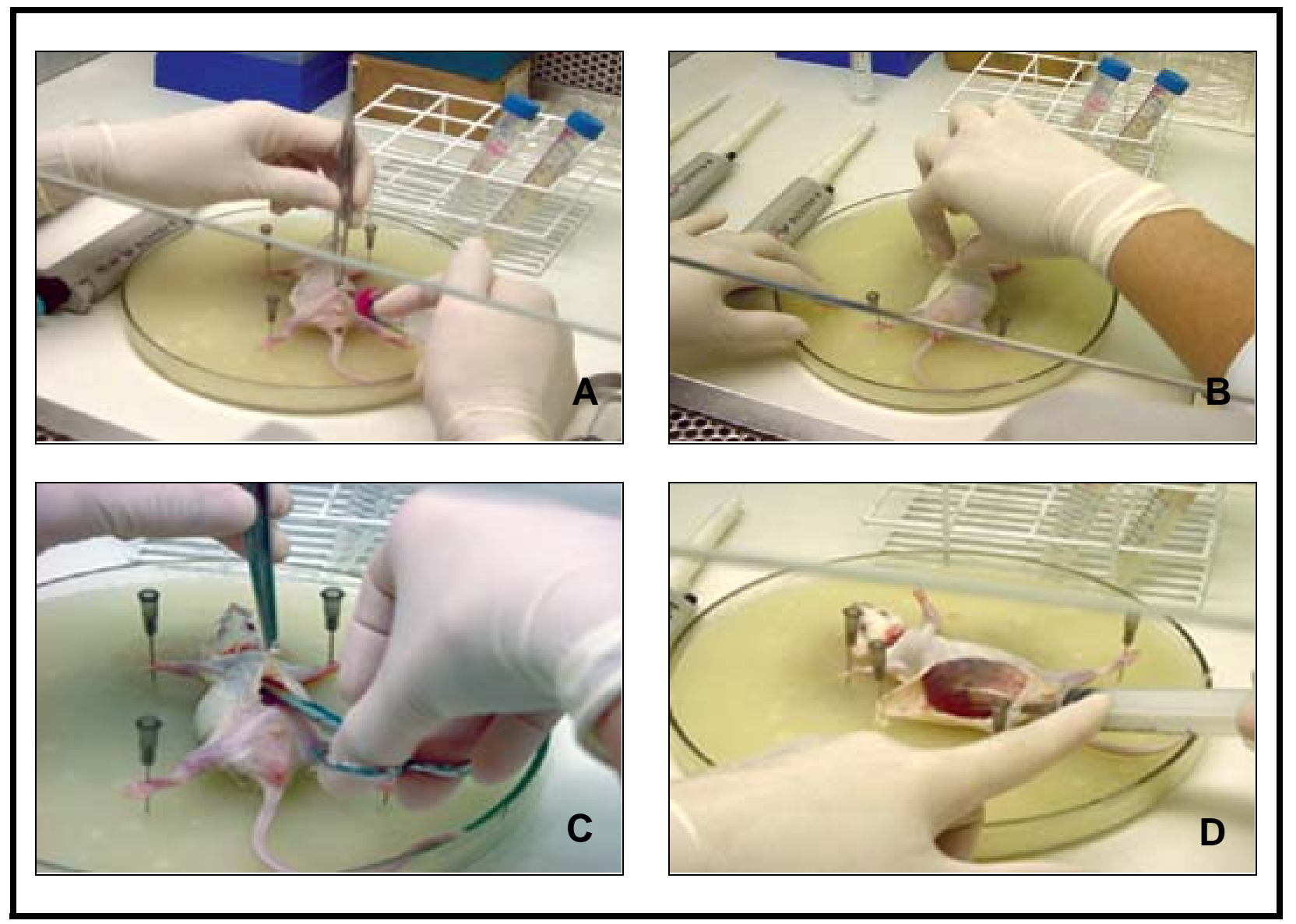

Figura 4.2A - Punção e injeção do meio de cultura. Figura 4.2B - Massagem da região abdominal. Figura 4.2C - Corte e divulsão da pele e tecido subcutâneo. Figura 4.2D - Exposição da membrana peritoneal, destacando o exsudato formado

No local da punção era feito um corte com tesoura de ponta fina de aproximadamente $1 \mathrm{~cm}$ e, tanto a pele quanto o tecido subcutâneo eram divulsionados com tesoura de ponta romba para exposição da membrana peritoneal do animal (Figuras 4.2C; 4.2D).

O exsudato celular formado na cavidade abdominal era aspirado com seringa plástica e agulha. O conteúdo coletado era transferido para tubos Falcon estéreis de $15 \mathrm{~mL}$ e mantidos em banho de gelo por um período inferior a 1 hora (Figuras 4.3A, $4.3 B, 4.3 C)$. 


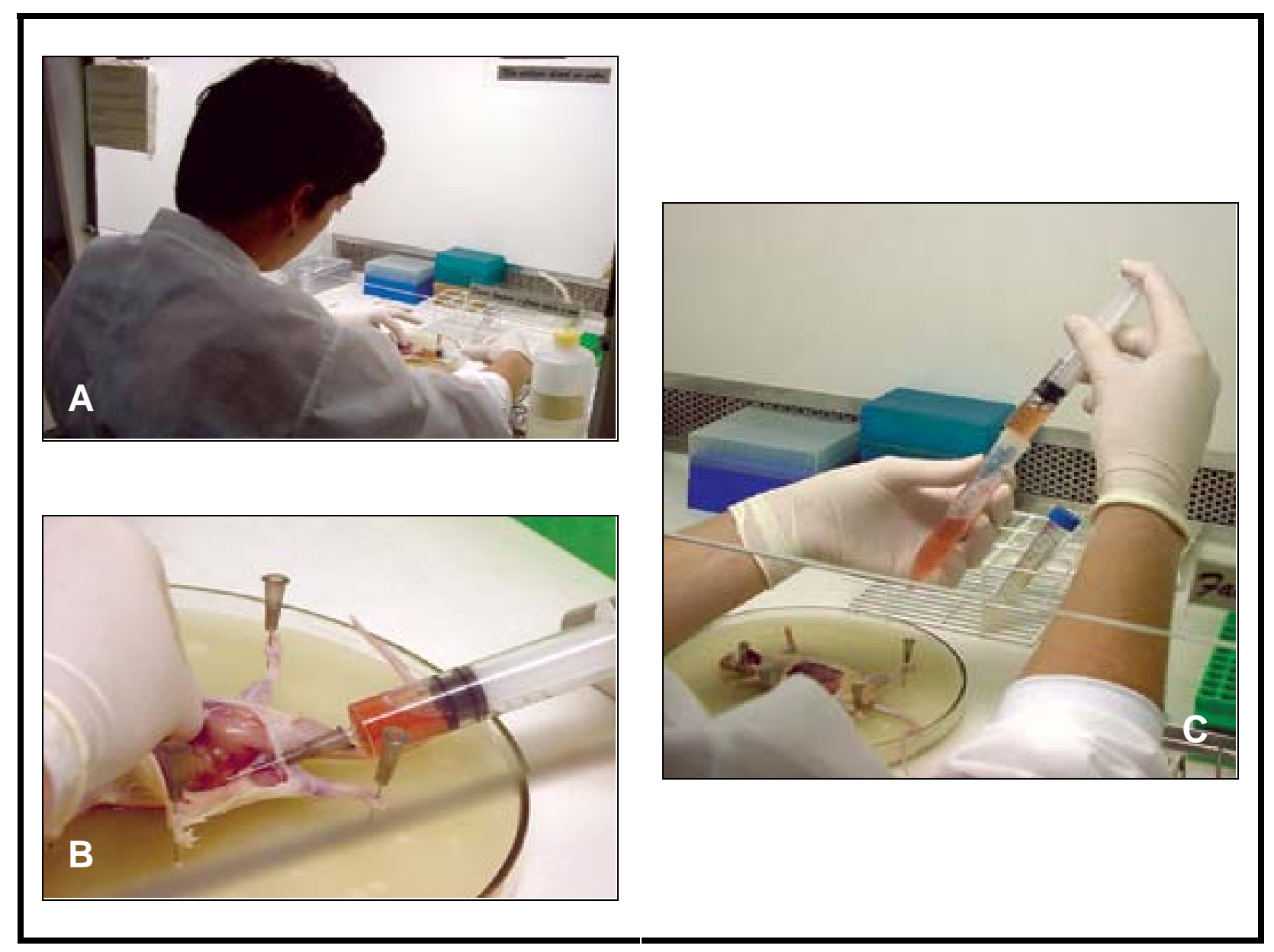

Figura 4.3A - Aspiração do exsudato peritoneal. Figura 4.3B - Aspiração do exsudato peritoneal em detalhe. Figura 4.3C - Transferência do exsudato peritoneal para tubo Falcon

Este procedimento foi semelhante para todos os animais $(n=32)$ utilizados neste estudo.

Finalizada a coleta, os tubos Falcon eram levados para centrifugação (Figura 4.4) numa temperatura de $4^{\circ} \mathrm{C}, 453 \mathrm{rcf}(\mathrm{g})$ por 10 minutos. O sobrenadante era aspirado com seringas Pasteur e o sedimento celular resultante da centrifugação era ressuspendido em $5 \mathrm{~mL}$ de meio Mc Coy's 5A gelado.

Este processo foi repetido por 3 vezes. 

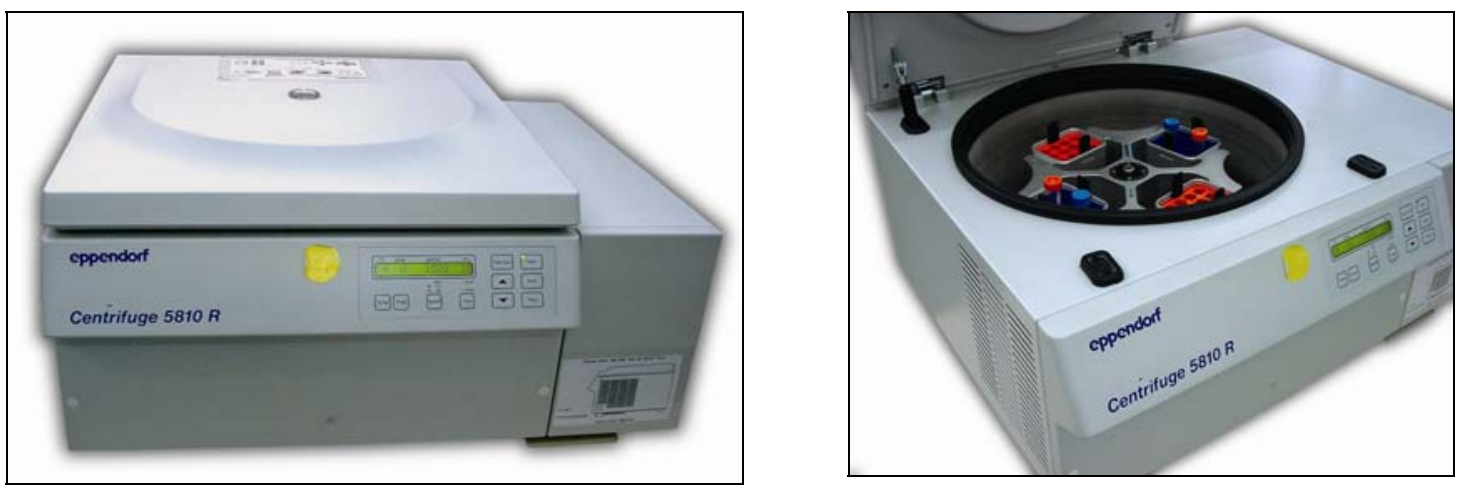

Figura 4.4 - Centrífuga

4.2.3 Contagem celular e identificação da porcentagem de macrófagos

Após o último ciclo de centrifugação, realizou-se a homogeinzação dos precipitados celulares, formando um pool de células, que foram ressuspensas em 20 $\mathrm{mL}$ de meio Mc Coy's 5A gelado.

Alíquota de $20 \mu \mathrm{L}$ desta suspensão foi adicionada a $380 \mu \mathrm{L}$ de Azul de Trypan a 0,5\% e submetida à contagem em câmara de Neubauer sob microscópio óptico (100 vezes de aumento), pela seguinte fórmula:
N. ${ }^{\circ}$ células $/ \mathrm{mm}^{3}=$
N. ${ }^{\circ}$ total de células viáveis contadas
Diluição utilizada x Volume contado na câmara

A avaliação e identificação dos tipos celulares, mais precisamente macrófagos, contidos na amostra total coletada (pool celular) foi realizada pela análise morfológica. 
Para isso, $20 \mu \mathrm{L}$ desta amostra foi submetida a citocentrifugação por 5 minutos, 193 rcf (g) a temperatura ambiente.

As lâminas do citocentrifugado foram coradas pela técnica May-GrunwaldGiensa, modificada por Rosenfeld e observadas em microscópio óptico (40 e 100 vezes de aumento), estabelecendo a porcentagem de macrófagos presentes pela fórmula:

$$
\text { Porcentagem de macrófagos }=\frac{\mathrm{N} \cdot{ }^{\circ} \text { macrófagos contados } / \mathrm{mL} \times 100}{\mathrm{~N} .{ }^{\circ} \text { total de células } / \mathrm{mL}}
$$

A população de macrófagos compunha em média 95\% do total celular obtido.

\subsubsection{Plaqueamento celular}

As suspensões celulares foram distribuídas em placas de cultura para células aderentes de 24 poços, numa concentração de $5 \times 10^{5}$ células e completadas com o meio de cultivo específico para cada grupo experimental, perfazendo um total de 1,0 $\mathrm{mL}$ por poço.

Para cada tempo de observação utilizou-se uma placa de cultura, na qual foram plaqueadas amostras em triplicatas para as diferentes soluções testadas, possibilitando a avaliação da viabilidade celular.

Em dois outros poços foram colocadas lamínulas de vidro de $13 \mathrm{~mm}$ de diâmetro, que igualmente eram preenchidos com as suspensões de células e meio 
de cultura para os diferentes grupos e tempos experimentais. Ao final de cada tempo, as lamínulas eram removidas e coradas pela técnica May-Grunwald-Giensa e observadas em microscópio óptico para análise morfológica das estruturas celulares.

As placas de cultura foram mantidas em estufa a $37^{\circ} \mathrm{C}$, em atmosfera úmida contendo $95 \%$ de ar e $5 \%$ de $\mathrm{CO}_{2}$.

Todo o procedimento de coleta e processamento das amostras foi realizado sob condições assépticas, em capela de fluxo laminar.

\subsubsection{Grupos experimentais}

- Grupo I - Controle

Meio de cultura (Mc Coy's 5A estéril)

- $\quad$ Grupo II - EDTA a $17 \%$

Meio de cultura condicionado com $0,5 \%$ de EDTA a $17 \%$

- $\quad$ Grupo III - Ácido cítrico a 15\%

Meio de cultura condicionado com 0,5\% de ácido cítrico a 15\%

\subsubsection{Citotoxicidade celular de curto prazo}

Placas de cultura celular (24 poços) foram aliquotadas com $5 \times 10^{5}$ células e completadas com meio de cultivo, mantidos previamente em banho-maria, de acordo 
com os grupos experimentais acima relatados, obtendo um volume final de $1,0 \mathrm{~mL}$ (Figura 4.5).

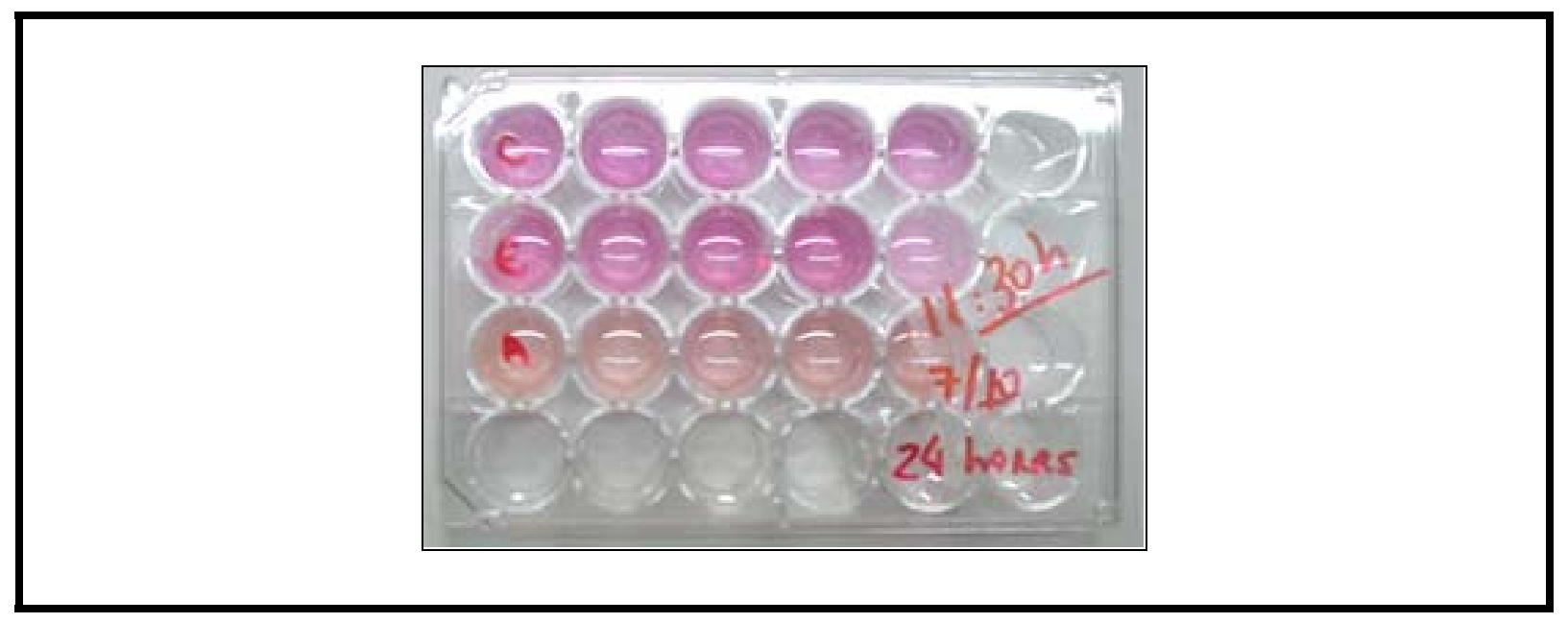

Figura 4.5 - Placa de cultura dos grupos experimentais

Os tempos de observação do ensaio de curto prazo foram: 0, 6, 12 e 24 horas.

Ao término de cada período, determinou-se a viabilidade celular pelo método MTT.

Quantidades de $50 \mu \mathrm{L}$ de substrato MTT, diluído em água tri-destilada na concentração de $5 \mathrm{mg} / \mathrm{mL}$, foram adicionadas aos poços das placas, tomando o cuidado de protegê-las da luminosidade e, a seguir, mantidas sob incubação em estufa $\left(37^{\circ} \mathrm{C}\right.$, em atmosfera úmida contendo $95 \%$ de ar e $5 \%$ de $\mathrm{CO}_{2}$ ) por período de 8 horas (Figura 4.6A).

Após este período, as placas eram levadas à capela de fluxo laminar e $500 \mu \mathrm{L}$ de solução solvente SDS eram aplicadas nos referidos poços. As placas retornavam novamente para a estufa por 12 horas (Figura 4.6B). 


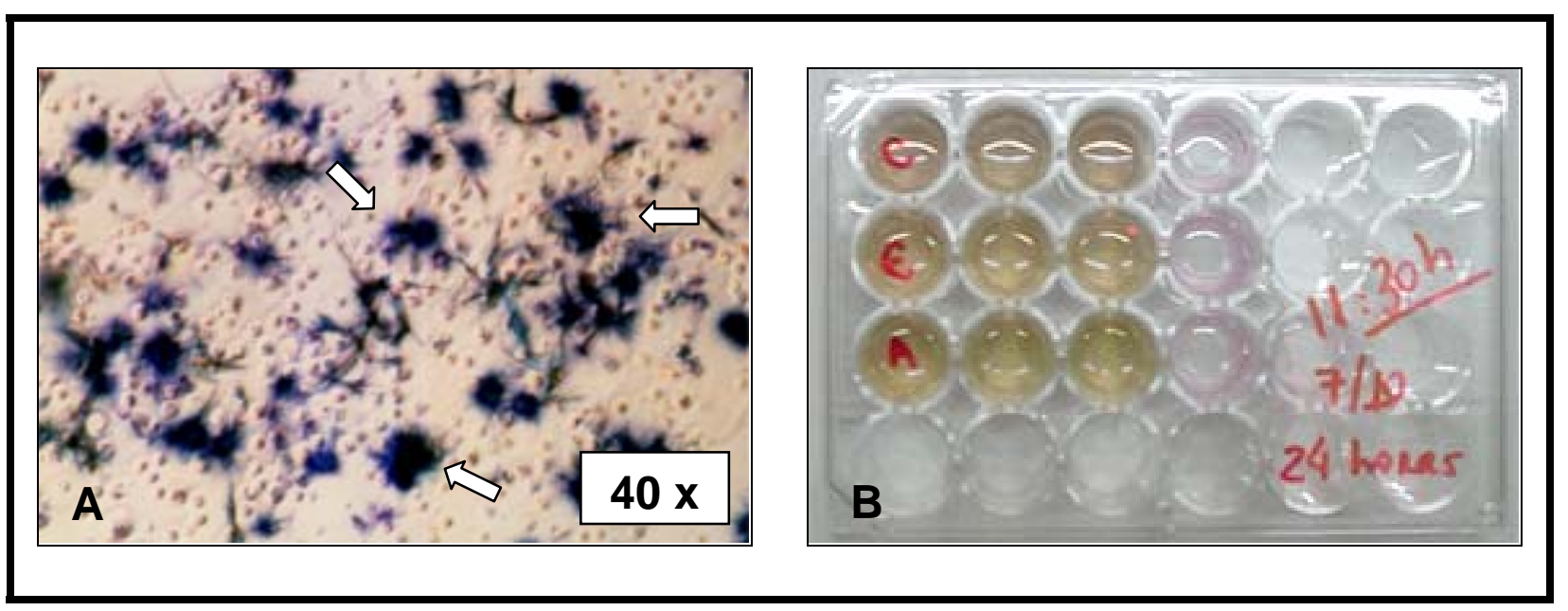

Figura 4.6A - Amostra experimental após o período de incubação com MTT (Setas - notar a formação dos cristais de formazina). Figura 4.6B - Placa de cultura dos grupos experimentais após aplicação de corante MTT e solução reveladora SDS

Concluído o período de 12 horas, procedeu-se a avaliação da viabilidade celular pelo cálculo da absorbância em leitora de ELISA a 550 nm (nanômetros) (Figura 4.7).

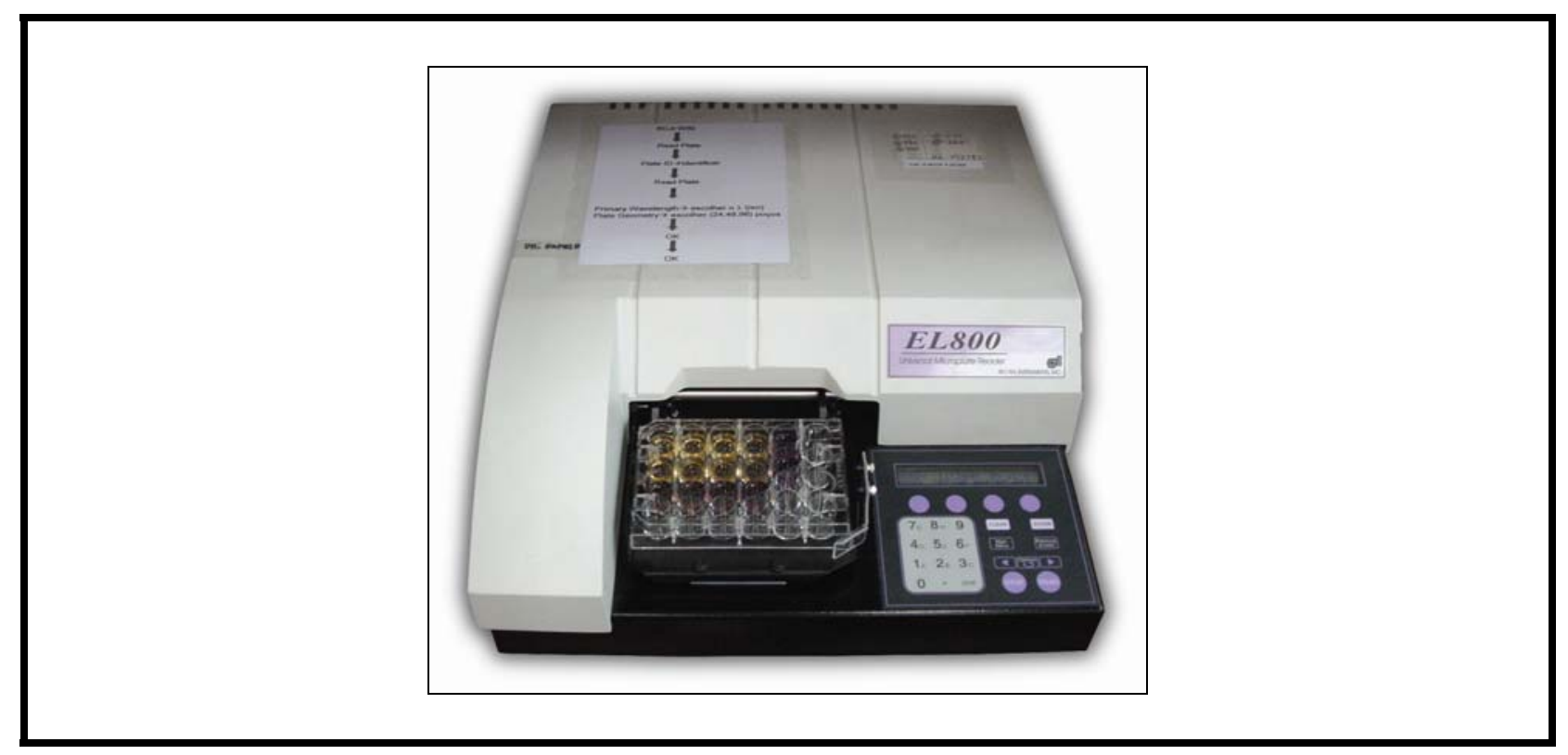

Figura 4.7 - Verificação da absorbância da placa de cultura, em leitora ELISA 550 nm 
Os valores expressos em $\mathrm{nm}$ foram analisados e comparados estatisticamente.

Ainda, estabelecendo-se uma relação entre os dados experimentais e os valores das diluições celulares que constituíram as amostras-padrão foram convertidos em número de células por milímetro, obtendo-se curvas de viabilidade celular e o número de células presentes nas amostras em função do tempo.

\subsubsection{Citotoxicidade celular de médio prazo}

As amostras celulares foram distribuídas numa concentração de $5 \times 10^{5}$ células por poço, em placas de cultura (24 poços), contendo os meios de cultivo celular determinados pelos diferentes grupos experimentais e testados após períodos de 1, 3, 5 e 7 dias.

Ao final dos referidos tempos de contato, a viabilidade dos macrófagos foi estabelecida como descrito anteriormente.

Os valores resultantes da absorbância foram analisados e comparados estatisticamente.

Concluído o ensaio de médio prazo (7 dias), curvas de concentração celular em função do tempo foram realizadas. 


\subsubsection{Determinação das curvas-padrão}

Para realização das curvas-padrão procedeu-se a coleta e processamento celular conforme descrito nos itens já mencionados.

Alíquotas de células foram distribuídas em placas de cultura (24 poços) em duplicatas e completadas com meio Mc Coy's 5A estéril obtendo um volume final de 1,0 mL, obedecendo uma diluição celular crescente (Figura 4.8A), da seguinte forma:

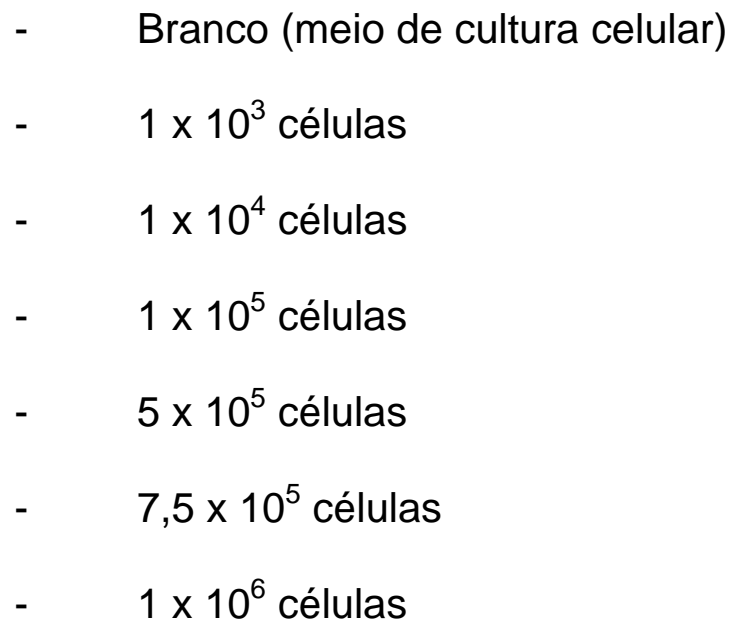

A viabilidade celular foi identificada pelo método MTT (Figura 4.8B) e os valores de absorbância determinados em leitora de ELISA a 550 nm.

No total foram realizados 3 grupos-padrão correspondentes aos tempos experimentais 0, 6, 12 horas; 1 e 3 dias; 5 e 7 dias.

Os valores de absorbância obtidos foram convertidos em valores de concentração de células por meio de equação logarítmica, determinando-se a reta média do padrão.

Os dados correspondentes aos ensaios de curto e médio prazo foram comparados aos valores do padrão, calculando-se assim a viabilidade e o número de células presentes de cada grupo avaliado em função do tempo. 


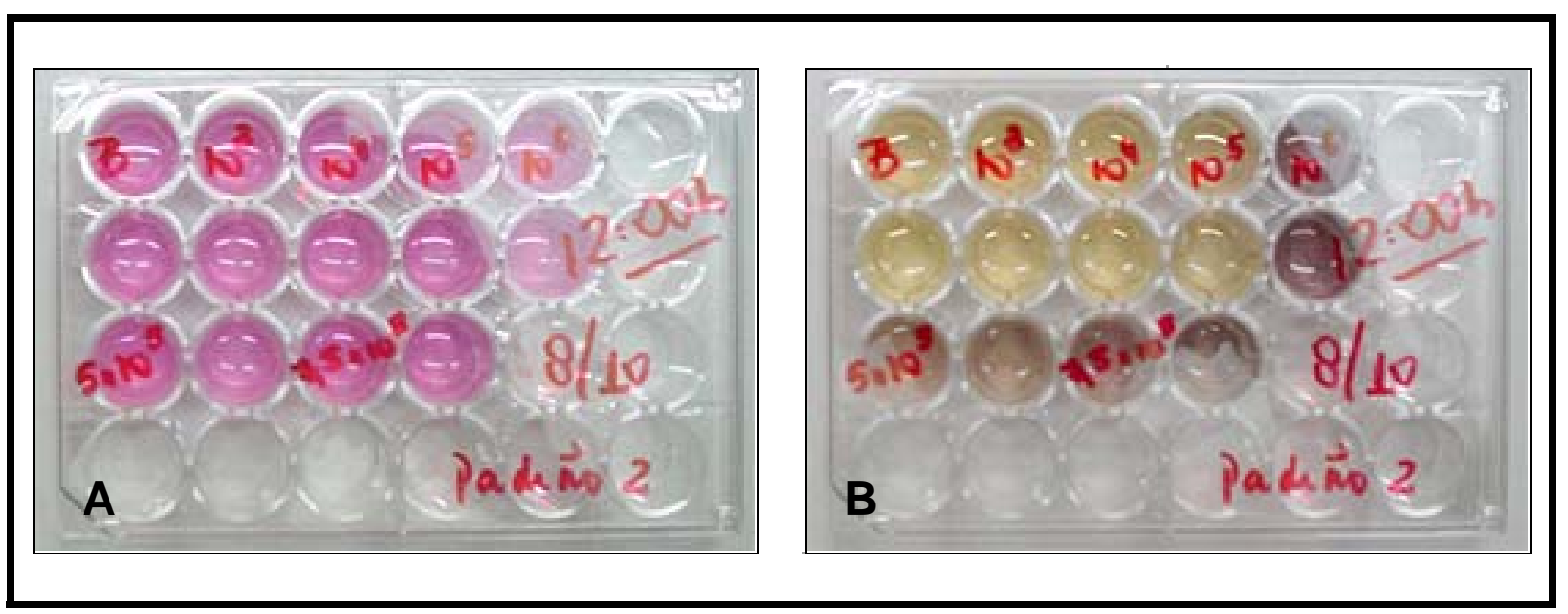

Figura 4.8A - Placa de cultura das amostras-padrão. Figura 4.8B - Placa de cultura do padrão após aplicação de corante MTT e solução reveladora SDS

\subsubsection{Análise estatística}

Todo o procedimento experimental foi repetido duas vezes. Os valores apresentados nos dois ensaios foram ordenados e tabulados, e assim, obtidas as médias e desvios-padrão em função dos grupos e tempos experimentais.

Os dados obtidos foram submetidos ao teste estatístico de análise de variância e, quando necessário, complementados pelo teste de Tukey para comparação entre as médias (programa estatístico Prisma 2003).

As diferenças estatísticas foram consideradas significantes ao nível de $5 \%$ ( $p<$ $0,05)$. 


\section{RESULTADOS}

No total foram realizados dois ensaios laboratoriais compreendendo amostras em triplicata para cada solução irrigadora e tempo observados (Apêndices A e B), perfazendo um total de seis dados amostrais para cada grupo (Anexos B1 e C1).

Os valores médios de absorbância (em nanômetros - nm) e desvios-padrão correspondentes aos grupos experimentais e seus respectivos tempos de observação estão expressos na Tabela 5.1.

Tabela 5.1 - Absorbância média (nm) e desvio-padrão dos dados amostrais

\begin{tabular}{l|cccccc}
\hline \multirow{2}{*}{} & \multicolumn{2}{|c}{ Controle } & \multicolumn{2}{c}{ EDTA } & \multicolumn{2}{c}{ Ácido cítrico } \\
& Média & Desvio Padrão & Média & Desvio Padrão & Média & Desvio Padrão \\
\hline 0 Horas & 0,391 & 0,021 & 0,315 & 0,037 & 0,296 & 0,027 \\
6 Horas & 0,337 & 0,016 & 0,261 & 0,019 & 0,250 & 0,027 \\
12 Horas & 0,347 & 0,116 & 0,230 & 0,014 & 0,248 & 0,023 \\
24 Horas & 0,344 & 0,016 & 0,204 & 0,007 & 0,244 & 0,046 \\
1 Dia & 0,344 & 0,016 & 0,204 & 0,0066 & 0,244 & 0,046 \\
3 Dias & 0,324 & 0,015 & 0,149 & 0,0193 & 0,236 & 0,031 \\
5 Dias & 0,292 & 0,032 & 0,141 & 0,0303 & 0,205 & 0,029 \\
7 Dias & 0,278 & 0,046 & 0,138 & 0,2520 & 0,191 & 0,017 \\
\hline
\end{tabular}


Para uma avaliação mais criteriosa, os resultados apresentados foram agrupados em: resposta celular de curto prazo ou imediata, resposta celular de médio prazo ou tardia e viabilidade celular em função da solução testada e do tempo.

O experimento de curto prazo corresponde aos períodos de 0, 6, 12 e 24 horas em que as células macrofágicas se mantiveram em contato com os meios de cultura celular condicionados com EDTA e ácido cítrico.

Os dados originais do experimento de curto prazo foram submetidos ao teste de aderência à curva normal, comprovando que a distribuição era normal, possibilitando a aplicação do teste de variância para detecção de diferenças estatísticas entre os itens avaliados (Anexos B).

A análise de variância, para 2 fatores de variação, mostrou diferenças significantes ao nível de $5 \%$ para as diferentes soluções avaliadas, sendo $\mathrm{F}_{\text {calculado }}=$ 46,07 contra $F_{\text {tabelado }}=3,15$ para 2 graus de liberdade. $O$ teste de Tukey revelou que o Grupo controle (0,355 nm) exibiu melhores resultados em comparação aos Grupos do $\operatorname{EDTA}(0,253 \mathrm{~nm})$ e do ácido cítrico $(0,260 \mathrm{~nm})$, independente do tempo observado. Confrontando-se o Grupo do EDTA e do ácido cítrico, não houve diferença estatística (Figura 5.1).

As diferenças entre as médias dos grupos experimentais estão representadas na Tabela 5.2. 


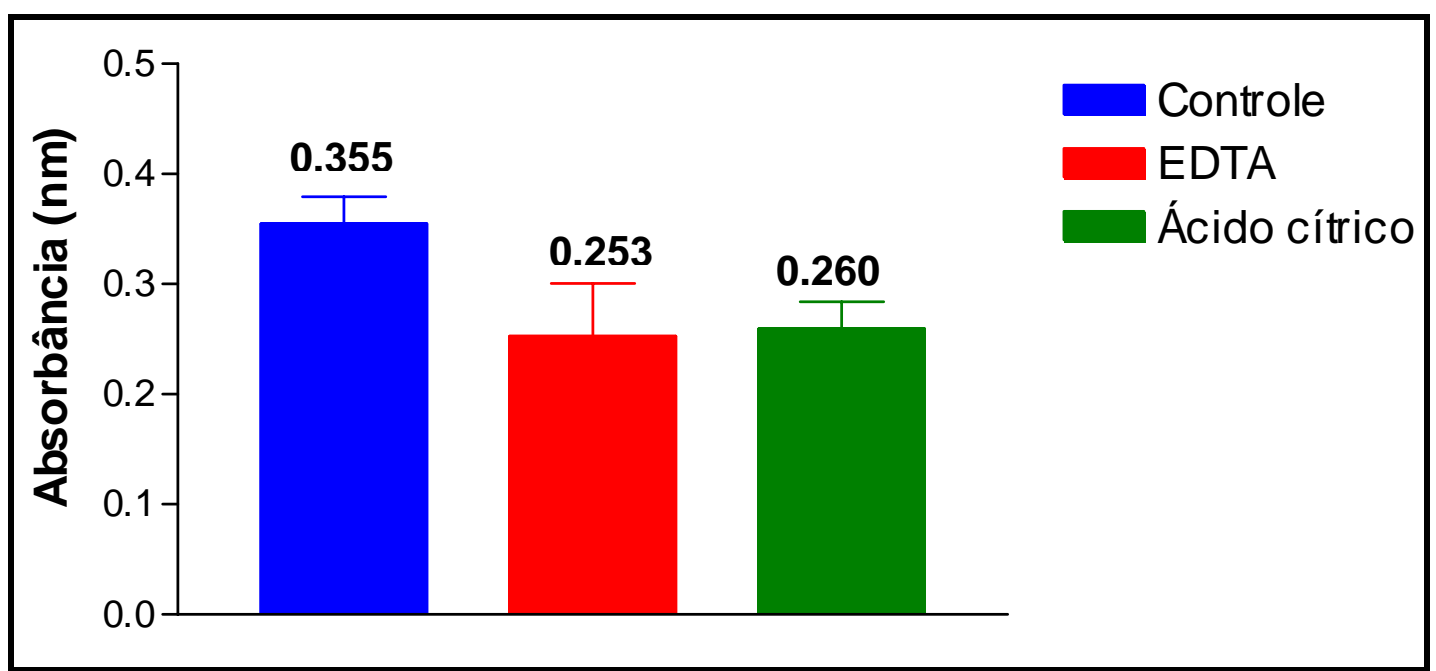

Figura 5.1 - Absorbância média (nm) dos grupos experimentais, independente do tempo, para o período de curto prazo

Tabela 5.2 - Diferença entre as médias de absorbância dos grupos avaliados, para o período de curto prazo $(p<0,05)$

\begin{tabular}{l|cc}
\hline & Diferença entre médias (nm) & $\mathbf{p}<\mathbf{0 , 0 5}$ \\
\hline Controle x EDTA & 0,102 & $\mathrm{~s}$ \\
Controle X Ácido cítrico & 0,095 & $\mathrm{~s}$ \\
EDTA x Ácido cítrico & 0,007 & $\mathrm{~ns}$ \\
\hline \multicolumn{2}{c|}{$\mathrm{s}=$ Significante } & $\mathrm{ns}=$ Não significante
\end{tabular}

A análise de variância dos diferentes tempos, para $F_{\text {calculado }}=10,27$ contra $F_{\text {tabelado }}=2,76$ e 3 graus de liberdade, indicou significância estatística. Pelo teste de Tukey, o período de 0 horas $(0,334 \mathrm{~nm})$ apresentou resultados estatisticamente melhores em comparação aos demais tempos avaliados. Para os períodos 6 horas $(0,269 \mathrm{~nm}), 12$ horas $(0,275 \mathrm{~nm})$ e 24 horas $(0,244 \mathrm{~nm})$ não foram notadas diferenças estatísticas significantes (Figura 5.2 e Tabela 5.3). 


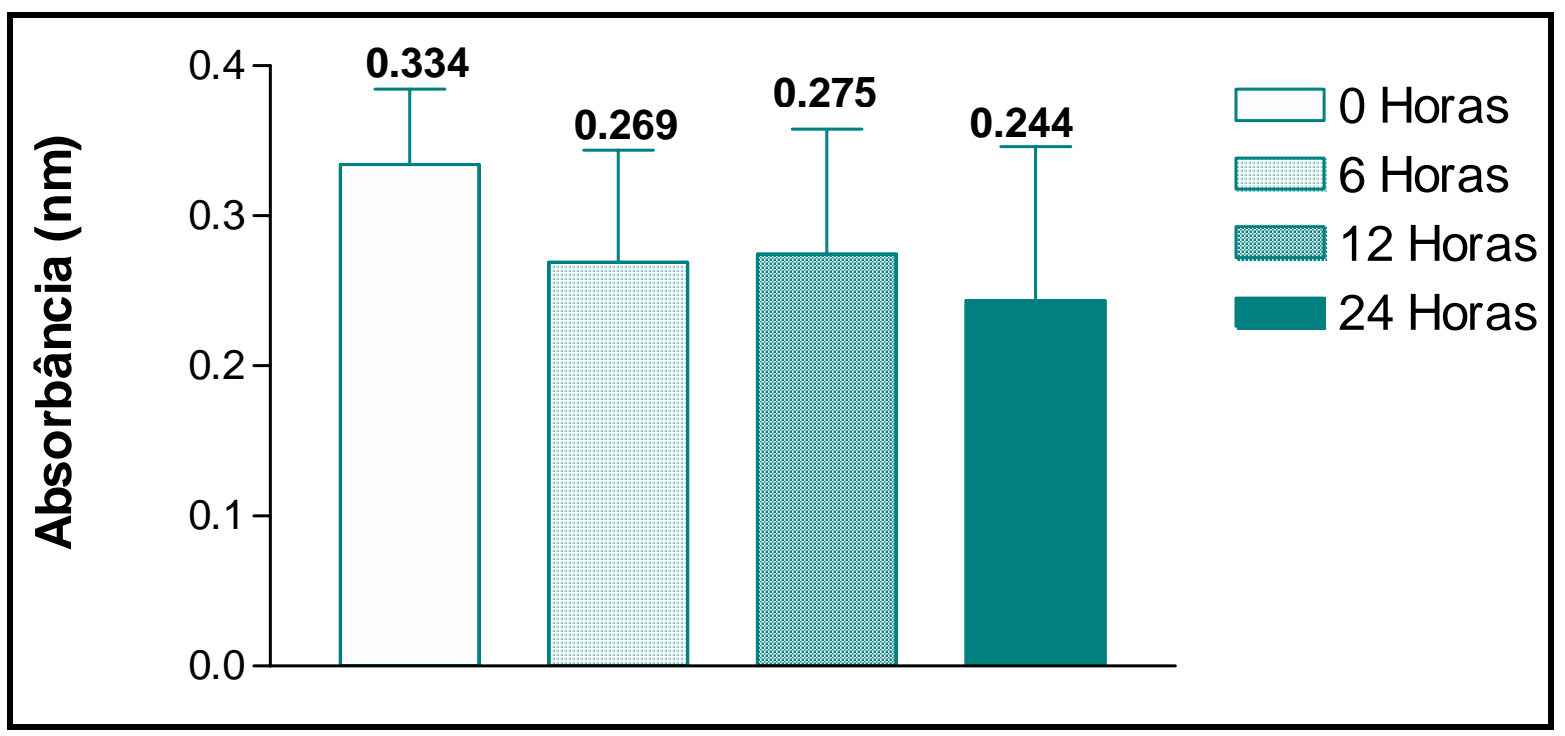

Figura 5.2 - Absorbância média $(\mathrm{nm})$ nos diferentes intervalos de tempo, independente da solução testada, para o período de curto prazo

Tabela 5.3 - Diferença entre as médias de absorbância dos tempos avaliados, para o período de curto prazo $(p<0,05)$

\begin{tabular}{l|cc}
\hline & Diferença entre médias $(\mathbf{n m})$ & $\mathbf{P}<\mathbf{0 , 0 5}$ \\
\hline 0 Horas x 6 Horas & 0,065 & $\mathrm{~s}$ \\
0 Horas x 12 Horas & 0,060 & $\mathrm{~s}$ \\
0 Horas x 24 Horas & 0,091 & $\mathrm{~s}$ \\
6 Horas x 12 Horas & 0,006 & $\mathrm{~ns}$ \\
6 Horas x 24 Horas & 0,026 & $\mathrm{~ns}$ \\
12 Horas x 24 Horas & 0,031 & $\mathrm{~ns}$ \\
\hline
\end{tabular}

$\mathrm{s}=$ Significante ns = Não significante

Os valores de absorbância do ensaio de curto prazo nos diferentes tempos de observação encontram-se na Tabela 5.4, bem como representados esquematicamente na Figura 5.3. 
Tabela 5.4 - Absorbância média (nm) e desvio-padrão, obtidos no período de curto prazo

\begin{tabular}{l|cccccc}
\hline & \multicolumn{2}{|c}{ Controle } & \multicolumn{2}{c}{ EDTA } & \multicolumn{2}{c}{ Ácido cítrico } \\
\hline & Média & Desvio Padrão & Média & Desvio Padrão & Média & Desvio Padrão \\
\hline 0 Horas & 0,391 & 0,021 & 0,315 & 0,037 & 0,296 & 0,027 \\
6 Horas & 0,337 & 0,016 & 0,261 & 0,019 & 0,250 & 0,027 \\
12 Horas & 0,347 & 0,116 & 0,230 & 0,014 & 0,248 & 0,023 \\
24 Horas & 0,344 & 0,016 & 0,204 & 0,007 & 0,244 & 0,046 \\
\hline
\end{tabular}

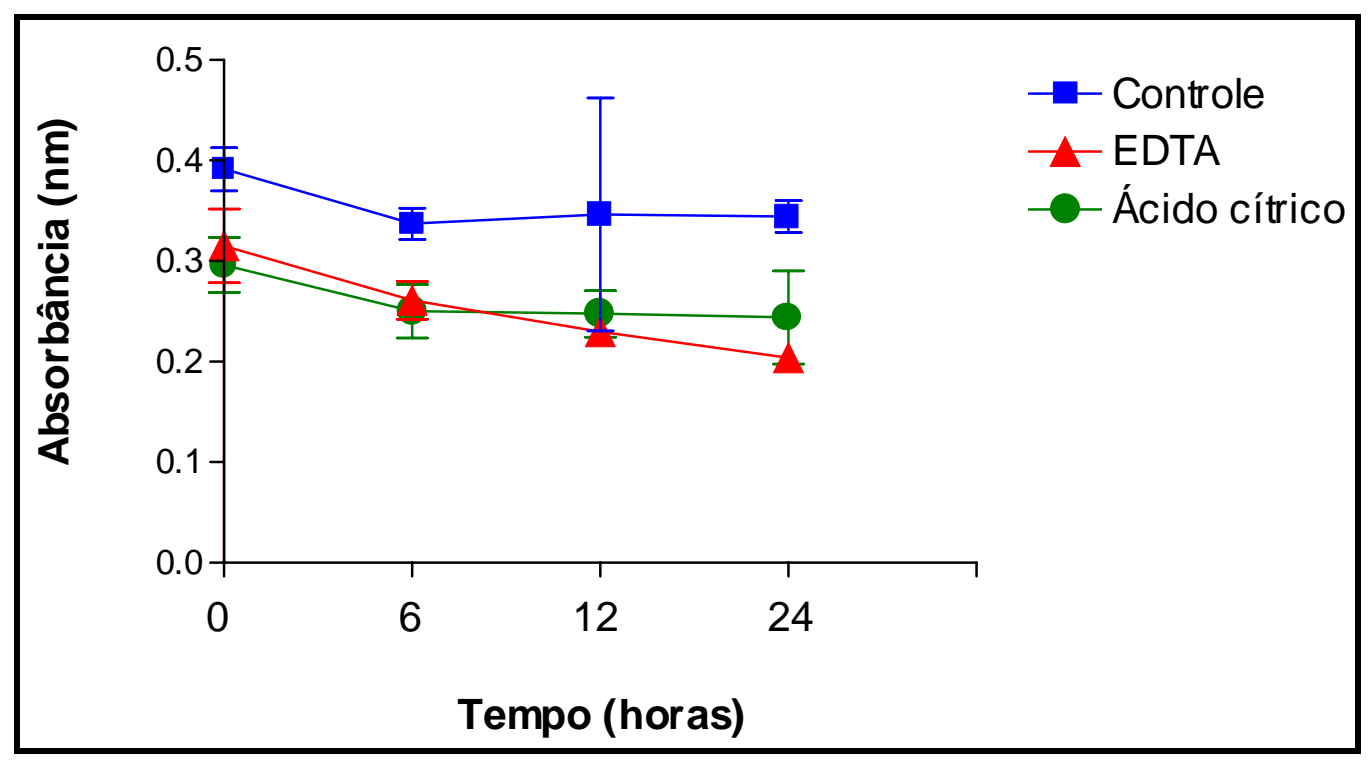

Figura 5.3 - Absorbância média (nm) dos grupos, em função do tempo, para o período de curto prazo

A interação solução $x$ tempo não revelou diferenças estatísticas $\left(F_{\text {calculado }}=\right.$ 1,041 contra $F_{\text {tabelado }}=2,25$, para 6 graus de liberdade).

Com relação à resposta celular de médio prazo, os resultados compõem os valores de absorbância, quando do contato dos macrófagos com os meios condicionados pelo EDTA e ácido cítrico nos períodos de 1, 3, 5 e 7 dias. 
Submetendo-se tais valores ao teste de aderência à curva normal, constatouse a normalidade da amostra, viabilizando a execução da análise de variância envolvendo 2 fatores de variação (Anexos C).

Os cálculos estatísticos apontaram diferenças significativas entre as soluções testadas para $p<0,05$, sendo $F_{\text {calculado }}=171,0$ contra $F_{\text {tabelado }}=3,15$ e 2 graus de liberdade. Pelo teste de Tukey, o Grupo controle $(0,310 \mathrm{~nm})$ indicou resultados significativamente melhores em relação ao Grupo do ácido cítrico $(0,219 \mathrm{~nm})$ e do EDTA $(0,158 \mathrm{~nm})$, ainda que estes dois grupos apresentaram diferenças significativas entre si (Figura 5.4 e Tabela 5.5).

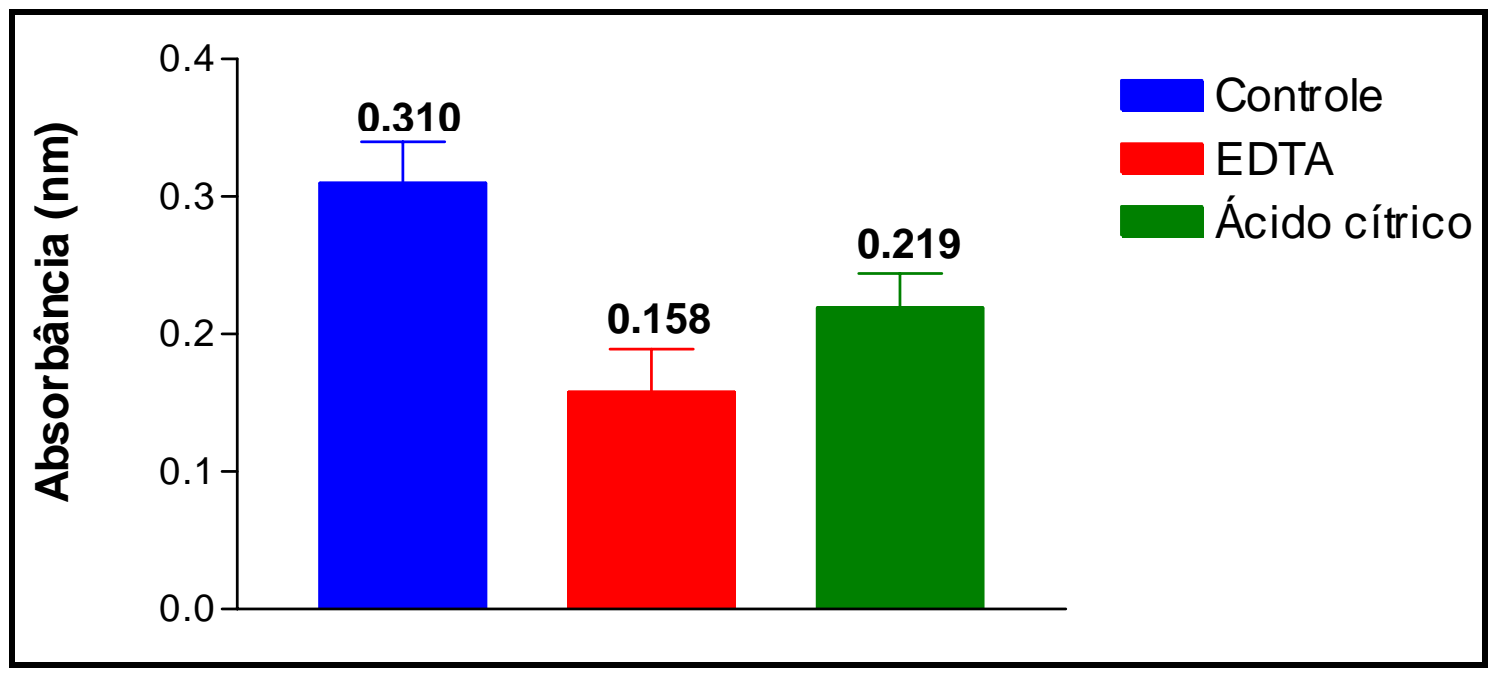

Figura 5.4 - Absorbância média $(\mathrm{nm})$ dos grupos experimentais, independente do tempo, para 0 período de médio prazo

Tabela 5.5 - Diferença entre as médias de absorbância dos grupos avaliados, para o período de médio prazo $(p<0,05)$

\begin{tabular}{l|cc}
\hline & Diferença entre médias (nm) & $\mathbf{P}<\mathbf{0 , 0 5}$ \\
\hline Controle x EDTA & 0,152 & $\mathrm{~s}$ \\
Controle X Ácido cítrico & 0,091 & $\mathrm{~s}$ \\
EDTA x Ácido cítrico & 0,061 & $\mathrm{~s}$ \\
\hline
\end{tabular}

$\mathrm{s}=$ Significante ns = Não significante 
No ensaio de médio prazo, as médias de absorbância dos grupos em função dos intervalos de tempo foram as seguintes: $0,264 \mathrm{~nm}, 0,237 \mathrm{~nm}, 0,212 \mathrm{~nm}, 0,203$ nm para os períodos de 1, 3, 5 e 7 dias, respectivamente.

Submetendo-se à avaliação estatística, os dados amostrais foram significantes a $5 \%\left(F_{\text {calculado }}=16,61\right.$ contra $F_{\text {tabelado }}=2,76$ para 3 graus de liberdade e Tukey crítico $=0,043$ ) para todos os intervalos de tempo avaliados, exceto entre o Grupo 5 dias $(0,212 \mathrm{~nm}) \times 7$ dias $(0,203 \mathrm{~nm})$ que não apresentaram diferenças estatísticas entre si.

O Grupo 1 dia mostrou resultados estatisticamente melhores em relação aos demais grupos, sendo: Grupo 1 dia $(0,264$ nm) x Grupo 3 dias; Grupo 1 dia (0,264 nm) $\times 5$ dias $(0,212 \mathrm{~nm}) ; 1$ dia $(0,264 \mathrm{~nm}) \times 7$ dias $(0,203 \mathrm{~nm})$. Também, o Grupo 3 dias $(0,237 \mathrm{~nm})$ apresentou resultados significativamente melhores quando comparados, tanto ao Grupos 5 dias (0,212 nm), quanto ao Grupo 7 dias (0,203 nm).

A Tabela 5.6 expressa as diferenças das médias entre os tempos avaliados.

Não houve significância estatística para a interação solução $x$ tempo $\left(F_{\text {calculado }}=0,868\right.$ contra $F_{\text {tabelado }}=2,25$ para 6 graus de liberdade $)$. 


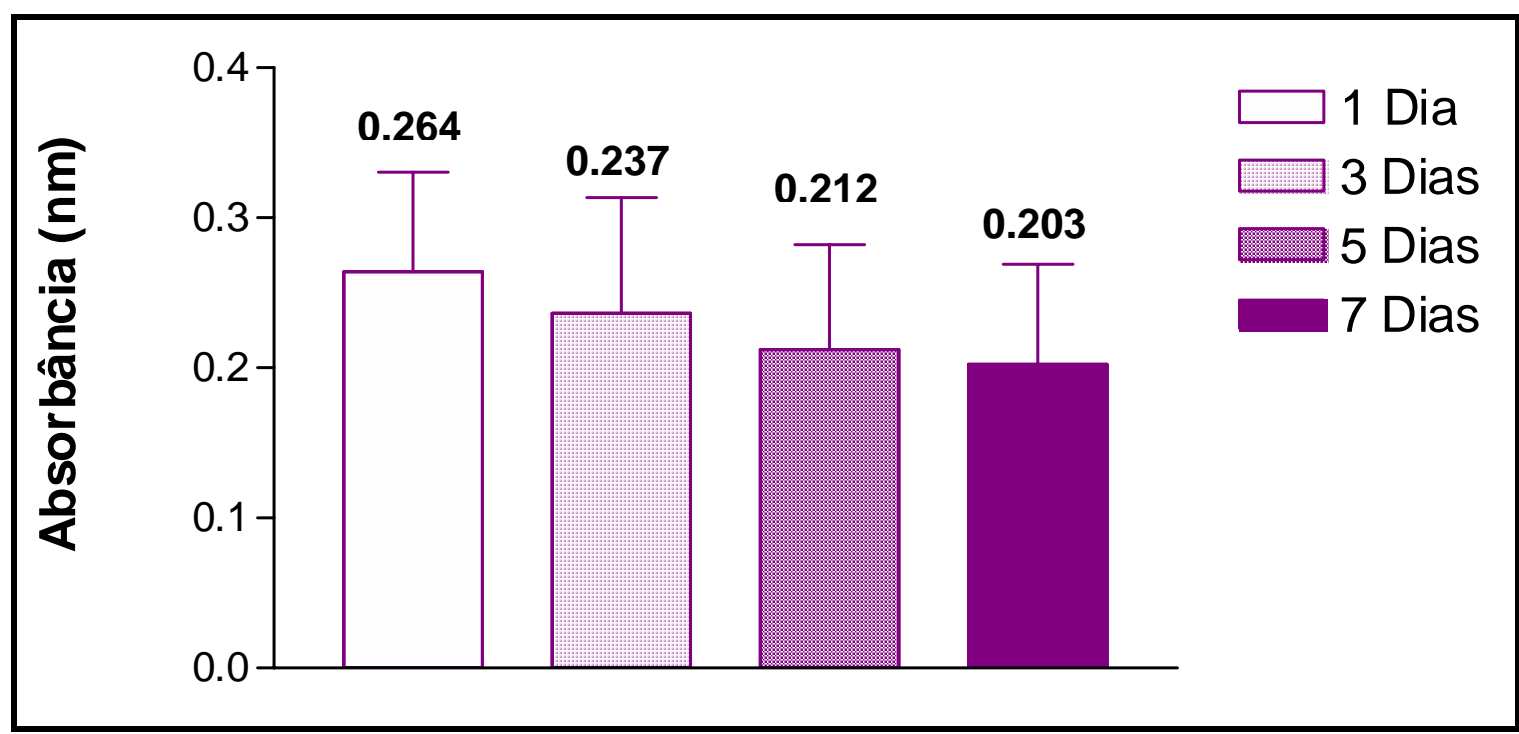

Figura 5.5 - Absorbância média $(\mathrm{nm})$ nos diferentes intervalos de tempo, independente da solução testada, para o período de médio prazo

Tabela 5.6 - Diferença entre as médias de absorbância dos tempos avaliados, para o estudo de médio prazo $(p<0,05)$

\begin{tabular}{l|cc}
\hline & Diferença entre médias (nm) & $\mathbf{P}<\mathbf{0 , 0 5}$ \\
\hline 1 Dia x 3 Dias & 0,028 & $\mathrm{~s}$ \\
1 Dia x 5 Dias & 0,052 & $\mathrm{~s}$ \\
1 Dia x 7 Dias & 0,062 & $\mathrm{~s}$ \\
3 Dias x 5 dias & 0,024 & $\mathrm{~s}$ \\
3 Dias x 7 dias & 0,034 & $\mathrm{~s}$ \\
5 Dias x 7 Dias & 0,010 & $\mathrm{~ns}$ \\
\hline \multicolumn{2}{c}{$\mathrm{s}=$ Significante } & $\mathrm{ns}=$ Não significante
\end{tabular}

A Tabela 5.7 e a Figura 5.6 representam a absorbância média das soluções irrigadoras observadas na cultura de macrófagos ( $n=5 \times 10^{5}$ células) durante os intervalos de observação, referentes ao estudo de médio prazo. 
Tabela 5.7 - Absorbância média (nm) e desvio-padrão, obtidos no período de médio prazo

\begin{tabular}{l|cccccc}
\hline & \multicolumn{2}{|c}{ Controle } & \multicolumn{2}{c}{ EDTA } & \multicolumn{2}{c}{ Ácido cítrico } \\
\hline & Média & Desvio Padrão & Média & Desvio Padrão & Média & Desvio Padrão \\
\hline 1 Dia & 0,344 & 0,016 & 0,204 & 0,0066 & 0,244 & 0,046 \\
3 Dias & 0,324 & 0,015 & 0,149 & 0,0193 & 0,236 & 0,031 \\
5 Dias & 0,292 & 0,032 & 0,141 & 0,0303 & 0,205 & 0,029 \\
7 Dias & 0,278 & 0,046 & 0,138 & 0,2520 & 0,191 & 0,017 \\
\hline
\end{tabular}

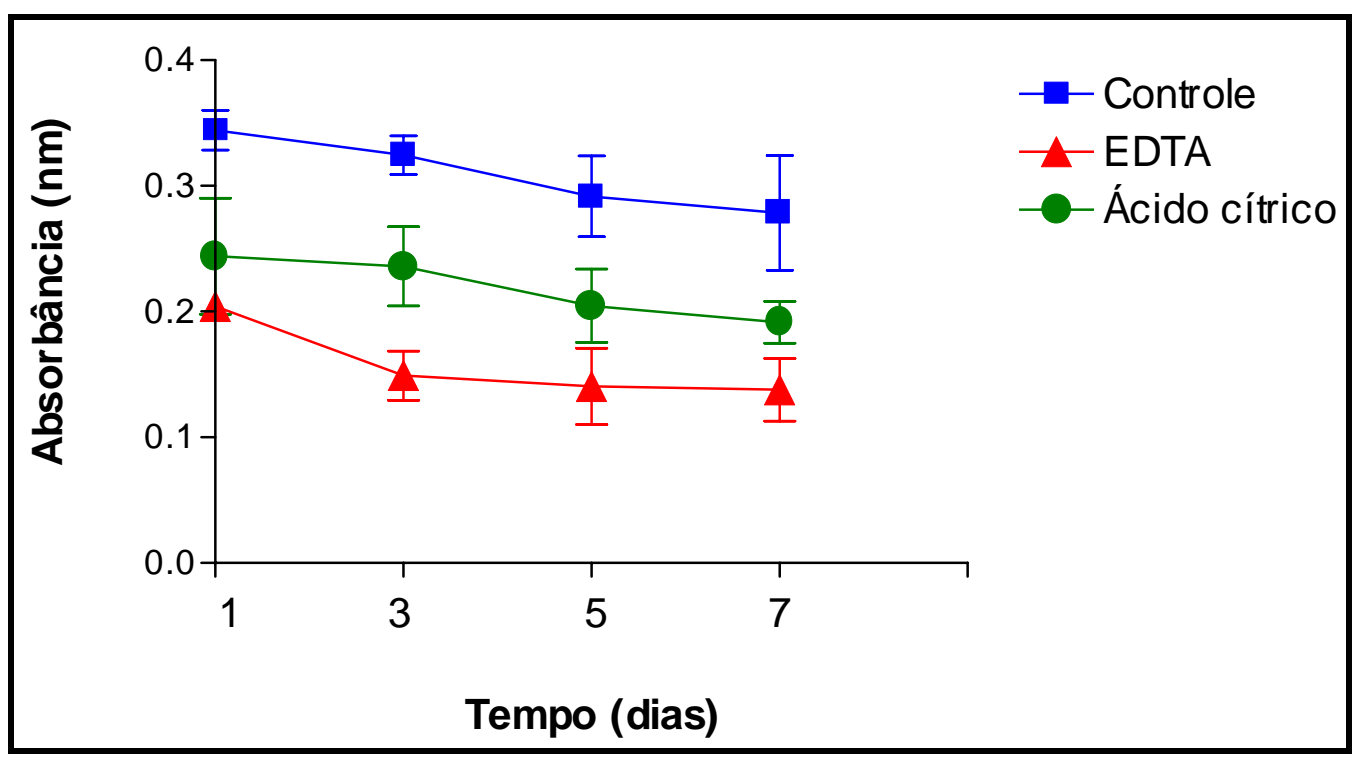

Figura 5.6 - Absorbância média $(\mathrm{nm})$ dos grupos, em função do tempo, para o período de médio prazo

A viabilidade celular, resultante da média dos 2 ensaios experimentais e confrontada à média do padrão (padrão do ensaio 1 e 2), apresenta-se na Tabela 5.8 e Figura 5.7. 
Tabela 5.8 - Absorbância média (nm) e concentração de macrófagos, de acordo com os grupos e tempos experimentais

\begin{tabular}{l|cccccc}
\hline \multirow{2}{*}{ Tempo } & \multicolumn{2}{|c}{ Controle } & \multicolumn{2}{c}{ EDTA } & \multicolumn{2}{c}{ Ácido cítrico } \\
& $\begin{array}{c}\text { Absorbância } \\
\text { média } \\
(\mathrm{nm})\end{array}$ & $\begin{array}{c}\text { Concentração } \\
\text { celular } \\
\left(\mathrm{n} .{ }^{\circ} \text { cél/ } \mathrm{mL}\right)\end{array}$ & $\begin{array}{c}\text { Absorbância } \\
\text { média } \\
(\mathrm{nm})\end{array}$ & $\begin{array}{c}\text { Concentração } \\
\text { celular } \\
\left(\mathrm{n}^{\circ}{ }^{\circ} \text { cél/ } \mathrm{mL}\right)\end{array}$ & $\begin{array}{c}\text { Absorbância } \\
\text { média } \\
(\mathrm{nm})\end{array}$ & $\begin{array}{c}\text { Concentração } \\
\text { celular } \\
\left(\mathrm{n}^{\circ}{ }^{\circ} \text { cél/ } \mathrm{mL}\right)\end{array}$ \\
\hline Inicial $(-1)$ & 0,391 & 679.050 & 0,391 & 679.050 & 0,391 & 679.050 \\
0 horas & 0,391 & 679.050 & 0,315 & 489.050 & 0,296 & 441.550 \\
6 horas & 0,337 & 544.050 & 0,261 & 354.050 & 0,250 & 326.550 \\
12 horas & 0,347 & 569.050 & 0,230 & 276.550 & 0,248 & 321.550 \\
1 dia & 0,344 & 556.250 & 0,204 & 206.250 & 0,244 & 306.250 \\
3 dias & 0,344 & 556.250 & 0,204 & 206.250 & 0,244 & 306.250 \\
5 dias & 0,324 & 506.250 & 0,149 & 68.750 & 0,236 & 286.250 \\
7 dias & 0,292 & 421.250 & 0,141 & 43.750 & 0,205 & 203.750 \\
\hline
\end{tabular}

Cada ensaio apresentou uma projeção da viabilidade celular em função do tempo de contato com os meios condicionados, partindo-se de uma concentração de $\mathrm{n}=5 \times 10^{5}$ macrófagos/ mL (Apêndices A e B).

Para tanto, diluições crescentes de macrófagos (em duplicata) foram realizadas paralelamente, definindo os grupos-padrão para os seguintes segmentos: 0, 6 e 12 horas - Padrão 1; 1 e 3 dias - Padrão 2; 5 e 7 dias - Padrão 3.

A partir do padrão, estabeleceu-se uma relação direta e proporcional entre a concentração de células viáveis e a absorbância, compondo uma curva de concentração num gráfico de coordenadas e abscissas. Traçando-se uma reta média desta curva, obtém-se uma equação logarítmica (Anexos D) e, por esta projetou-se os valores encontrados de absorbância dos diferentes grupos testados em número de células viáveis/ mL. 


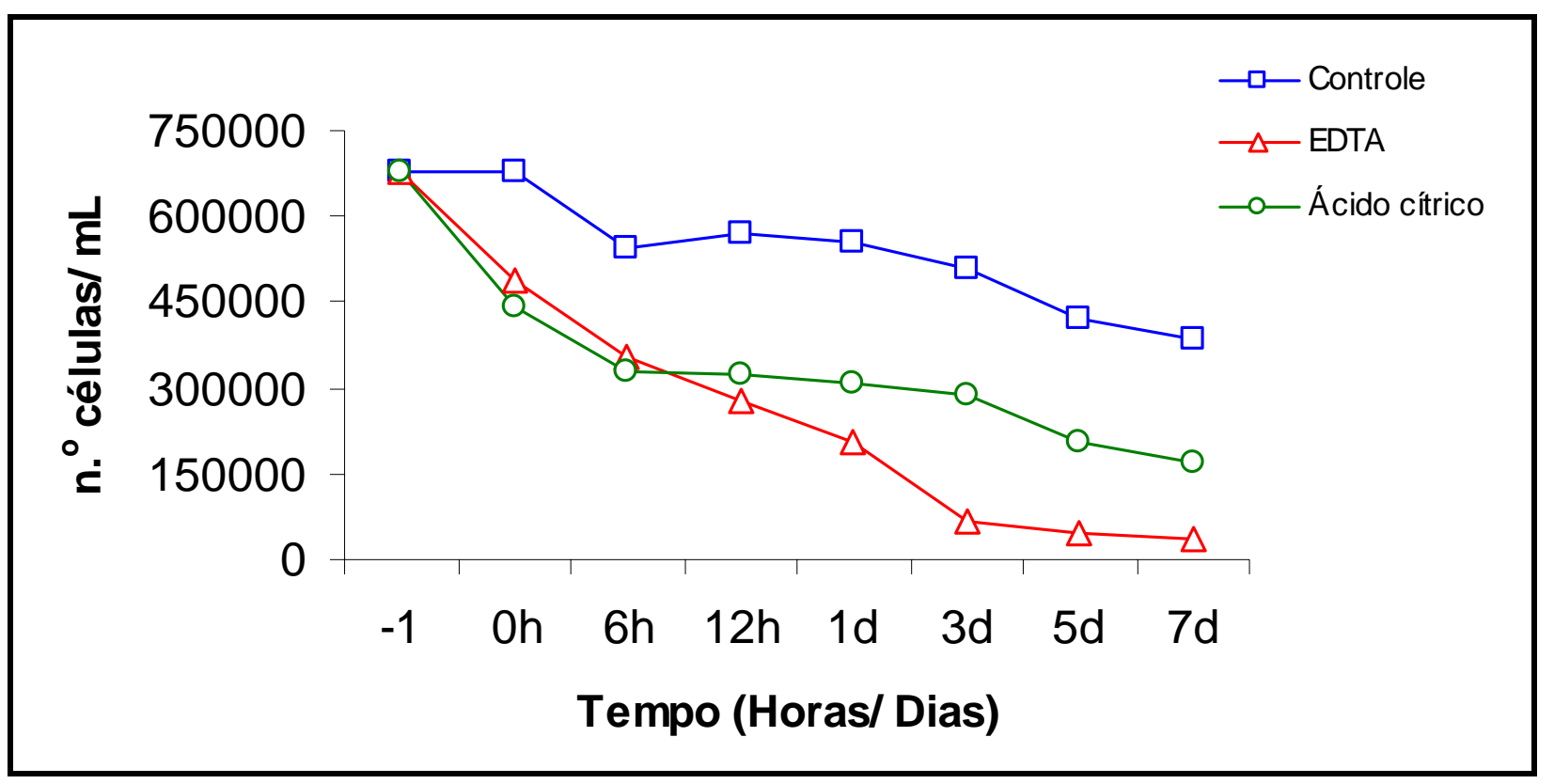

Figura 5.7 - Curva de viabilidade celular (concentração de macrófagos) em função da solução e tempo

Da mesma forma, as Tabelas 5.9 e 5.10 mostram a concentração de macrófagos dos grupos e tempos experimentais, respectivamente, obtidos no período de curto prazo bem como no médio prazo, mediante os valores de absorbância encontrados e anteriormente descritos.

Tabela 5.9 - Relação entre a absorbância e concentração de macrófagos dos grupos experimentais

\begin{tabular}{l|cccc}
\hline & \multicolumn{2}{|c}{ Curto prazo } & \multicolumn{2}{c}{ Médio prazo } \\
\hline & Absorbância (nm) & Concentração celular & Absorbância (nm) & Concentração celular \\
\hline Controle & 0,355 & 589.050 & 0,310 & 466.250 \\
EDTA & 0,253 & 334.050 & 0,158 & 86.250 \\
Ácido cítrico & 0,260 & 351.550 & 0,219 & 238.750 \\
\hline
\end{tabular}


Tabela 5.10 - Relação entre a absorbância e concentração de macrófagos dos tempos experimentais

\begin{tabular}{lccccc}
\hline \multicolumn{3}{c}{ Curto prazo } & \multicolumn{3}{c}{ Médio prazo } \\
\hline & $\begin{array}{c}\text { Absorbância } \\
(\mathrm{nm})\end{array}$ & $\begin{array}{c}\text { Concentração } \\
\text { celular }\end{array}$ & & $\begin{array}{c}\text { Absorbância } \\
(\mathrm{nm})\end{array}$ & $\begin{array}{c}\text { Concentração } \\
\text { celular }\end{array}$ \\
\hline $\mathbf{0}$ Horas & 0,334 & 536.550 & $\mathbf{1}$ Dia & 0,264 & 356.250 \\
$\mathbf{6}$ Horas & 0,269 & 374.050 & $\mathbf{3}$ Dias & 0,237 & 288.750 \\
$\mathbf{1 2}$ Horas & 0,275 & 389.050 & $\mathbf{5}$ Dias & 0,212 & 221.250 \\
24 Horas & 0,244 & 306.250 & 7 Dias & 0,203 & 198.750 \\
\hline
\end{tabular}




\section{DISCUSSÃO}

A terapia endodôntica baseia-se no diagnóstico e tratamento das patologias de origem pulpar e ou periapicais objetivando a cura, restabelecimento e integração do elemento dental aos demais componentes da cavidade oral.

Durante o preparo radicular, as substâncias químicas - em conjunto aos instrumentos endodônticos - contribuem efetivamente na limpeza das paredes dentinárias, quer na desintegração tecidual, quer na lise de microorganismos presentes no sistema de canais radiculares ou mesmo na remoção de magma dentinário.

Aliás, a presença de magma interfere negativamente na qualidade do tratamento endodôntico (CLARK-HOLKE et al., 2003; PÉCORA et al., 2001; TAKEDA et al., 1999), tanto que a partir dos estudos de Nygaard-Ostby (1957), o EDTA e suas associações têm sido amplamente utilizados como agente irrigante, culminando para a eliminação desta barreira mecânica (HÜLSMANN; HECKENDORFF; SCHÄFERS, 2002).

Goldberg e Abramovich (1977), Baumgartner e Mader (1987), Peters e Barbakow (2000) confirmam aumento do diâmetro dos túbulos e menor grau de sujidade dentinária quando do emprego do EDTA. E também, Beltz, Torabinejad e Pouresmail (2003) destacam melhor capacidade de solubilização de corpos de prova de dentina que as soluções de hipoclorito de sódio ou MTAD. 
Nesta ordem de idéias, o ácido cítrico também mostra-se eficaz na dissolução da camada inorgânica do magma dentinário, principalmente no segmento apical do canal (BAUMGARTNER et al., 1984; WAYMAN et al., 1979). Desmistificando que o aumento da concentração das soluções irrigantes potencializaria os efeitos desmineralizantes sob a dentina, Caba e Gavini (1999), Haznedaroglu (2003), Hennequin, Pajot e Avignant (1994), Malheiros e Gavini (1998) comprovam que o ácido cítrico a 15\%, tamponado em pH ácido, promove maior dissolução do magma e conseqüente aumento da permeabilidade dentinária, sem que haja a precipitação de cristais de citrato de cálcio.

No entanto, alguns autores são concordantes que tanto o EDTA quanto o ácido cítrico desempenham, igualmente, elevada limpeza e maior permeabilidade do canal radicular (GARBEROGLIO; BECCE, 1994; GAVINI, 1994; YAMAGUCHI et al., 1996; SCELZA; ANTONIAZZI; SCELZA, 2000; SCELZA; TEIXEIRA; SCELZA, 2003).

Ainda, com relação a sanificação do canal radicular, atribui-se ao EDTA e ao ácido cítrico propriedades bactericidas contra algumas cepas de microorganismos (BERUTTI; MARINI; ANGERETTI, 1997; BYSTRÖM; SUNDQVIST, 1985; NIKOLAUS; WAYMAN; ENCIMAS, 1988; SMITH; WAYMAN, 1986; YAMAGUCHI et al., 1996; YOSHIDA et al., 1995). Siqueira et al. (1998) enfatizam que o EDTA bem como o ácido cítrico inibiu o crescimento de bactérias anaeróbias facultativas, porém em menores proporções que o hipoclorito de sódio.

Já Heling e Chandler (1998), Orstavik e Haapasalo (1990) são de opinião que o EDTA, utilizado isoladamente, não apresenta atividade antimicrobiana.

Cabe-nos enfatizar que, independente das propriedades físico-químicas, as soluções irrigadoras devem atuar nos limites do canal radicular, pois o 
extravasamento além do forame apical pode alterar sensivelmente o metabolismo periapical (MEHRA; CLANCY; WU, 2000).

De fato, a região periapical é composta por uma variedade de tecidos, vasos sanguíneos, fibras nervosas e uma complexidade de componentes celulares desde fibroblastos, osteoblastos, osteoclastos até as inúmeras células inflamatórias: neutrófilos, monócitos, macrófagos, linfócitos, entre outros.

Quanto menor a agressão gerada aos tecidos periapicais, mais rápida e eficaz se instalará a reparação (HAUMAN; LOVE, 2003). É justamente nesta afirmativa que reside a utilização de técnicas de preparo menos invasivas e produtos biologicamente compatíveis, como ressalta o European Comitee for Standardization - EN 1441 (1996), ISO 7405 e ISO 106 (1997).

Indubitavelmente, durante a modelagem do canal radicular ocorre a formação resíduos dentinários e a extrusão de debris para a região apical foge ao controle do endodontista. Lara et al. (2003) ressaltam que, na presença de componentes protéicos da dentina, as células inflamatórias são mobilizadas e ainda elevam a concentração de mediadores químicos. Deste modo, a adoção de técnicas de preparo que minimizem a extrusão apical é fundamental (AL-OMARI; DUMMER, 1995; BERGMANS et al., 2001; DEONÍZIO, 2001; DEONÍZIO; GAVINI; PANTAROLO, 2002; FERRAZ et al., 2001).

Por outro lado, desde os estudos de Coolidge (1930), Nery, Souza e Holland (1974), Torneck (1961) procurava-se avaliar as reações biológicas quando do emprego de diversos materiais endodônticos, sejam estes medicamentos, soluções irrigadoras ou mesmo cimentos obturadores, por meio de análise histológica ou, mais recentemente por técnicas laboratoriais como o cultivo celular (HAGLUND et al., 2003; KOULAOUZIDOU et al., 1999; MENDES et al., 2003; 
SADEGHEIN; BOLHARI; SARAFNEJAD, 2001; SEGURA et al., 1997; ZHANG; TORABINEJAD; LI, 2003).

A agressão gerada nos tecidos periapicais induz uma série de eventos inflamatórios agudos ou inespecíficos, que são comandados principalmente pelos macrófagos. Estas células são responsáveis pelo reconhecimento e fagocitose de agentes irritantes, ativação de linfócitos, apresentação antígeno-anticorpo, liberação de mediadores químicos e citocinas (SJÖGREN; SUNDQVIST; LERNER, 1998), além de atuarem no mecanismo de regulação e remodelação tecidual (METZGER, 2000).

Conforme descritos por Mendes et al. (2003) e Syrjänen, Nilner e HenstenPettersen (1986), a presença de produtos odontológicos pode inibir o mecanismo de fagocitose dos macrófagos, bem como a síntese de óxido nítrico (NO).

À sua vez, Haglund et al. (2003) e Kostoryz et al. (2003) salientam a secreção de citocinas, IL-1ß e IL-6, em virtude da atividade citotóxica de cimentos retro-obturadores e adesivos dentinários, respectivamente, sob cultura de macrófagos.

Com o avanço tecnológico no campo da imuno-histoquímica, as pesquisas têm evidenciado, cada vez mais, a participação efetiva de macrófagos em sítios de lesões periapicais ativas bem como em reparação (AKAMINE et al., 1994; KAWASHIMA et al., 1996; KOPP; SCHWARTING, 1989; METZGER; BERG; DOTAN, 1997; PIATELLI et al., 1991).

O conhecimento dos fenômenos inflamatórios envolvidos, mais especificamente o comportamento das células macrofágicas diante das soluções de EDTA a $17 \%$ e ácido cítrico a $15 \%$ empregadas na irrigação final de canais radiculares, motivou a elaboração e execução desta pesquisa in vitro. 
Dentre os estudos de biocompatibilidade podemos agrupá-los em estudos in vitro exemplificados principalmente pela cultura de células, testes secundários em animais como a implantação de substâncias (BHAMBHANI; BOLANOS, 1993; YESILOY et al., 1995) e sensibilização de mucosa ou conjuntivo (ATTALLA; CALVERT, 1969; BOMBANA et al., 1974; NUNES, 2002) e finalmente testes clínicos (HARRISON; SVEC e BAUMGARTNER, 1978; MESTRENER; HOLLAND; DEZAN, 2003; SCARANO et al., 2003).

Atualmente, no que diz respeito à ética em pesquisa, existe uma tendência em aplicarmos nossos conhecimentos primeiramente no âmbito laboratorial e, uma vez colhidos os resultados pertinentes, extrapolarmos para os estudos in vivo.

Paralelamente, graças aos estudos laboratoriais é possível avaliar isoladamente o modo de atuação ou efeito de um componente químico específico presente em um material (LEISKAR; HELGELAND, 1981).

Somados a estas afirmativas, a cultura de células apresenta simplicidade técnica, sensibilidade metodológica e baixo custo quando comparados aos estudos in vivo (HYAKUNA et al., 1989; SCHMALZ, 1994).

Como advogam Browne e Tyas (1979) e Schmalz (1994), a metodologia de cultura celular representa uma valiosa ferramenta para a compreensão da atividade das células frente aos materiais odontológicos testados, ainda que a padronização, reprodução e avaliação dos resultados devam ser criteriosamente definidas.

Para tanto, as soluções de EDTA e ácido cítrico foram adicionadas ao meio de cultura celular exatamente na forma com que são empregadas na clínica endodôntica. No entanto, utilizamos os meios de cultura condicionados com diluições de $0,5 \%$ dos irrigantes, acorde os resultados apontados por Malheiros (2000) e Masillamoni, Kettering e Torabinejad (1981). 
Ao nosso entender, para avaliação da capacidade citotóxica dos produtos odontológicos, as técnicas de cultivo celular permitem uma situação experimental mais facilmente controlada em comparação aos estudos in vivo e de grande representatividade estatística.

No presente estudo, optamos por trabalhar com linhagem primária de macrófagos obtidos da cavidade peritoneal de camundongos, uma vez que apresentam potencial metabólico específico parecido com as células-alvo presentes nos tecidos periapicais, além de fornecer concentrações elevadas de células (HANDEL-FERNANDEZ; LOPES, 2000).

Em concordância com Murphy e Newsholme (1999) e contrários às observações de Santos, Jaeger e Guedes-Pinto (2000) verificamos (em estudo piloto prévio) a inviabilidade no estabelecimento de cultura de macrófagos originados de linhagem permanente, pois em razão de sua alta diferenciação celular, estas células não se multiplicam facilmente em cultura.

Adversamente, Schmalz e Sharaf (1988) são partidários de que a linhagem celular permanente tende a ser mais sensível que a linhagem de células primárias. Porém, compartilhamos a mesma idéia de Santos et al. (1996) que, embora tenham trabalhado com fibroblastos, não demonstraram diferenças no comportamento destas células em decorrência de sua origem primária ou permanente.

Para minimizar ou descartar quaisquer variáveis que pudessem interferir nos resultados deste experimento, algumas precauções foram tomadas:

- As amostras celulares coletadas eram provenientes de camundongos da espécie Swiss, cedidos pelo Biotério das Químicas da Universidade de São Paulo. A concentração de macrófagos foi estabelecida mediante identificação histológica e contagem de células do citocentrifugado, obtendo-se em média 95\% de macrófagos. 
- A utilização de macrófagos peritoneais deve-se ao fato de que o sistema imunológico deste modelo animal guarda semelhança com o sistema imune humano.

- Utilização de animais machos e na idade adulta (8 a 12 semanas de vida), pois o comportamento hormonal e o metabolismo das células são muito próximos.

- Previamente à coleta, os animais não foram inoculados com soluções a base de tioglicolato ou caseína. Conforme Handel-Fernandes e Lopes (2000) tais agentes mobilizam quantidades elevadas de células, no entanto, a pré-ativação de macrófagos residentes poderia mascarar os efeitos decorrentes da ação das soluções irrigantes testadas.

- Os procedimentos laboratoriais desde obtenção, plaqueamento até inclusão de corante foram realizados em ambiente asséptico (capela de fluxo laminar), seguindo o protocolo elaborado pelo laboratório de Hematologia Clínica da Faculdade de Ciências Farmacêuticas da Universidade de São Paulo.

- Os ensaios de citotoxidade para os períodos de curto e médio prazo foram realizados com a mesma população celular.

- Para não tornar a pesquisa tendenciosa, houve duplicação de todo o experimento, sendo os dados dos 2 procedimentos experimentais representados nos Apêndices A e B.

Ao contrário de Fleit et al. (1984) que preconizam o uso de placas de cultura não aderentes, concentrações de macrófagos correspondentes a $5 \times 10^{5}$ células $/ \mathrm{mL}$ foram distribuídas em placas de poliestireno aderentes, justamente por serem consideradas mais apropriadas para o cultivo deste tipo celular, totalizando amostras em triplicata dos grupos experimentais,

Os efeitos de toxicidade do EDTA e ácido cítrico sob a cultura de macrófagos peritoneais foram mensurados mediante o grau de viabilidade celular pelo método 
MTT. Os trabalhos de Chan et al. (1999), Kostoryz et al. (2003), Osorio et al. (1998), Serper et al. (2001), Zhang, Torabinejad e Li (2003) nos asseguraram a eficiência desta metodologia de avaliação.

O corante MTT, inicialmente solúvel em água e de coloração amarela fluorescente, é incorporado por células viáveis no interior de sítios enzimáticos mitocondriais é metabolizado, adquirindo a forma de cristais de formazina composto insolúvel e de coloração azul escura (COLLIER; PRITSOS, 2003). Estes cristais são então solubilizados pelo detergente SDS, permitindo o cálculo da absorbância através de leitora ELISA num comprimento de onda de $550 \mathrm{~nm}$, sabendo-se que a absorbância é diretamente proporcional à concentração celular.

Comparando-se os dados dos grupos experimentais aos das amostraspadrão, que foram obtidas a partir de diluições celulares pré-determinadas, pudemos conhecer não só os valores de absorbância, mas também projetarmos curvas de viabilidade celular em função do tempo.

Jackson et al. (1994) relatam que a manipulação da monocamada de macrófagos para a contagem celular, seja esta realizada por raspagem ou tratamento químico, pode acarretar em danos às estruturas de adesão e depleção do metabolismo das células macrofágicas.

No entanto, a avaliação da toxicidade celular baseada na aplicação do MTT e posterior leitura da absorbância nos assegurou o menor grau de interferência externa à cultura de macrófagos e, conseqüentemente, resultados mais confiáveis.

Durante a execução do experimento piloto verificamos que, para obtermos uma reta média representativa do padrão (absorbância x concentração de células), as diluições celulares deveriam obedecer a seguinte ordem crescente: branco 
(somente meio de cultura), $1 \times 10^{3}, 1 \times 10^{4}, 1 \times 10^{5}, 5 \times 10^{5}, 7,5 \times 10^{5}$ e $1 \times 10^{6}$ células.

Com o intuito de minimizar possíveis erros de calibração, pipetagem, aliquotagem, entre outros, utilizamos os valores de uma determinada curva-padrão como parâmetros para cada intervalo de tempo proposto neste estudo, sendo estas realizadas concomitantemente às amostras experimentais. Assim, o experimento contou com 3 grupos-padrão: Padrão 1- tempo de 0, 6, 12 horas; Padrão 2- 24 horas, 1 dia e 3 dias; Padrão 3- 5 e 7 dias.

Como Mossman (1983), constatamos que a avaliação da toxicidade pelo corante MTT consiste em um método rápido, reproduzível, cuja interpretação não apresenta subjetividade como o método de contagem celular pela exclusão do azul de Trypan (KOULAOUZIDOU et al., 1999; MALHEIROS, 2000; SCELZA et al., 2001; SCHMALZ, 1994) ou verificação do halo de inibição (LEISKAR; HELGELAND, 1981).

Os dados obtidos foram avaliados em 2 momentos: ensaios de curto prazo (compreendendo os tempos de 0, 6, 12 e 24 horas), sugerindo o momento inicial de contato das soluções irrigantes quando, por meio de extrusão apical, atingiriam os tecidos periapicais e ensaio de médio prazo (avaliação aos 1, 3, 5 e 7 dias), em que procuramos avaliar o efeito residual, bem como a interferência destes irrigantes no crescimento dos macrófagos (FRESHNEY, 1990).

Conjugando as mesmas idéias de Kawahara, Yamagami e Nakamura (1968), os resultados apresentados neste estudo in vitro exibem a resposta biológica de um determinado componente celular inflamatório quando em contato com o EDTA ou ácido cítrico e, por este motivo os efeitos citotóxicos observados devem ser interpretados com parcimônia no âmbito dos tecidos periapicais. 
A distribuição dos dados amostrais foi considerada normal, tornado possível a comparação estatística das médias entre os grupos pela aplicação da análise de variância (ANOVA), considerando níveis de significância de $5 \%(p<0,05)$. Para a comparação entre as médias obtidas, realizamos o teste de Tukey (programa estatístico Prisma 2003).

Os resultados mostraram que no período de curto prazo, o EDTA e ácido cítrico exibiram padrão citotóxico superior ao grupo controle, justificados pela diminuição da população de macrófagos de aproximadamente $5,8 \times 10^{5}$ para $3,5 \times$ $10^{5}$ células $/ \mathrm{mL}$ em ambos os grupos experimentais (Tabela 5.9). Provavelmente, os agentes irrigantes exercem ação direta à cultura de macrófagos, alterando a superfície da membrana celular e, assim, aceleram o processo de apoptose. Por se tratar de soluções ácidas, o EDTA e ácido cítrico devem atuar indiretamente na disponibilidade de nutrientes do meio de cultura, pela diminuição do $\mathrm{pH}$ e, por fim, acentuam a redução do metabolismo das células (SPANGBERG, 1969). Um outro indício que comprova tal hipótese é que o grupo controle manteve a concentração de células praticamente inalterada até o período de 24 horas, enquanto o grupo do EDTA e do ácido cítrico já apresentavam marcante redução da população celular (metade da concentração inicial) no período de 6 horas (Tabela 5.8).

Segundo Segura et al. (1996, 1997), o EDTA inibe a ligação de peptídeos intestinais vasoativos - responsáveis pela modulação das respostas imunológicas da região periapical - e reduz a capacidade de aderência de macrófagos, de maneira concentração e tempo-dependente, prejudicando a reparação tecidual.

Mais recentemente, os mesmos autores (SEGURA-EGEA et al., 2003) comprovaram o efeito inibitório dos irrigantes EDTA e EGTA na capacidade de aderência de macrófagos após 5, 15 e 30 minutos, sugerindo que o extravasamento 
dessas soluções para a região apical poderiam ocasionar descalcificação da matriz óssea periapical como resultado da ação quelante, além de alterar as respostas inflamatórias e imunes periapicais, pois a fagocitose e apresentação antígenoanticorpo são funções totalmente dependentes da capacidade de aderência das células macrofágicas.

Segundo Çalt e Serper (2002), Serper e Çalt (2002), a atuação do EDTA sob a dentina radicular é quase imediata. Em poucos minutos de aplicação, a reação química com os cristais de hidroxiapatita é desencadeada, resultando em quelação dos componentes dentinários. Por outro lado, estes autores juntamente com Goldberg e Spielberg (1982) ressaltam que a ação contínua do EDTA sob a dentina resulta em erosão excessiva de túbulos dentinários e até mesmo exposição de matriz colágena.

Baseados nos achados de Chan et al. (1999), as soluções de ácido cítrico exercem atividade inibitória das células pulpares humanas em cultura proporcional à concentração e tempo utilizados, considerando que a diminuição do $\mathrm{pH}$ do meio de cultivo celular tenha sido o fator desencadeador dos efeitos tóxicos.

Gessani et al. (2000), também concordam que o baixo pH do meio de cultura influencia diretamente na diminuição da capacidade de aderência dos macrófagos.

Para Malheiros (2000), o EDTA mostrou acentuada citotoxicidade à cultura de fibroblastos $\mathrm{NHI}$ 3T3, ao passo que o ácido cítrico a $10 \%$ e $15 \%$ revelou compatibilidade estatisticamente superior. Da mesma forma, Scelza et al. (2001) apontaram comportamento semelhante ao de Malheiros (2000) com as soluções de EDTA-T e ácido cítrico a 10\%. A discordância dos resultados apresentados nesta pesquisa, talvez possa ser explicada pela elevada especificidade dos macrófagos em relação aos fibroblastos, o que tornaria a célula macrofágica mais reativa. 
Para Engström e Spangberg (1967) o EDTA apresenta-se menos citotóxico que o fenol e ácido sulfúrico. Entretanto, os efeitos deletérios destes produtos contra-indicam a sua utilização clínica e, portanto, ao nosso entender não servem como parâmetros de avaliação citotóxica.

Em relação aos tempos experimentais, observamos uma diminuição significativa do número de macrófagos para o Grupo 0 horas contra os demais grupos (6, 12 e 24 horas), demonstrando uma queda da viabilidade celular, em média de $5,4 \times 10^{5}$ células $/ \mathrm{mL}$ para $3,2 \times 10^{5}$ células $/ \mathrm{mL}$. (Tabela 5.10 ).

Finalmente, ao compararmos as variáveis: solução irrigante e tempo, para o ensaio de curto prazo, não obtivemos diferenças estatísticas.

Na análise do período de médio prazo, que engloba os tempos de 1, 35 e 7 dias, o EDTA e o ácido cítrico apresentaram padrão citotóxico significativo em relação ao grupo controle, embora o ácido cítrico tenha sido menos citotóxico que o EDTA.

A concentração de células apontada pelo grupo controle foi cerca de 4,6 x $10^{5}$ células $/ \mathrm{mL}$, ao passo que o ácido cítrico reduziu pela metade a população de macrófagos $\left(2,3 \times 10^{5}\right.$ células $\left./ \mathrm{mL}\right)$. Já para o grupo do EDTA percebemos uma intensa diminuição celular, na ordem de 8,6 x 10 macrófagos/mL (Tabela 5.9).

De fato, os resultados de Malheiros (2000) concordam que o EDTA apresenta toxicidade elevada às células fibroblásticas, contudo divergem da opinião que o ácido cítrico seja citotóxico, exceto quando utilizados na concentração de $25 \%$ e diluição de $0,5 \%$. Para concentrações menores de ácido cítrico (10\% e 15\%), a autora não observou efeitos tóxicos sob a cultura de fibroblastos.

Contudo, vale ressaltar que os efeitos do EDTA a $17 \%$ são mais intensos que os do ácido cítrico a 15\%, independente do tipo celular analisado. 
À sua vez, Scelza et al. (2001) determinaram que o condicionamento de meio de cultura com EDTA-T e ácido cítrico a 10\%, na diluição de 1\%, impediram de forma equivalente o crescimento de fibroblastos no ensaio de longo prazo.

Vislumbrando o trabalho de Lovschall, Eiskjaer e Arenholt-Bindslev (2002), a confrontação dos diferentes resultados encontrados nas pesquisas mencionadas, até o momento, poderia residir no tipo de célula analisada e no método de interpretação. Somados a esses fatores, particularmente, somos convictos que a natureza, concentração e diluição das soluções avaliadas implicam na ambigüidade desses resultados.

Concordantes, Hennequin e Douillard (1995), Loel (1975), Yeung e Clarke (1983) atribuem boa tolerância tecidual ao ácido cítrico. Os autores admitem que por ser um ácido orgânico fraco haja menor irritação dos tecidos.

Contrariamente, Nunes (2002) verificou que a aplicação de concentrações mais elevadas de ácido cítrico (25\% e $50 \%$ ) no tecido subcutâneo de ratos contribuiu negativamente para o processo de reparação tecidual, sendo que a concentração de $50 \%$ potencializou a coagulação de proteínas, evitando a difusão pelo tecido.

A falta de parâmetros metodológicos e a utilização de diferentes concentrações das soluções poderiam indicar a diversidade dos resultados descritos acima.

Assim como no ensaio de curto prazo, evidenciamos uma queda constante da viabilidade celular em função do período de observação. Confrontando-se os tempos experimentais, observamos diferenças estatísticas entre os grupos 1 dia $\left(3,5 \times 10^{5}\right.$ células $/ \mathrm{mL}), 3$ dias $\left(2,8 \times 10^{5}\right.$ células $\left./ \mathrm{mL}\right), 5$ dias $\left(2,2 \times 10^{5}\right.$ células $\left./ \mathrm{mL}\right)$ e 7 dias $(1,9$ $\times 10^{5}$ células $/ \mathrm{mL}$ ). Somente entre os grupos 5 dias e 7 dias não houve significância estatística (Tabela 5.10). 
Quanto à interação irrigante $x$ tempo, não constatamos diferenças estatísticas.

É plausível que o consumo dos nutrientes contidos no meio de cultura seja também um dos responsáveis pelo decréscimo da viabilidade. Por melhor que o meio Mc Coy's $5 \mathrm{~A}$, enriquecido com $10 \%$ de soro fetal bovino, reproduza as condições ideais para a manutenção das células in vitro, a conduta de não substituição do meio de cultura adotada neste estudo poderia ter gerado o esgotamento de substrato e também o acúmulo de metabólitos provenientes do metabolismo dos macrófagos. Em termos gerais, ao analisarmos os dados da Tabela 5.8 e a Figura 5.7 referentes ao controle, observamos uma progressão descendente do número de células viáveis. Ao final de 7 dias, o grupo controle apresentou quase a metade da concentração celular inicial. Por outro lado, é impossível não atribuirmos os efeitos tóxicos comparativamente maiores ao EDTA a 17\% (redução drástica aos 3 dias) que ao ácido cítrico a $15 \%$.

Em suma, as soluções irrigadoras desempenham papel fundamental no preparo químico-cirúrgico, pois além de facilitar a ação dos instrumentos endodônticos, eliminam as sujidades, material orgânico, raspas de dentina excisadas do canal e por fim atuam na desinfecção do sistema radicular, tão bem evidenciados pelos estudos de anatomia interna propostos por Björndal et al. (1999), Vertucci (1984), Gomes, Rodrigues e Tancredo (1996), Peters et al. (2000), entre outros.

A compreensão das características químicas, físicas e biológicas determina a escolha de uma ou outra solução. Há de se convir que, até o presente momento, não dispomos de uma única solução capaz de exercer, com excelência, a remoção da contaminação orgânica e inorgânica dos canais e, portanto, a associação do hipoclorito de sódio a um agente quelante ou desmineralizante se faz necessário 
(BAUMGARTNER; IBAY, 1987; BAUMGARTNER; MADER, 1987; DI LENARDA; CADENARO; SBAIZERO, 2000; DOGAN; ÇALT, 2002; GAVINI, 1992; PETERS; BARBAKOW, 2000; YAMADA; ARMAS; GOLMAN, 1983).

A literatura é repleta de trabalhos que mostram a eficiência do EDTA e ácido cítrico na limpeza e aumento da permeabilidade dentinária, ao passo que a compatibilidade tecidual destes irrigantes não é bem definida.

Nossos resultados indicaram que independente da natureza das soluções avaliadas, ambas exerceram reações tóxicas à cultura de macrófagos, embora o EDTA tenha sido mais lesivo que o ácido cítrico. Talvez, a elevada toxicidade do EDTA possa ser explicada pela própria reação de quelação desta solução e também pelo acentuado decréscimo do $\mathrm{pH}$ do meio. Em contato com íons metálicos, duas reações químicas são desencadeadas: formação de um complexo (equação 1) e protonação (equação 2), exemplificadas pelas fórmulas:

$$
\begin{aligned}
& \mathrm{EDTAH}^{3}+\mathrm{Ca}^{2+}=\mathrm{EDTACa}^{2}+\mathrm{H} \\
& \mathrm{EDTAH}^{3}+\mathrm{H}=\mathrm{EDTAH}^{2}
\end{aligned}
$$

A medida que a reação ocorre, ácidos vão se acumulando e a protonação do EDTA prevalece. Como a molécula do EDTA é formado por 4 grupos carboxílicos, a dissociação iônica acontece em 4 etapas e, deste modo, mantém o pH do meio constantemente ácido (HÜLSMANN; HECKENDORFF; LENNON, 2003).

Por fim, os tecidos da região apical não são inertes aos sucessivos traumas gerados durante as manobras endodônticas. $O$ fato de trabalharmos com instrumentos endodônticos e substâncias químicas no interior do canal radicular causam reações inflamatórias nos tecidos periapicais, dadas a intimidade do ápice radicular com o ligamento e osso alveolar. Além disso, sabemos que nos casos de polpa mortificada, algumas cepas bacterianas podem se manter resistentes à terapia 
endodôntica e, desta forma, agir como um irritante direto. E, nesta ordem de idéias, a ocorrência de extravasamento das soluções irrigantes (EDTA ou ácido cítrico) alteram sobremaneira a atividade de macrófagos. Portanto, acreditamos que a somatória de estímulos poderia desencadear quadros inflamatórios agudos, caracterizado clinicamente pela presença de desconforto e dor pós-operatória.

Num segundo momento, o efeito residual das soluções irrigantes, em especial o EDTA, interfeririam na reparação tecidual e, eventualmente no sucesso clínico do tratamento endodôntico, pois do ponto de vista histológico, os macrófagos desempenham importantes funções na dinâmica reparacional, sendo responsáveis por comandar as demais células inflamatórias durante esta fase e também por produzir citocinas que estimulam a proliferação de fibroblastos.

Com base no exposto, sabemos que estudos citoquímicos são necessários para averiguarmos qual o exato mecanismo de defesa das células macrofágicas quando agredidas pelos irrigantes e, também, estudos in vivo devem ser propostos no intuito de avaliar se os resultados apontados apresentam relevância clínica. 


\section{CONCLUSÕES}

Pela análise da viabilidade imediata da cultura de macrófagos, concluímos:

- As soluções de EDTA a $17 \%$ e ácido cítrico a $15 \%$, nas diluições de 0,5\%, mostraram-se citotóxicas em relação ao controle.

- Independente da solução avaliada, a viabilidade celular no tempo de 0 horas foi, estatisticamente, mais elevada em comparação aos demais tempos avaliados.

Pela análise da viabilidade tardia da cultura de macrófagos, concluímos:

- Tanto as soluções de EDTA a 17\% quanto de ácido cítrico a 15\%, nas diluições de 0,5\%, apresentaram citotoxicidade.

- A solução de ácido cítrico a 15\% mostrou-se menos citotóxica em relação ao EDTA a 17\%.

- Independente da solução avaliada houve uma diminuição da viabilidade das células macrofágicas no decorrer do período experimental, revelando diferenças estatísticas, exceto para 5 dias e 7 dias. 


\section{REFERÊNCIAS ${ }^{1}$}

Akamine A, Hashiguchi I, Toriya Y, Maeda K. Immunohistochemical examination on the localization of macrophages and plasma cells induced in induced rat periapical lesions. Endod Dent Traumatol 1994;10:121-8.

Al-Omari MAO, Dummer PMH. Canal blockage and debris extrusion with eight preparation techniques. J Endod 1995;21:154-8.

Attalla MN, Calvert JM. Irritational properties of root canal medicaments. J Can Dent Assoc 1969;35:76-82.

Baumgartner JC, Brown CM, Mader CL, Peters DD, Shulman JD. A scanning electron microscopic evaluation of root canal debridment using saline, sodium hypoclorite and citric acid. J Endod 1984;10:525-31.

Baumgatner JC, Ibay AC. The chemical reactions of irrigants used for root canal debridment. J Endod 1987;13:47-51.

Baumgartner JC, Mader CL. A scanning electron microscopic evaluation of four root canal irrigation regimens. J Endod 1987;13:147-57.

Beltz RE, Torabinejad M, Pouresmail M. Quantitative analysis of the solubilizing action of MTDA, sodium hypochlorite, and EDTA on bovine pulp and dentin. J Endod 2003,29:334-7.

Bergmans L, Cleynenbreugel J, Wevers M, Lambrechts P. Mechanical root canal preparation with NiTi rotatory instruments: rationale, performance and safety. Status report for the American Journal of Dentistry. Am J Dent 2001;14:324-33.

Berutti E, Marini R, Angeretti A. Penetration ability on different irrigants into dentinal tubules. J Endod 1997;23:725-7.

\footnotetext{
${ }^{1}$ De acordo com Estilo Vancouver. Abreviatura de periódicos segundo base de dados MEDLINE.
} 
Bhambhani SM, Bolanos OR. Tissue reactions to endodôntico materials implanted in the mandibles of guinea pigs. Oral Surg Oral Med Oral Pathol 1993;76:493-50.

Björndal L, Carlsen O, Thuesen G, Darvann T, Kreiborg S. External and internal macromorphology in 3D-reconstructed maxillary molars using computerized X-ray microtomography. Int Endod J 1999;32:3-9.

Bombana AC, Paiva JG, Alvares S, Antoniazzi JH. Reação inflamatória do olho de coelho que se segue à instilação de alguns fármacos de uso endodôntico. Rev Assoc Paul Cir Dent 1974;28:216-23.

Brännström M. Smear layer: pathological and treatment considerations. Operative Dent 1984; Supl 3:35-42.

Browne RM, Tyas MJ. Biological testing of dental restorative materials in vitro- a review. J Oral Rehabil 1979;6:365-74.

Byström A, Sundqvist $G$. The antibactericidal action of sodium hypochlorite and EDTA in 60 cases of endodontic therapy. Int Endod J 1985;18:35-40.

Caba JY, Gavini G. Evaluación in vitro de la influncia de diferentes sustancias de irrigación final, sobre la permeabilidad dentinária del canal radicular. Endod Clin Prat Educ Res 1999;1:1-11.

Çalt S, Serper A. Time-dependent effects of EDTA on dentin surfaces. J Endod 2002;28:17-9.

Chan CP, Jeng JH, Hsieh CC, Lin CL, Lei D, Chang MC. Morphological alterations associated with the cytotoxic and cytostatic effects of citric acido $\mathrm{n}$ cultured human dental pulps. J Endod 1999; 25: 354-8.

Clark-Holke D, Drake D, Walton R, Rivera E, Guthmiller JM. Bacterial penetration through canals of endodontically treated teeth in the presence or absence of the smear layer. J Dent 2003;31:275-81.

Collier AC, Pritsos CA. The mitochondrial uncoupler dicumarol disrupts the MTT assay. Bioch Pharm 2003;66:281-7. 
Coolidge ED. Reaction of dog tissue to drugs used in root canal treatment. J Am Dent Assoc 1932;19:747-59.

Czonstkowsky M, Wilson EG, Holstein FA. The smear layer in endodontics. Dent Clin North Am 1990;34:13-25.

Deonízio MDA. Estudo comparativo da extrusão apical produzida por duas técnicas mecânico-rotatórias [Tese de Doutorado]. São Paulo: Faculdade de Odontologia da USP; 2001.

Deonízio MDA, Gavini G, Pantarolo R. Estudo comparativo da extrusão apical, produzida por duas diferentes técnicas mecânico-rotatórias (Res. Pa-064). Pesq Odontol Bras 2002;16:130.

Di Lenarda R, Cadenaro M, Sbaizero O. Effectiveness of $\mathrm{mol} \mathrm{L}^{-1}$ citric acid and $15 \%$ EDTA irrigation on smear layer removal. Int Endo J 2000;33:46-52.

Dogan $\mathrm{H}$, Çalt $\mathrm{S}$. Effects of chelating agents and sodium hypoclorite on mineral content of root dentin. J Endod 2001;27:578-80.

Engström B, Spangberg L. studies on root canal medicaments. III citotoxic effect of dentine dissolving medicaments. Acta Odontol Scand 1967;25:187-90.

European Comitee for Standardization. EN 540: Clinical investigation of medical devices from human subjects. Brussels: ECS; 1996.

Ferraz CC, Gomes BP, Zaia AA, Teixeira FB, Souza-Fill FJ. Apical extrusion of debris and irrigants using two hand and three engine-driven instrumentation techniques. Int Endod J 2001;34:354-8.

Fleit SA, Fleit HB, Zolla-Pazner S. Culture and recovery of macrophages and cell lines from tissue culture-treated and -untreated plastic dishes. J Immunol Methods 1984;68:119-29.

Freshney RI. Measurement of cytotoxicity and viability. $2^{\text {nd }}$ ed. In: Culture of animal cells: a manual of basic technique. New York: Willy- Liss;1990. p. 7-13.

Garberoglio R, Becce C. Smear layer removal by root canal irrigants. Oral Surg Oral Med Oral Pathol Oral Radiol 1994;78:359-67. 
Gavini G. Avaliação in vitro da limpeza da parede do canal radicular (terço apical), após o preparo químico-mecânico, valendo-se da microscopia eletrônica de varredura, tendo como fonte de variação a solução irrigadora e seu volume [Dissertação de Mestrado]. São Paulo: Faculdade de Odontologia da USP; 1992.

Gavini G. Análise in vitro da limpeza do terço apical do canal radicular, quanto à remoção do magma dentinário, à luz da microscopia eletrônica de varredura, tendo como fonte de variação o regime de irrigação e as soluções irrigantes [Tese de Doutorado]. São Paulo: Faculdade de Odontologia da USP; 1994.

Gessani S, Fantuzzi L, Puddu P, Belardelli F. Purification of macrophages. In: Paulnock DM. Macrophages: a practical approach. New York: Oxford University Press Inc.; 2000. p. 31-60.

Goldberg F, Abramovich A. Analysis of the effect of EDTAC on the dentinal walls of the root canal. J Endod 1977;3:101-5.

Goldberg F, Spielberg C. The effect of EDTAC and the variation of its working time analysed with scanning electron microscopy. Oral Surg Oral Med Oral Pathol Oral Radiol 1982;53:74-7.

Gomes BPFA, Rodrigues $\mathrm{HH}$, Tancredo N. The use of a modelling technique to investigate the root canal morphology of mandibular incisors. Int Endod $\mathrm{J}$ 1996;29:29-36.

Haglund R, He J, Jarvis J, Safavi KE, Spangberg LSW, Zhu Q. Effects of root end filling materials on fibroblasts and macrophages in vitro. Oral Surg Oral Med Oral Pathol 2003;95:739-45.

Handel-Fernandez ME, Lopez DM. Isolation of macrophages from tissues, fluids and immune response sites. In: Paulnock DM. Macrophages: a practical approach. New York: Oxford University Press Inc.; 2000. p. 1-30.

Harrison JW, Svec TA, Baumgartner JC. Analysis of clinical toxicity of endodontic irrigants. J Endod 1978;4:6-11.

Hauman CHJ, Love RM. Biocompatibility of dental materials used in contemporary endodontic therapy: a review. Part 1. Intracanal drugs and substances. Int Endod J 2003;36:75-85. 
Haznedaroglu F. Efficacy of various concentrations of citric acid at different $\mathrm{pH}$ values for smear layer removal. Oral Surg Oral Med Oral Pathol 2003;96:340-4.

Heling I, Chandler NP. Antimicrobial effect of irrigating combinations within dentinal tubules. Int Endod J 1998;31:8-14.

Hennequin M, Pajot J, Avignant D. Effects of different $\mathrm{pH}$ values of citric acid solutions on the calcium and phosphorus contents of human root dentin. J Endod 1994;20:551-4.

Hennequin M, Douillard Y. Effects of citric acid treatment on the Ca, $\mathrm{P}$ and $\mathrm{Mg}$ contents of human dental roots. J Clin Periodontol 1995;22:550-7.

Hülsmann M, Heckendorff M, Schäfers F. Comparative in vitro evaluation of three chelator pastes. Int Endod J 2002;35:668-79.

Hülsmann M, Heckendorff M, Lennon À. Chelating agents in root canal treatment: mode of action and indications for their use. Int Endod J 2003;36:810-30.

Hyakuna K, Yamamuro T, Kotoura Y, Kakutani Y, Kitsugi T, Takagi H, Oka M, Kokubo M. The influence of calcium phosphate ceramics and glass-ceramics on cultured cells and their surrounding media. J Biomed Mater Res 1989;23:1049-66.

International Organization for Standardization 1997. ISO 7405: dentistry- preclinical evaluation of the biocompatibility of medical devices used in dentistry- test methods for dental materials. Genova: ISO; 1997.

Jackson AM, Alexandroff AB, Lappin MB, Esuvaranathan K, James K, Chisholm GD. Immunology 1994:81-120.

Kawahara $\mathrm{H}$, Yamagami A, Nakamura M. Biological testing of dental materials by means of tissue culture. Int Dent J 1968;9:443-67.

Kawashima N, Okiji T, Kosaka T, Suda H. Kinetics of macrophages and lymphoid cells during the development of experimentally induced periapical lesions in rat molars: a quantitative immunohistochemical study. J Endod 1996;22:311-6. 
Kopp W, Schwarting R. Differentiation of T lymphocyte subpopulations, macrophages, and HLA-DR-restricted cells of apical granulation tissue. J Endod 1989;15:72-5.

Kostoryz E, Eick JD, Chappelow CC, Glaros AG, Wetmore L, Yourtee DM. In vitro effect of light-cure dental adhesive on IL-6 release from LPS-stimulated and unstimulated macrophages. J Biomed Mat Res 2003;65A:89-94.

Koulaouzidou EA, Margelos J, Beltes P, Kortsaris A. Cytotoxic effects of different concentrations of neutral and alkaline EDTA solutions used as root canal irrigants. $J$ Endod 1999;25:21-3.

Lara VS, Figueiredo F, Dilva TA, Cunha FQ. Dentin-induced in vivo inflamatory response and in vitro activation of murine macrophages. J Dent Res 2003;82:460-5.

Leirskar L, Helgeland K. Mechanism of toxicity of dental materials. Int Endod J $1981 ; 14: 42-8$.

Liolios E, Economides N, Parissis-Meissimeris S, Boutsioukis A. The effectiveness of three irrigating solutions on root canal cleaning after hand and mechanical preparation. Int Endod J 1997;30:51-7.

Loel A. Use of acid cleanser in endodontics therapy. J Am Dent Assoc 1975;90:14851.

Lovschall H, Eiskjaer M, Arenholt-Bindslev D. Formaldehyde cytotoxicity in three human cell types assessed in three different assays. Toxicol in vitro 2002;16:63-9.

Malheiros CF, Gavini G. Efeito desmineralizador do ácido cítrico em diferentes concentrações e períodos de tempo. Rev Pós Grad Fac Odont USP 1998;5:64-8.

Malheiros CF. Avaliação comparativa da citotoxicidade in vitro de EDTA e ácido cítrico aplicados em fibroblastos cultivados [Dissertação de Mestrado]. São Paulo: Faculdade de Odontologia da USP; 2000.

Masillamoni CRM, Kettering JD, Torabinejad M. The biocompatibility of some root canal medicaments and irrigants. Int Endod J 1981;14:115-20. 
Mendes STO, Sobrinho APR, Carvalho AT, Côrtes MIS, Vieira LQ. In vitro evaluation of the cytotoxicity of two root canal sealers on macrophage activity. J Endod 2003;29:95-9.

Mehra P, Clancy C, Wu J. Formation of a facial hematoma during endodonic therapy. J Am Dent Assoc 2000,131:67-71.

Mestrener SR, Holland R, Dezan Jr E. Influence of age on the behavior of dental pulp of dog teeth after capping with an adhesive system or calcium hydroxide. Dent Traumatol 2003;19:255-61.

Metzger Z, Berg D, Dotan M. Fibroblast growth in vitro suppressed by LPS-ativated macrophages. Reversal of suprpression by hydrocortisone. J Endod 1997;23:517-21.

Metzger Z. Macrophages in periapical lesions. Endod Dent Traumatol 2000;16:1-8.

Mossman T. Rapid colorimetric assay for cellular growth and survival: application to proliferation and cytotoxicity assay. J Immunol Methods 1983;65:55-63.

Murphy $C$, Newshome $P$. Macrophage-mediated lysis of a $\beta$-cell line, tumor necrosis factor- $\alpha$ release from bacillus Calmatte-Guérin (BCG)-activated murine macrophages and interleukin-8 release from human monocytes are dependent on extracellular glutamine concentration and glutamine metabolism. Clin Sci 1999;96:89-97.

Nery MJ, Souza V, Holland R. Reação do coto pulpar e tecidos periapicais de dentes de cães a algumas substâncias empregadas no preparo biomecânico dos canais radiculares. Rev Fac Odont Arac 1974;3:245-54.

Nikolaus BE, Wayman BE, Encinas E. The bactericidal effect of citric and sodium hypoclorite on anaerobic bacteria. J Endod 1988;14:31-4.

Nunes MRL. Avaliação comparativa dos efeitos derivados da aplicação de algumas substâncias irrigadoras de uso endodôntico no conjuntivo subcutâneo de ratos [Tese de Doutorado]. São Paulo: Faculdade de Odontologia da USP; 2002.

Nygaard-Ostby B. Chelation in root canal therapy. Odontol Tidskr 1957;65:1-11.

Osorio RM, Hefti A, Vertucci FJ, Shawley A. Cytotoxicity of endodontic materials. J Endod 1998;24:91-6. 
Orstavik D, Haapasalo M. Disinfection by endodontic irrigants and dressings of experimentally infected dentinal tubules. Endod Dent Traumatol 1990;6:142-9. Pashley DH. Smear layer: physiological considerations. Operative Dent 1984;Supl 3:13-29.

Pécora JD, Cussioli AL, Guerisoli DMZ, Marchesan MA, Sousa-Neto MD, BrugneraJunior, A. Evaluation of Er:YAG laser and EDTAC on dentin adhesion of six endodontic sealers. Braz Dent J 2001,12:27-30.

Peters OA, Barbakow F. Effects of irrigation on debris and smear layer on canal walls prepared by two rotatory techniques: a scanning electron microscopic study. J Endod 2000;26:6-10.

Peters OA, Laib A, Rüegsegger $P$, Barbakow $F$. Three-dimensional analysis of root canal geometry by high-resolution computed tomography 2000,79:1405-9.

Piatelli A, Artese L, Rosini S, Quaranta M, Musiani P. Immune cells in periapical granuloma: morphological and immunohistochemical characterization. J Endod 1991;17:26-9.

Sadeghein A, Bolhari B, Sarafnejad A. A comparison of the effect of three endodontic sealers on adherence of mouse peritoneal macrophages. J Calif Dent Assoc 2001;29:673-7.

Santos E, Jaeger M, Pinto ACG, Araújo VC. Estudo in vitro da pasta Guedes-Pinto em fibroblastos embrionários e pulpares (Res 38). RPG 1996;3:297.

Santos EM, Jaeger MMM, Guedes-Pinto, AC. Caracterização de modelo de macrófagos em cultura para testes de toxicidade (Res PA 218). Pesqui Odontol Bras 2000;14 Supl:87.

Scarano A, Manzon L, Di Giorgio R, Orsini G, Tripodi D, Piattelli A. Direct capping with four different materials in humans: histological analysis of odontoblast activity. $J$ Endod 2003;29:729-34.

Scelza MFZ, Antoniazzi JH, Scelza P. Efficacy of final irrigation- a scanning electron microscopic evaluation. J Endod 2000;26:355-8. 
Scelza MF, Pinheiro Daniel RLD, Santos EM, Jaeger MMM. Cytotoxic effects of 10\% citric acid and EDTA-T used as root canal irrigants: an in vitro analysis. J Endod 2001;27:741-3.

Scelza MFZ, Teixeira AM, Scelza P. Decalcifying effect of EDTA-T, 10\% citric acid and $17 \%$ EDTA on root canal dentin. Oral Surg Oral Med Oral Pathol Oral Radiol 2003;95:234-6.

Schmalz G, Sharaf M. Die verwendung unterschied-licher zellarten im agardiffusions-test. Z Zahnärztl Implantol 1988;4:240-45.

Schmalz G. Use of cell cultures for toxicity testing of dental materials- advantages and limitations. J Dent 1994;2 Supl:6-11.

Segura JJ, Calvo JR, Guerrero JM, Sampedro C, Jimenez A, Llamas R. The disodium salt of EDTA inhibits the binding of vasoactive intestinal peptide to macrophage membranes: endodontic implications. J Endod 1996;22:337-40.

Segura JJ, Calvo JR, Guerrero JM, Jimenez-Planas A, Sampedro C, Llamas R. EDTA inibits in vitro substrate adherence capacity of macrophages: endodontic implications. J Endod 1997;23:205-8.

Segura-Egea JJ, Jiménez-Rubio A, Rios-Santos JV, Velasco-Ortega E, CalvoGutierrez JR. In vitro inhinitory effect of EGTA on macrophage adhesion: endodontic implications. J Endod 2003;29:211-3.

Serper A, Çalt S, Dogan AL, Guc Dicle, Özçelik B, Kuraner T. Comparison of the cytotoxic effects and smear layer removing capacity of oxidative potencial water, $\mathrm{NaOCl}$ and EDTA. J Oral Sci 2001;43:233-8.

Serper A, Çalt S. The demineralizing effects of EDTA at different concentrations and pH. J Endod 2002;28:501-2.

Siqueira JF, Batista MMD, Fraga, RC, Uzeda M. Antibactericidal effects of endodontic irrigants on black pigmented gram-negative anaerobes and facultative bacteria. J Endod 1998;24:414-6.

Sjögren U, Sundqvist G, Lerner UH. Gutta-percha-stimulated mouse macrophages release factors that active the bone resorptive system of mouse calvarial bone. Eur $\mathrm{J}$ Oral Sci 1998;106:872-81. 
Smith JJ, Wayman B. An evaluation of the antimicrobial effectiveness of citric acid as a root canal irrigant. J Endod 1986;12:54-8.

Spangberg L. Biological effects of root canal filling materials. Odonto Rev 1969;20:123-32.

Spangberg L. Kinetic and quantitative evaluation of material cytotoxicity in vitro. Oral Surg Oral Med Oral Pathol Oral Radiol 1973;35:389-401.

Syrjänen S, Nilner K, Hensten-Pettersen A. In vitro testing of dental materials by means of macrophage cultures I: Methodological aspects. J Biomed Mater Res 1986;20:1111-23.

Takeda FH, Harashima T, Kimura Y, Matsumoto K. A comparative study of the removal of smear layer by three endodontic irrigants and two types of laser. Int Endod J 1999;32:32-9.

Torneck CD. Reaction of hamster tissue to drug used in sterilization of the root canal. Oral Surg Oral Med Oral Pathol 1961;14:730-47.

Vertucci FJ. Root canal anatomy of the human permanent teeth. Oral Surg Oral Med Oral Pathol 1984;58:589-99.

Villegas JC, Yoshioka T, Kobayashi C, Suda H. Obturation of accessory canals after four different final irrigation regimes. J Endod 2002;28:534-6.

Wayman BE, Kopp WM, Pinero GJ, Lazzari EP. Citric and latic acids as root canal irrigants in vitro. J Endod 1979;5:258-65.

Yamada RS, Armas A, Goldman M, Lin PS. A sanning electron microscopic comparison of a high volume final flush with several irrigating solutions: Part 3. J Endod 1983;9:137-42.

Yamaguchi M, Yoshida K, Suzuki R, Nakamura H. Root canal irrigation with citric acid solution. J Endod 1996;22:27-9.

Yesiloy C, Whitaker E, Cleveland D, Phillips E, Trope M. Antimicrobial and toxic effects of established and potencial root canal irrigants. J Endod 1995;21:513-5. 
Yeung S, Clarke N. Pulpal effect of citric acid applied topically to root surfaces. Oral Surg Oral Med Oral Pathol 1983;56:317-20.

Yoshida T, Shibata T, Shinohara T, Gomyo S, Sekine I. Clinical evaluation of the efficacy of EDTA solution as na endodontic irrigant. J Endod 1995;21:592-3.

Zhang W, Torabinejad M, Li Y. Evaluation of cytotoxicity of MTAD using the MTTtetrazolium method. J Endod 2003;29:654-7. 


\section{APÊNDICE A}

APÊNDICE A1 - Dados da absorbância $(\mathrm{nm})$ relativos ao ensaio experimental 1

\begin{tabular}{clllllll}
\hline & 0 Horas & 6 Horas & 12 Horas & 24 Horas & 3 Dias & 5 Dias & 7 Dias \\
\hline Controle & & & & & & & \\
\hline 1 & 0,420 & 0,330 & 0,294 & 0,332 & 0,312 & 0,260 & 0,238 \\
2 & 0,362 & 0,366 & 0,570 & 0,331 & 0,310 & 0,263 & 0,239 \\
3 & 0,411 & 0,343 & 0,231 & 0,335 & 0,311 & 0,265 & 0,234 \\
& & & & & & & \\
X & 0,3980 & 0,3460 & 0,3650 & 0,3330 & 0,3110 & 0,2630 & 0,2370 \\
EDTA & & & & & & & \\
\hline 1 & 0,289 & 0,244 & 0,215 & 0,192 & 0,137 & 0,107 & 0,114 \\
2 & 0,275 & 0,235 & 0,220 & 0,206 & 0,131 & 0,104 & 0,112 \\
3 & 0,285 & 0,257 & 0,218 & 0,202 & 0,127 & 0,132 & 0,119 \\
X & 0,2830 & 0,2450 & 0,2180 & 0,2000 & 0,1320 & 0,114 & 0,115
\end{tabular}

Ác. cítrico

\begin{tabular}{|c|c|c|c|c|c|c|c|}
\hline 1 & 0,277 & 0,225 & 0,233 & 0,222 & 0,211 & 0,191 & 0,178 \\
\hline 2 & 0,275 & 0,217 & 0,218 & 0,190 & 0,206 & 0,184 & 0,181 \\
\hline 3 & 0,263 & 0,238 & 0,230 & 0,198 & 0,205 & 0,163 & 0,171 \\
\hline$X$ & 0,2720 & 0,2270 & 0,2270 & 0,2030 & 0,2070 & 0,1790 & 0,1770 \\
\hline Padrão 01 & Branco & $10^{3}$ & $10^{4}$ & $10^{5}$ & $5 \times 10^{5}$ & $7,5 \times 10^{5}$ & $10^{6}$ \\
\hline $0,6,12$ & 0,146 & 0,158 & 0,154 & 0,266 & 0,405 & 0,441 & 0,552 \\
\hline horas & 0,162 & 0,154 & 0,161 & 0,238 & 0,419 & 0,458 & 0,562 \\
\hline$x$ & 0,154 & 0,156 & 0,157 & 0,252 & 0,412 & 0,449 & 0,557 \\
\hline Padrão 02 & Branco & $10^{3}$ & $10^{4}$ & $10^{5}$ & $5 \times 10^{5}$ & $7,5 \times 10^{5}$ & $10^{6}$ \\
\hline 24 horas & 0,133 & 0,132 & 0,132 & 0,208 & 0,429 & 0,553 & 0,649 \\
\hline 3 dias & 0,133 & 0,135 & 0,133 & 0,214 & 0,389 & 0,563 & 0,630 \\
\hline$X$ & 0,133 & 0,133 & 0,132 & 0,211 & 0,409 & 0,558 & 0,639 \\
\hline Padrão 03 & Branco & $10^{3}$ & $10^{4}$ & $10^{5}$ & $5 \times 10^{5}$ & $7,5 \times 10^{5}$ & $10^{6}$ \\
\hline 5 dias & 0,111 & 0,118 & 0,115 & 0,184 & 0,321 & 0,475 & 0,459 \\
\hline 7 dias & 0,121 & 0,116 & 0,110 & 0,187 & 0,351 & 0,420 & 0,549 \\
\hline X & 0,116 & 0,117 & 0,112 & 0,185 & 0,336 & 0,447 & 0,504 \\
\hline
\end{tabular}


APÊNDICE A2 - Grupo-padrão 1, referente aos períodos de 0, 6 e 12 horas do ensaio experimental 1

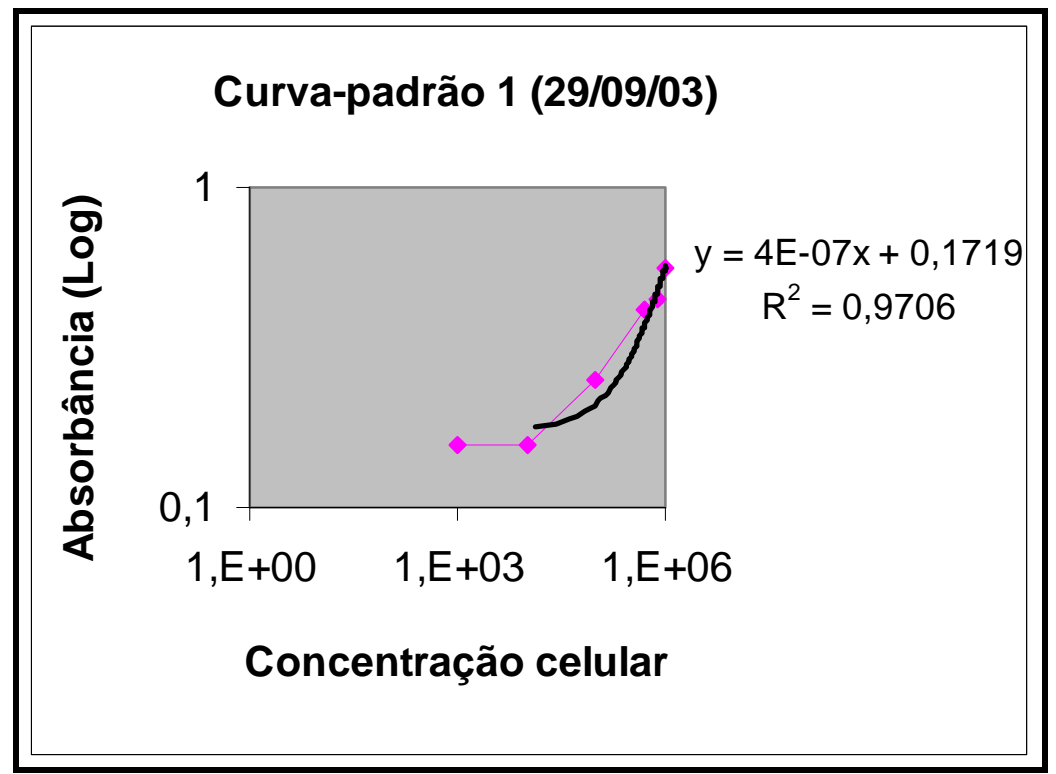

APÊNDICE A3 - Grupo-padrão 2, referente aos períodos de 1 e 3 dias do ensaio experimental 1

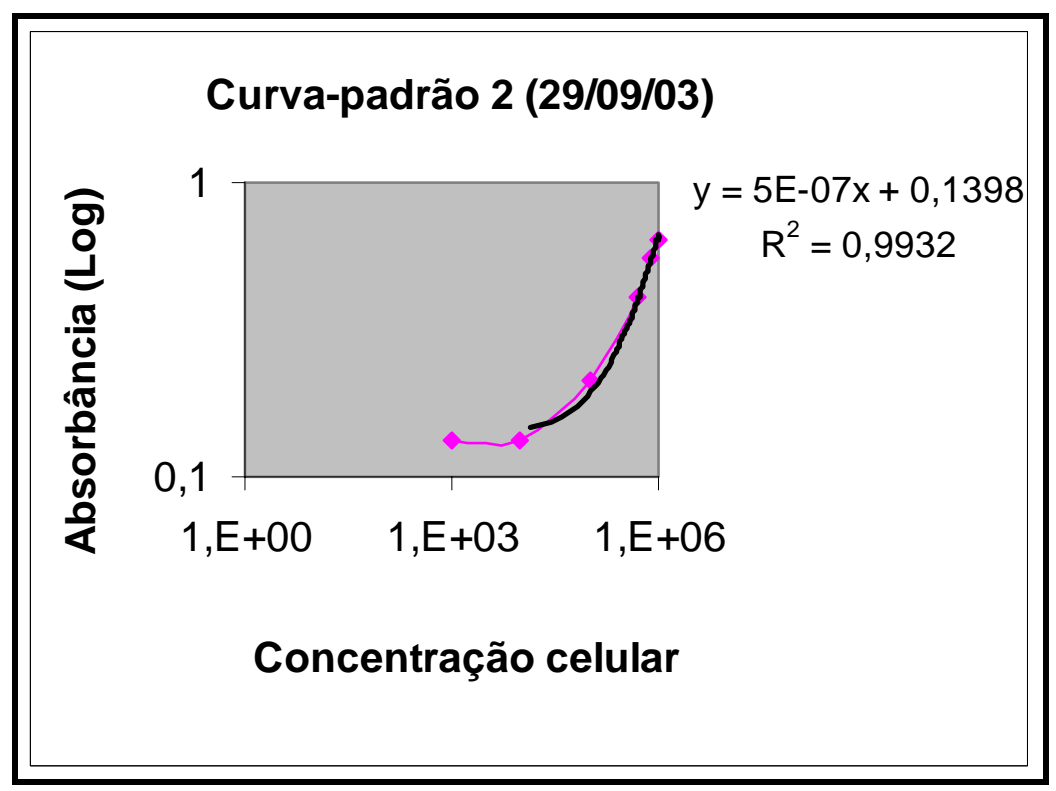


APÊNDICE A4 -Grupo-padrão 3, referente aos períodos de 5 e 7 dias do ensaio experimental 1

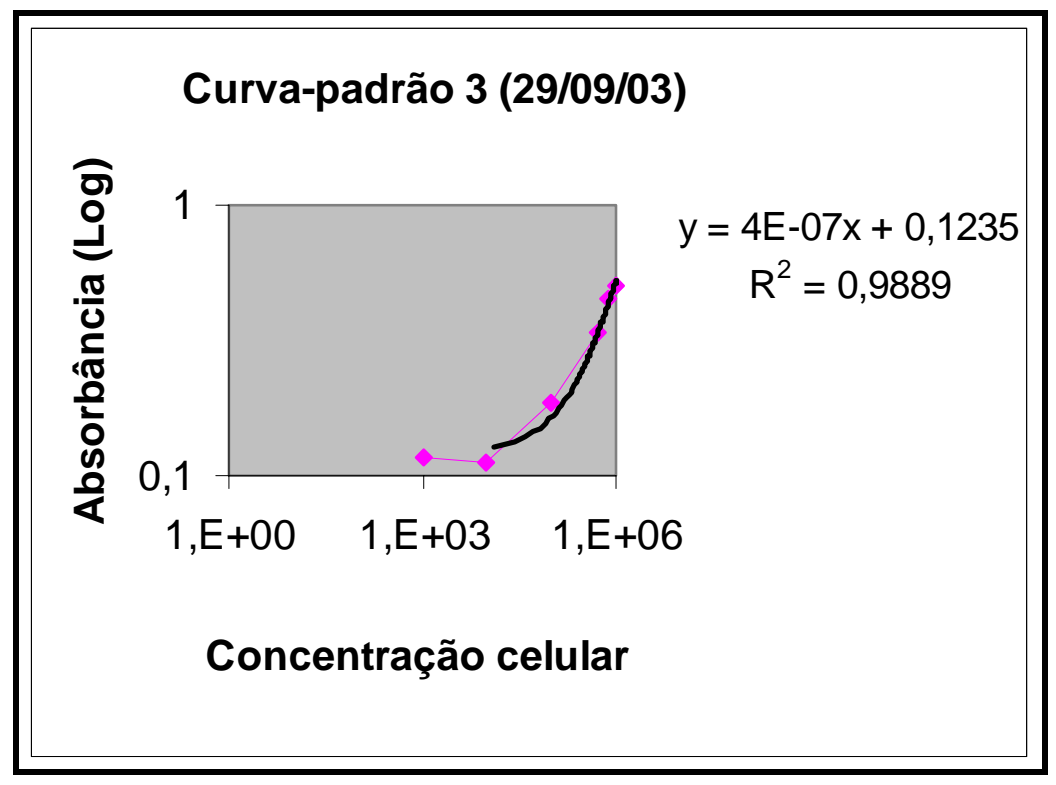


APÊNDICE A5 - Valores da absorbância média (nm) e concentração de macrófagos em função da solução e tempo do ensaio experimental 1

\begin{tabular}{|c|c|c|c|c|c|c|}
\hline \multirow[b]{2}{*}{ Tempo } & \multicolumn{2}{|c|}{ Controle } & \multicolumn{2}{|c|}{ EDTA } & \multicolumn{2}{|c|}{ Ácido cítrico } \\
\hline & $\begin{array}{c}\text { Absorbância } \\
\text { média } \\
(\mathrm{nm})\end{array}$ & $\begin{array}{l}\text { Concentração } \\
\text { celular } \\
\text { (n. }{ }^{\circ} \text { cél/ mL) }\end{array}$ & $\begin{array}{c}\text { Absorbância } \\
\text { média } \\
(\mathrm{nm})\end{array}$ & $\begin{array}{l}\text { Concentração } \\
\text { celular } \\
\text { (n. }{ }^{\circ} \text { cél/ mL) }\end{array}$ & $\begin{array}{c}\text { Absorbância } \\
\text { média } \\
(\mathrm{nm})\end{array}$ & $\begin{array}{l}\text { Concentração } \\
\text { celular } \\
\text { (n. }{ }^{\circ} \text { cél/ mL) }\end{array}$ \\
\hline Inicial (-1) & 0,3980 & 565.250 & 0,3980 & 565.250 & 0,3980 & 565.250 \\
\hline 0 horas & 0,3980 & 565.250 & 0,2830 & 277.750 & 0,2720 & 250.250 \\
\hline 6 horas & 0,3463 & 436.000 & 0,2453 & 183.500 & 0,2270 & 137.750 \\
\hline 12 horas & 0,3650 & 482.750 & 0,2180 & 115.250 & 0,2270 & 137.750 \\
\hline 1 dia & 0,3330 & 386.400 & 0,2000 & 120.400 & 0,2030 & 126.400 \\
\hline 3 dias & 0,3310 & 342.400 & 0,1320 & -15.600 & 0,2070 & 134.400 \\
\hline 5 dias & 0,2630 & 348.750 & 0,1140 & -23.750 & 0,1790 & 138.750 \\
\hline 7 dias & 0.2370 & 283.750 & 0,1150 & -21.250 & 0,1770 & 133.750 \\
\hline
\end{tabular}

APÊNDICE A6 - Curva de viabilidade celular (concentração de macrófagos) em função da solução e tempo do ensaio experimental 1

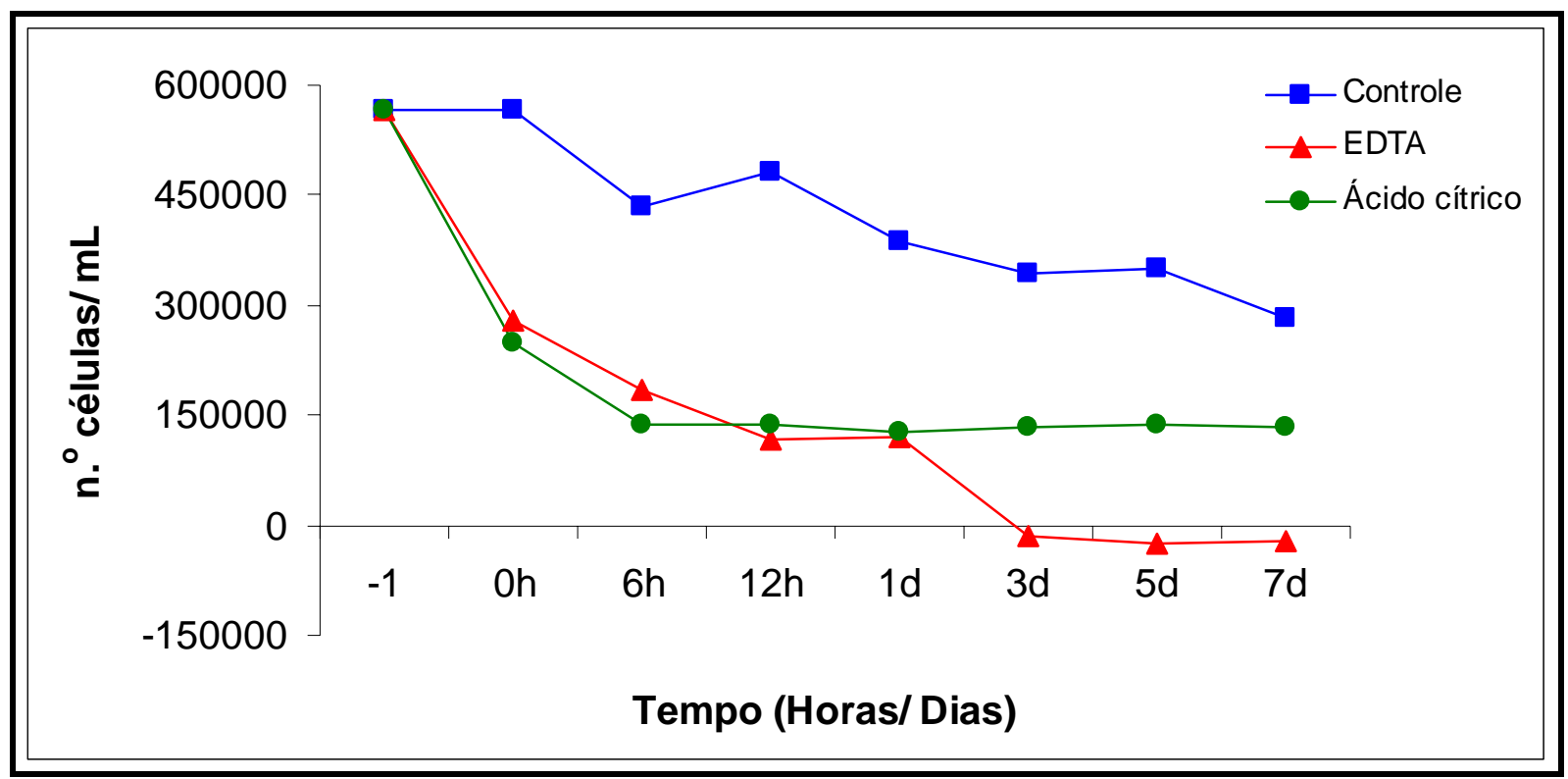




\section{APÊNDICE B}

APÊNDICE B1 - Dados da absorbância (nm) relativos ao ensaio experimental 2

\begin{tabular}{ccllllll}
\hline & 0 Horas & 6 Horas & 12 Horas & 24 Horas & 3 Dias & 5 Dias & 7 Dias \\
\hline Controle & & & & & & & \\
\hline 1 & 0,385 & 0,334 & 0,329 & 0,341 & 0,333 & 0,314 & 0,312 \\
2 & 0,392 & 0,327 & 0,331 & 0,371 & 0,336 & 0,322 & 0,328 \\
3 & 0,378 & 0,323 & 0,324 & 0,356 & 0,345 & 0,326 & 0,320 \\
& & & & & & & \\
X & 0,385 & 0,328 & 0,328 & 0,356 & 0,338 & 0,321 & 0,320 \\
& & & & & & & \\
\hline EDTA & & & & & & & \\
\hline 1 & 0,362 & 0,280 & 0,242 & 0,211 & 0,167 & 0,165 & 0,163 \\
2 & 0,337 & 0,275 & 0,244 & 0,206 & 0,169 & 0,165 & 0,159 \\
3 & 0,344 & 0,275 & 0,241 & 0,208 & 0,163 & 0,170 & 0,160 \\
X & 0,348 & 0,277 & 0,242 & 0,208 & 0,166 & 0,167 & 0,161
\end{tabular}

Ác. cítrico

\begin{tabular}{|c|c|c|c|c|c|c|c|}
\hline 1 & 0,322 & 0,274 & 0,269 & 0,294 & 0,263 & 0,233 & 0,206 \\
\hline 2 & 0,319 & 0,275 & 0,267 & 0,284 & 0,266 & 0,227 & 0,207 \\
\hline 3 & 0,321 & 0,272 & 0,268 & 0,276 & 0,265 & 0,230 & 0,206 \\
\hline$X$ & 0,321 & 0,274 & 0,268 & 0,285 & 0,265 & 0,230 & 0,206 \\
\hline Padrão 01 & Branco & $10^{3}$ & $10^{4}$ & $10^{5}$ & $5 \times 10^{5}$ & $7,5 \times 10^{5}$ & $10^{6}$ \\
\hline $0,6,12$ & 0,180 & 0,197 & 0,260 & 0,261 & 0,402 & 0,485 & 0,546 \\
\hline horas & 0,183 & 0,194 & 0,260 & 0,256 & 0,383 & 0,510 & 0,546 \\
\hline X & 0,181 & 0,195 & 0,260 & 0,258 & 0,392 & 0,497 & 0,546 \\
\hline Padrão 02 & Branco & $10^{3}$ & $10^{4}$ & $10^{5}$ & $5 \times 10^{5}$ & $7,5 \times 10^{5}$ & $10^{6}$ \\
\hline 24 horas & 0,184 & 0,198 & 0,260 & 0,264 & 0,398 & 0,487 & 0,553 \\
\hline 3 dias & 0,19 & 0,196 & 0,258 & 0,261 & 0,401 & 0,475 & 0,544 \\
\hline$X$ & 0,187 & 0,197 & 0,259 & 0,262 & 0,399 & 0,481 & 0,548 \\
\hline Padrão 03 & Branco & $10^{3}$ & $10^{4}$ & $10^{5}$ & $5 \times 10^{5}$ & $7,5 \times 10^{5}$ & $10^{6}$ \\
\hline 5 dias & 0,112 & 0,113 & 0,110 & 0,184 & 0,331 & 0,394 & 0,525 \\
\hline 7 dias & 0,111 & 0,110 & 0,111 & 0,184 & 0,351 & 0,442 & 0,519 \\
\hline $\mathrm{X}$ & 0,111 & 0,111 & 0,110 & 0,184 & 0,341 & 0,418 & 0,522 \\
\hline
\end{tabular}


APÊNDICE B2 - Grupo-padrão 1, referente aos períodos de 0, 6 e 12 horas do ensaio experimental 2

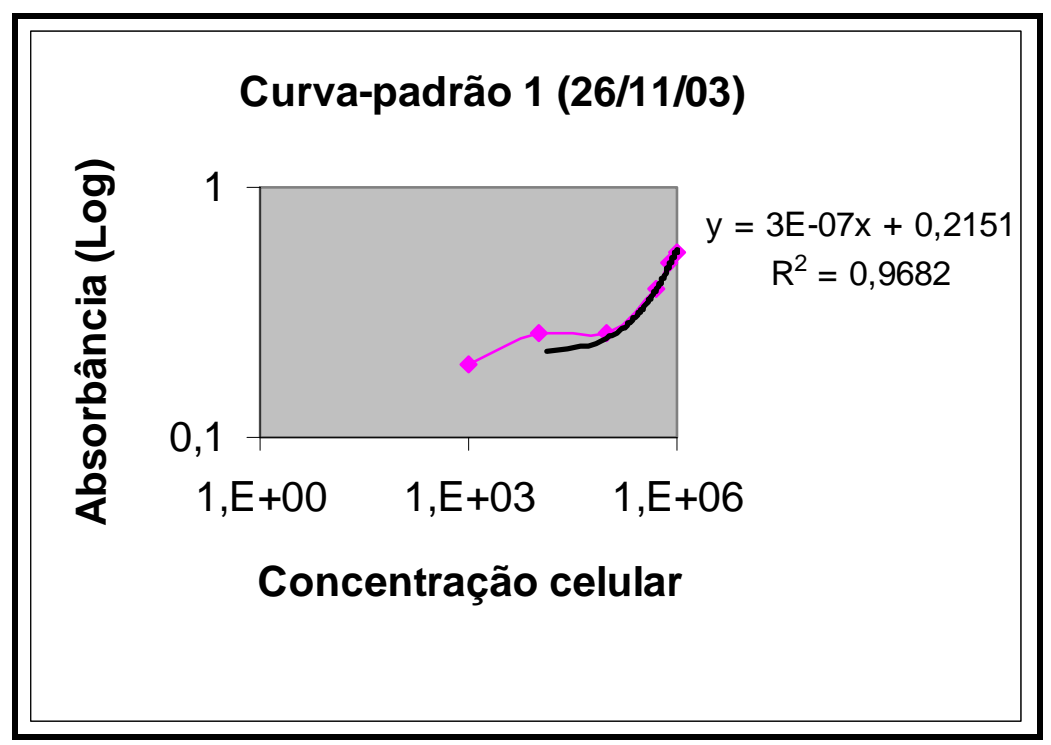

APÊNDICE B3 - Grupo-padrão 1, referente aos períodos de 1 e 3 dias do ensaio experimental 2

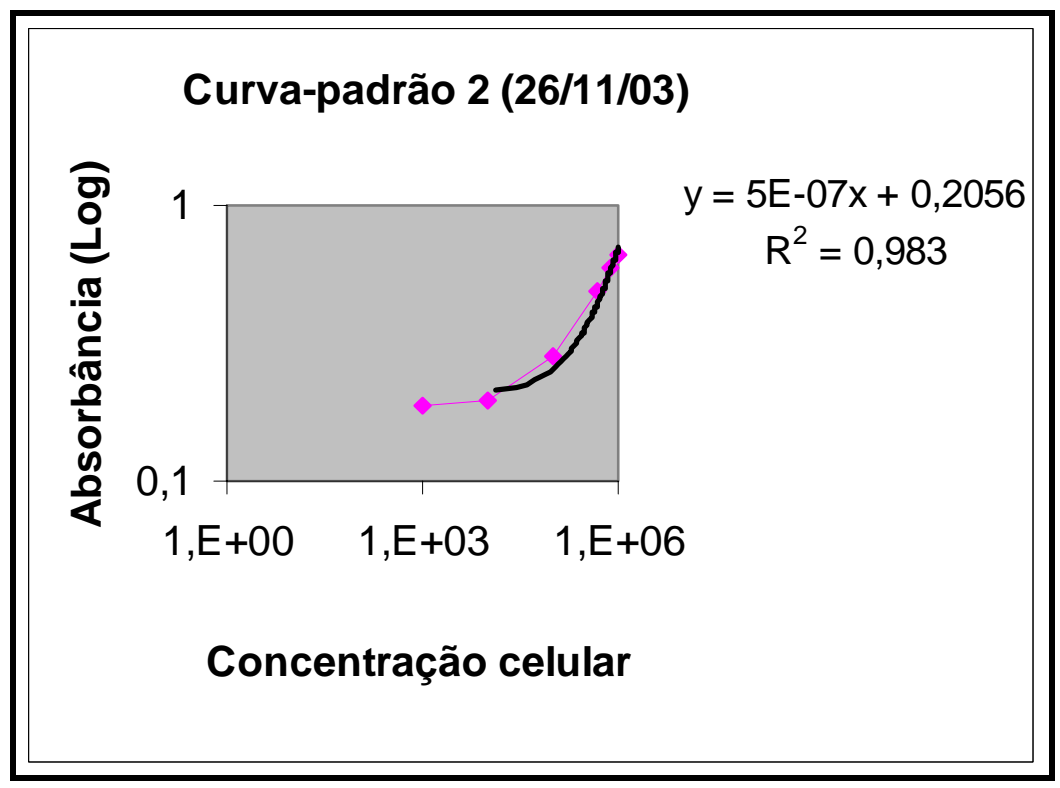


APÊNDICE B4 - Grupo-padrão 1, referente aos períodos de 5 e 7 dias do ensaio experimental 2

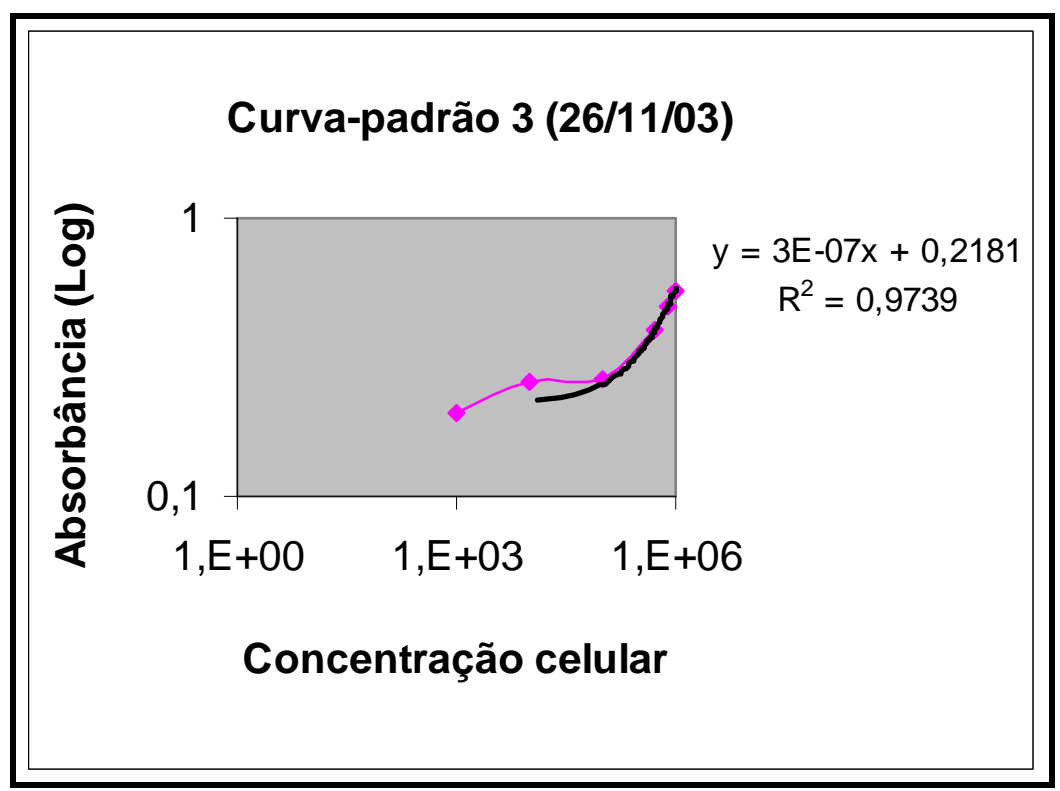


APÊNDICE B5 - Valores da absorbância média (nm) e concentração de macrófagos em função da solução e tempo do ensaio experimental 2

\begin{tabular}{|c|c|c|c|c|c|c|}
\hline \multirow[b]{2}{*}{ Tempo } & \multicolumn{2}{|c|}{ Controle } & \multicolumn{2}{|c|}{ EDTA } & \multicolumn{2}{|c|}{ Ácido cítrico } \\
\hline & $\begin{array}{l}\text { Absorbância } \\
\text { média } \\
(\mathrm{nm})\end{array}$ & $\begin{array}{l}\text { Concentração } \\
\text { celular } \\
\text { (n.o cél/ mL) }\end{array}$ & $\begin{array}{c}\text { Absorbância } \\
\text { média } \\
(\mathrm{nm})\end{array}$ & $\begin{array}{l}\text { Concentração } \\
\text { celular } \\
\text { (n. }{ }^{\circ} \text { cél/ mL) }\end{array}$ & $\begin{array}{l}\text { Absorbância } \\
\text { média } \\
(\mathrm{nm})\end{array}$ & $\begin{array}{l}\text { Concentração } \\
\text { celular } \\
\text { (n. }{ }^{\circ} \text { cél/ mL) }\end{array}$ \\
\hline Inicial (-1) & 0,3850 & 566.333 & 0,3850 & 566.333 & 0,3850 & 566.333 \\
\hline 0 horas & 0,3850 & 566.333 & 0,3480 & 443.000 & 0,3210 & 35.300 \\
\hline 6 horas & 0,3280 & 376.333 & 0,2770 & 206.333 & 0,2740 & 196.333 \\
\hline 12 horas & 0,3280 & 376.333 & 0,2420 & 89.667 & 0,2680 & 176.333 \\
\hline 1 dia & 0,3560 & 300.800 & 0,2080 & 4.800 & 0,2850 & 158.800 \\
\hline 3 dias & 0,3380 & 264.800 & 0,1660 & -79.200 & 0,2650 & 118.800 \\
\hline 5 dias & 0,3210 & 343.000 & 0,1670 & -170.333 & 0,2300 & 39.667 \\
\hline 7 dias & 0,3200 & 339.667 & 0,1610 & -190.333 & 0,2060 & -40.333 \\
\hline
\end{tabular}

APÊNDICE B6 - Curva de viabilidade celular (concentração de macrófagos) em função da solução e tempo do ensaio experimental 2

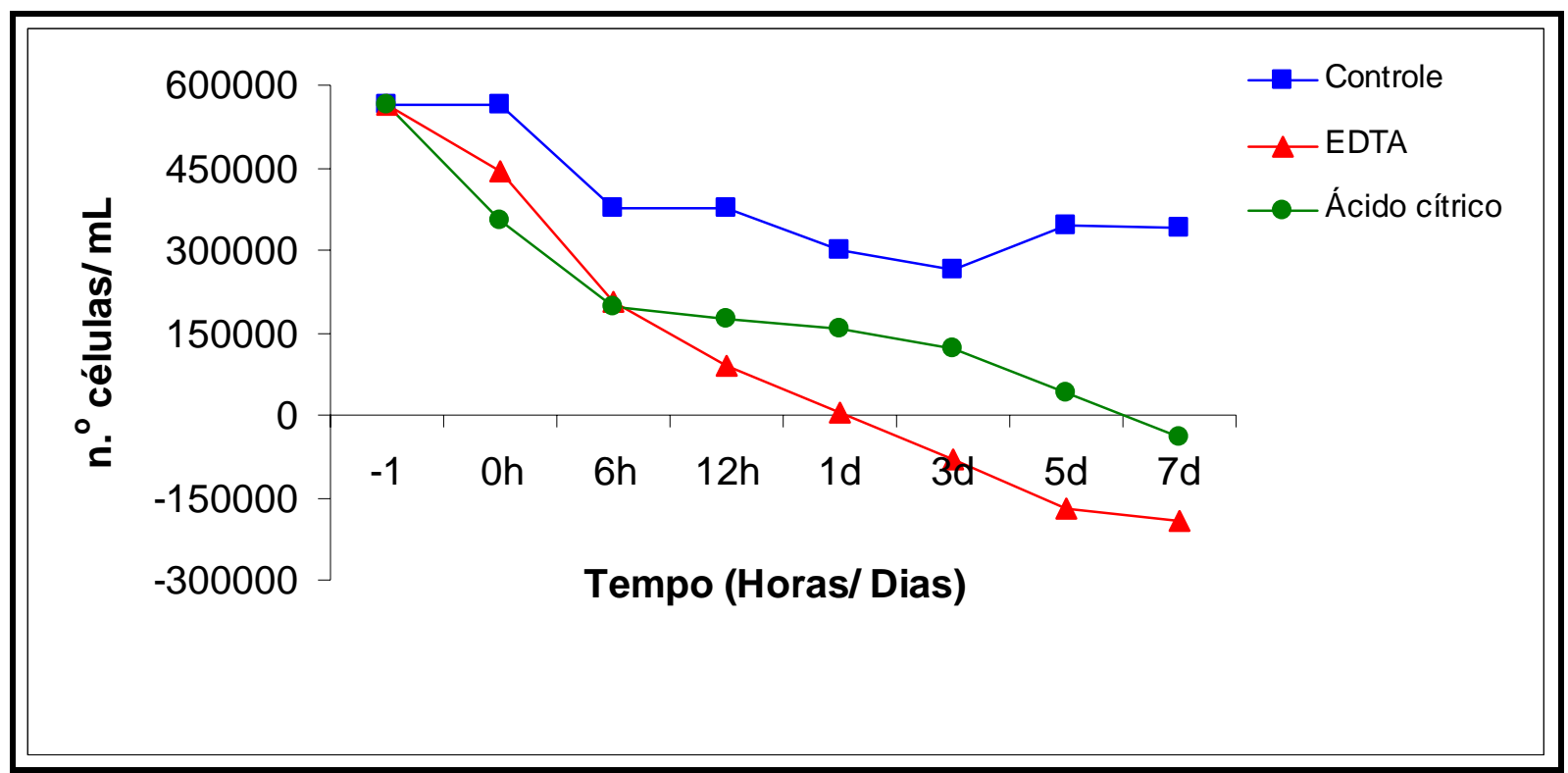


ANEXO A - Parecer do Comitê de Ética

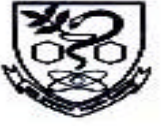

UNIVERSIDADE DE SÃO PAULO

Faculdacle de Ciências Farmaceuticas
Comissbo de Etica em Experimentacto Animal

arees $\rightarrow 20$

\section{CERTIFICADO}

Certificamos que o Projeto "Amdise da chotoxicidade e da simese de citocinas por macrofagos peritoneais in vitro, induzidos por soluçdes de EDTA e dido citrico" (Protocolo $n^{\circ} 19$ ), sob a responsabilidade do(a) Sr(a). Kall Fatima Amaral e do orientador(a) Giulio Gavini. está de acordo com os Principios Éticos na Experimentaçäo Animal adotado pelo Colégio Brasileiro de Experimentação Animal (COBEA) e foi aprovado pela Comissão de Ética em Experimentação Animal (CEEA) desta Faculdade, em 04/08/2003.

São Paulo, OS de agosto de 2003.

Eluriele Pacchi

Prof. Assoc. Elfriede Marianne Bacchi Coordenadora da CEEA 
ANEXOS B

ANEXO B1 - Tabulação dos valores de absorbância $(\mathrm{nm})$, referentes ao período de curto prazo de observação

\begin{tabular}{|c|c|c|c|c|c|c|c|c|c|c|c|c|c|c|c|c|c|c|}
\hline \multirow[b]{3}{*}{ Amostras } & \multicolumn{6}{|c|}{ Controle } & \multicolumn{6}{|c|}{ EDTA } & \multicolumn{6}{|c|}{ Ácido cítrico } \\
\hline & \multicolumn{3}{|c|}{ Ensaio 1} & \multicolumn{3}{|c|}{ Ensaio 2} & \multicolumn{3}{|c|}{ Ensaio 1} & \multicolumn{3}{|c|}{ Ensaio 2} & \multicolumn{3}{|c|}{ Ensaio 1} & \multicolumn{3}{|c|}{ Ensaio 2} \\
\hline & 1 & 2 & 3 & 4 & 5 & 6 & 1 & 2 & 3 & 4 & 5 & 6 & 1 & 2 & 3 & 4 & 5 & 6 \\
\hline 0 Horas & 0.420 & 0.362 & 0.411 & 0.385 & 0.392 & 0.378 & 0.289 & 0.275 & 0.285 & 0.362 & 0.337 & 0.344 & 0.277 & 0.275 & 0.263 & 0.322 & 0.319 & 0.321 \\
\hline 6 Horas & 0.330 & 0.366 & 0.343 & 0.334 & 0.327 & 0.323 & 0.244 & 0.235 & 0.257 & 0.280 & 0.275 & 0.275 & 0.225 & 0.217 & 0.238 & 0.274 & 0.275 & 0.272 \\
\hline 12 Horas & 0.294 & 0.570 & 0.231 & 0.329 & 0.331 & 0.324 & 0.215 & 0.220 & 0.218 & 0.242 & 0.244 & 0.241 & 0.233 & 0.218 & 0.230 & 0.269 & 0.267 & 0.268 \\
\hline 24 Horas & 0.332 & 0.331 & 0.335 & 0.341 & 0.371 & 0.356 & 0.192 & 0.206 & 0.202 & 0.211 & 0.206 & 0.208 & 0.222 & 0.190 & 0.198 & 0.294 & 0.284 & 0.276 \\
\hline
\end{tabular}


ANEXO B2 - Curto prazo - Coluna estatística referente aos grupos experimentais. Normalidade da amostra

\begin{tabular}{|c|c|c|c|}
\hline & Controle & EDTA & Ácido cítrico \\
\hline Number of values & 24 & 24 & 24 \\
\hline Minimum & 0.3372 & 0.2042 & 0.2440 \\
\hline \multicolumn{4}{|l|}{ 25\% Percentile } \\
\hline Median & 0.3454 & 0.2455 & 0.2488 \\
\hline \multicolumn{4}{|l|}{ 75\% Percentile } \\
\hline Maximum & 0.3913 & 0.3153 & 0.2962 \\
\hline Mean & 0.3548 & 0.2526 & 0.2595 \\
\hline Std. Deviation & 0.02466 & 0.04783 & 0.02460 \\
\hline Std. Error & 0.01233 & 0.02391 & 0.01230 \\
\hline Lower 95\% Cl & 0.3156 & 0.1765 & 0.2203 \\
\hline Upper 95\% Cl & 0.3941 & 0.3287 & 0.2986 \\
\hline \multicolumn{4}{|l|}{ Normality Test } \\
\hline KS distance & 0.3823 & 0.1819 & 0.3972 \\
\hline$P$ value & $P>0.10$ & $P>0.10$ & $P>0.10$ \\
\hline Passed normality test $\left({ }^{*}=0.05\right) ?$ & Yes & Yes & Yes \\
\hline$P$ value summary & ns & ns & ns \\
\hline
\end{tabular}


ANEXO B3 - Curto prazo - Coluna estatística referente ao tempo experimental

\begin{tabular}{|c|c|c|c|c|}
\hline & 0 Horas & 6 Horas & 12 Horas & 24 Horas \\
\hline Number of values & 18 & 18 & 18 & 18 \\
\hline Minimum & 0.2630 & 0.0275 & 0.2150 & 0.0206 \\
\hline 25\% Percentile & 0.2870 & 0.2410 & 0.2305 & 0.2000 \\
\hline Median & 0.3295 & 0.2745 & 0.2430 & 0.2490 \\
\hline 75\% Percentile & 0.3700 & 0.3250 & 0.2815 & 0.3315 \\
\hline Maximum & 0.4200 & 0.3660 & 0.5700 & 0.3710 \\
\hline Mean & 0.3343 & 0.2690 & 0.2747 & 0.2436 \\
\hline Std. Deviation & 0.05036 & 0.07483 & 0.08333 & 0.1026 \\
\hline Std. Error & 0.01187 & 0.01764 & 0.01964 & 0.02418 \\
\hline Lower 95\% Cl & 0.3092 & 0.2318 & 0.2332 & 0.1925 \\
\hline Upper 95\% Cl & 0.3593 & 0.3062 & 0.3161 & 0.2946 \\
\hline \multicolumn{5}{|l|}{ Normality Test } \\
\hline KS distance & 0.1490 & 0.1879 & 0.2493 & 0.1897 \\
\hline$P$ value & $P>0.10$ & $P>0.10$ & $P>0.10$ & $P>0.10$ \\
\hline Passed normality test $\left({ }^{*}=0.05\right) ?$ & Yes & Yes & Yes & Yes \\
\hline$P$ value summary & ns & ns & ns & ns \\
\hline
\end{tabular}


ANEXO B4 - Curto prazo - Análise de variância para 2 fatores de variação

\begin{tabular}{|c|c|c|c|c|}
\hline \multicolumn{5}{|l|}{ Two-way ANOVA } \\
\hline Source of Variation & $\%$ of total variation & $P$ value & & \\
\hline Interaction & 3.30 & 0.4084 & & \\
\hline Substância & 48.70 & $P<0.0001$ & & \\
\hline Tempo & 16.28 & $P<0.0001$ & & \\
\hline Source of Variation & $P$ value summary & Significant? & & \\
\hline Interaction & ns & No & & \\
\hline Substância & $\star \star \star ~$ & Yes & & \\
\hline Tempo & $\star \star \star ~$ & Yes & & \\
\hline Source of Variation & $D f$ & Sum-of-squares & Mean square & $F$ \\
\hline Interaction & 6 & 0.01062 & 0.001770 & 1.041 \\
\hline Substância & 2 & 0.1567 & 0.07836 & 46.07 \\
\hline Tempo & 3 & 0.05240 & 0.01747 & 10.27 \\
\hline Residual & 60 & 0.1020 & 0.001701 & \\
\hline Number of missing values & 0 & & & \\
\hline
\end{tabular}


ANEXO B5 - Curto prazo - Teste de Tukey (Substância)

\begin{tabular}{|c|c|c|c|c|}
\hline Parameter & Value & & & \\
\hline \multicolumn{5}{|l|}{ Repeated Measures ANOVA } \\
\hline$P$ value & 0.0003 & & & \\
\hline$P$ value summary & $\star \star \star ~$ & & & \\
\hline Are means signif. different? $(P<0.05)$ & Yes & & & \\
\hline Number of groups & 3 & & & \\
\hline$F$ & 44.28 & & & \\
\hline$R$ squared & 0.9365 & & & \\
\hline \multicolumn{5}{|l|}{ Was the pairing significantly effective? } \\
\hline$R$ squared & 0.2385 & & & \\
\hline$F$ & 9.870 & & & \\
\hline$P$ value & 0.0098 & & & \\
\hline$P$ value summary & ** & & & \\
\hline Is there significant matching? $(P<0.05)$ & Yes & & & \\
\hline ANOVA Table & sS & $d f$ & MS & \\
\hline Treatment (between columns) & 0.02612 & 2 & 0.01306 & \\
\hline Individual (between rows) & 0.008733 & 3 & 0.002911 & \\
\hline Residual (random) & 0.001770 & 6 & 0.0002949 & \\
\hline Total & 0.03662 & 11 & & \\
\hline Tukey's Multiple Comparison Test & Mean Diff. & $q$ & $P$ value & $95 \% \mathrm{Cl}$ of diff \\
\hline Controle vs EDTA & 0.1022 & 11.90 & $P<0.001$ & 0.06495 to 0.1395 \\
\hline Controle vs Ácido cítrico & 0.09538 & 11.11 & $P<0.001$ & 0.05812 to 0.1326 \\
\hline EDTA vs Ácido cítrico & -0.006833 & 0.7958 & $P>0.05$ & -0.04409 to 0.03043 \\
\hline
\end{tabular}


ANEXO B6 - Curto Prazo - Teste de Tukey (Tempo)

\begin{tabular}{|c|c|c|c|c|}
\hline Parameter & Value & & & \\
\hline \multicolumn{5}{|l|}{ Repeated Measures ANOVA } \\
\hline$P$ value & 0.0002 & & & \\
\hline$P$ value summary & 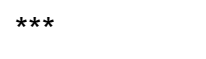 & & & \\
\hline Are means signif. different? $(P<0.05)$ & Yes & & & \\
\hline Number of groups & 4 & & & \\
\hline$F$ & 7.862 & & & \\
\hline$R$ squared & 0.3162 & & & \\
\hline \multicolumn{5}{|l|}{ Was the pairing significantly effective? } \\
\hline$R$ squared & 0.5112 & & & \\
\hline$F$ & 4.589 & & & \\
\hline$P$ value & $P<0.0001$ & & & \\
\hline$P$ value summary & $* * *$ & & & \\
\hline Is there significant matching? $(P<0.05)$ & Yes & & & \\
\hline ANOVA Table & SS & $d f$ & MS & \\
\hline Treatment (between columns) & 0.07959 & 3 & 0.02653 & \\
\hline Individual (between rows) & 0.2632 & 17 & 0.01548 & \\
\hline Residual (random) & 0.1721 & 51 & 0.003374 & \\
\hline Total & 0.5149 & 71 & & \\
\hline Tukey's Multiple Comparison Test & Mean Diff. & $q$ & $P$ value & $95 \% \mathrm{Cl}$ of diff \\
\hline 0 Horas vs 6 Horas & 0.06525 & 4.766 & $P<0.01$ & 0.01375 to 0.1167 \\
\hline 0 Horas vs 12 Horas & 0.05961 & 4.354 & $P<0.05$ & 0.008112 to 0.1111 \\
\hline 0 Horas vs 24 Horas & 0.09071 & 6.625 & $P<0.001$ & 0.03921 to 0.1422 \\
\hline 6 Horas vs 12 Horas & -0.005639 & 0.4118 & $P>0.05$ & -0.05714 to 0.04586 \\
\hline 6 Horas vs 24 Horas & 0.02546 & 1.860 & $P>0.05$ & -0.02604 to 0.07696 \\
\hline 12 Horas vs 24 Horas & 0.03110 & 2.271 & $P>0.05$ & -0.02040 to 0.08260 \\
\hline
\end{tabular}




\section{ANEXOS C}

ANEXO C1 - Tabulação dos valores de absorbância $(\mathrm{nm})$, referentes ao período de médio prazo de observação

\begin{tabular}{|c|c|c|c|c|c|c|c|c|c|c|c|c|c|c|c|c|c|c|}
\hline & \multicolumn{6}{|c|}{ Controle } & \multicolumn{6}{|c|}{ EDTA } & \multicolumn{6}{|c|}{ Ácido cítrico } \\
\hline & \multicolumn{3}{|c|}{ Ensaio 1} & \multicolumn{3}{|c|}{ Ensaio 2} & \multicolumn{3}{|c|}{ Ensaio 1} & \multicolumn{3}{|c|}{ Ensaio 2} & \multicolumn{3}{|c|}{ Ensaio 1} & \multicolumn{3}{|c|}{ Ensaio 2} \\
\hline Amostras & 1 & 2 & 3 & 4 & 5 & 6 & 1 & 2 & 3 & 4 & 5 & 6 & 1 & 2 & 3 & 4 & 5 & 6 \\
\hline $1 \mathrm{Dia}$ & 0.332 & 0.331 & 0.335 & 0.341 & 0.371 & 0.356 & 0.192 & 0.206 & 0.202 & 0.211 & 0.206 & 0.208 & 0.222 & 0.190 & 0.198 & 0.294 & 0.284 & 0.276 \\
\hline 3 Dias & 0.312 & 0.310 & 0.311 & 0.333 & 0.336 & 0.345 & 0.137 & 0.131 & 0.127 & 0.167 & 0.169 & 0.163 & 0.211 & 0.206 & 0.205 & 0.263 & 0.266 & 0.265 \\
\hline 5 Dias & 0.260 & 0.263 & 0.265 & 0.314 & 0.322 & 0.326 & 0.107 & 0.104 & 0.132 & 0.165 & 0.165 & 0.170 & 0.191 & 0.184 & 0.163 & 0.233 & 0.227 & 0.230 \\
\hline 7 Dias & 0.238 & 0.239 & 0.234 & 0.312 & 0.328 & 0.320 & 0.114 & 0.112 & 0.119 & 0.163 & 0.159 & 0.160 & 0.178 & 0.181 & 0.171 & 0.206 & 0.207 & 0.206 \\
\hline
\end{tabular}


ANEXO C2 - Médio prazo - Coluna estatística referente aos grupos experimentais. Normalidade da amostra

\begin{tabular}{|c|c|c|c|}
\hline & Controle & EDTA & Ácido cítrico \\
\hline Number of values & 24 & 24 & 24 \\
\hline Minimum & 0.2785 & 0.1378 & 0.1915 \\
\hline \multicolumn{4}{|l|}{ 25\% Percentile } \\
\hline Median & 0.3081 & 0.1448 & 0.2203 \\
\hline \multicolumn{4}{|l|}{ 75\% Percentile } \\
\hline Maximum & 0.3443 & 0.2042 & 0.2440 \\
\hline Mean & 0.3098 & 0.1579 & 0.2190 \\
\hline Std. Deviation & 0.03010 & 0.03123 & 0.02500 \\
\hline Std. Error & 0.01505 & 0.01561 & 0.01250 \\
\hline Lower 95\% Cl & 0.2619 & 0.1082 & 0.1793 \\
\hline Upper 95\% Cl & 0.3576 & 0.2076 & 0.2588 \\
\hline \multicolumn{4}{|l|}{ Normality Test } \\
\hline KS distance & 0.2260 & 0.3619 & 0.2512 \\
\hline$P$ value & $P>0.10$ & $P>0.10$ & $P>0.10$ \\
\hline Passed normality test $\left({ }^{*}=0.05\right) ?$ & Yes & Yes & Yes \\
\hline$P$ value summary & ns & ns & ns \\
\hline
\end{tabular}


ANEXO C3 - Curto prazo - Coluna estatística referente ao tempo experimental

\begin{tabular}{|c|c|c|c|c|}
\hline & 1 Dia & 3 Dias & 5 Dias & 7 Dias \\
\hline Number of values & 18 & 18 & 18 & 18 \\
\hline Minimum & 0.1900 & 0.1270 & 0.1040 & 0.1120 \\
\hline 25\% Percentile & 0.2060 & 0.1680 & 0.1650 & 0.1615 \\
\hline Median & 0.2490 & 0.2370 & 0.2090 & 0.1935 \\
\hline 75\% Percentile & 0.3315 & 0.3105 & 0.2615 & 0.2360 \\
\hline Maximum & 0.3710 & 0.3450 & 0.3260 & 0.3280 \\
\hline Mean & 0.2642 & 0.2365 & 0.2123 & 0.2026 \\
\hline Std. Deviation & 0.06630 & 0.07685 & 0.06992 & 0.06664 \\
\hline Std. Error & 0.01563 & 0.01811 & 0.01648 & 0.01571 \\
\hline Lower $95 \% \mathrm{Cl}$ & 0.2312 & 0.1983 & 0.1775 & 0.1695 \\
\hline Upper 95\% Cl & 0.2971 & 0.2747 & 0.2470 & 0.2357 \\
\hline \multicolumn{5}{|l|}{ Normality Test } \\
\hline KS distance & 0.2376 & 0.1639 & 0.1196 & 0.1404 \\
\hline$P$ value & $P>0.10$ & $P>0.10$ & $P>0.10$ & $P>0.10$ \\
\hline Passed normality test $\left({ }^{*}=0.05\right) ?$ & Yes & Yes & Yes & Yes \\
\hline$P$ value summary & ns & ns & ns & ns \\
\hline
\end{tabular}


ANEXO C4 - Médio prazo - Análise de variância para 2 fatores de variação

\begin{tabular}{|c|c|c|c|c|}
\hline \multicolumn{5}{|l|}{ Two-way ANOVA } \\
\hline Source of Variation & $\%$ of total variation & $P$ value & & \\
\hline Interaction & 1.14 & 0.5238 & & \\
\hline Substância & 74.83 & $P<0.0001$ & & \\
\hline Tempo & 10.90 & $P<0.0001$ & & \\
\hline Source of Variation & $P$ value summary & Significant? & & \\
\hline Interaction & ns & No & & \\
\hline Substância & *** & Yes & & \\
\hline Tempo & 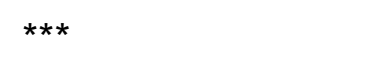 & Yes & & \\
\hline Source of Variation & $D f$ & Sum-of-squares & Mean square & $F$ \\
\hline Interaction & 6 & 0.004268 & 0.0007114 & 0.8680 \\
\hline Substância & 2 & 0.2803 & 0.1401 & 171.0 \\
\hline Tempo & 3 & 0.04084 & 0.01361 & 16.61 \\
\hline Residual & 60 & 0.04917 & 0.0008196 & \\
\hline Number of missing values & 0 & & & \\
\hline
\end{tabular}


ANEXO C5 - Médio Prazo - Teste de Tukey (Substância)

\begin{tabular}{|c|c|c|c|c|}
\hline Parameter & Value & & & \\
\hline \multicolumn{5}{|l|}{ Repeated Measures ANOVA } \\
\hline$P$ value & $P<0.0001$ & & & \\
\hline$P$ value summary & 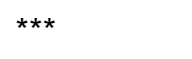 & & & \\
\hline Are means signif. different? $(P<0.05)$ & Yes & & & \\
\hline Number of groups & 3 & & & \\
\hline$F$ & 197.0 & & & \\
\hline$R$ squared & 0.9850 & & & \\
\hline \multicolumn{5}{|l|}{ Was the pairing significantly effective? } \\
\hline$R$ squared & 0.1255 & & & \\
\hline$F$ & 19.14 & & & \\
\hline$P$ value & 0.0018 & & & \\
\hline$P$ value summary & ** & & & \\
\hline Is there significant matching? $(P<0.05)$ & Yes & & & \\
\hline ANOVA Table & SS & $d f$ & MS & \\
\hline Treatment (between columns) & 0.04671 & 2 & 0.02336 & \\
\hline Individual (between rows) & 0.006807 & 3 & 0.002269 & \\
\hline Residual (random) & 0.0007114 & 6 & 0.0001186 & \\
\hline Total & 0.05423 & 11 & & \\
\hline Tukey's Multiple Comparison Test & Mean Diff. & $q$ & $P$ value & $95 \% \mathrm{Cl}$ of diff \\
\hline Controle vs EDTA & 0.1519 & 27.90 & $P<0.001$ & 0.1283 to 0.1755 \\
\hline Controle vs Ácido cítrico & 0.09071 & 16.66 & $P<0.001$ & 0.06709 to 0.1143 \\
\hline EDTA vs Ácido cítrico & -0.06117 & 11.24 & $P<0.001$ & -0.08479 to -0.03754 \\
\hline
\end{tabular}


ANEXO C6 - Médio prazo - Teste de Tukey (Tempo)

\begin{tabular}{|c|c|c|c|c|}
\hline Parameter & Value & & & \\
\hline \multicolumn{5}{|l|}{ Repeated Measures ANOVA } \\
\hline$P$ value & $P<0.0001$ & & & \\
\hline$P$ value summary & $\star * *$ & & & \\
\hline Are means signif. different? $(P<0.05)$ & Yes & & & \\
\hline Number of groups & 4 & & & \\
\hline$F$ & 53.08 & & & \\
\hline$R$ squared & 0.7574 & & & \\
\hline \multicolumn{5}{|l|}{ Was the pairing significantly effective? } \\
\hline$R$ squared & 0.8560 & & & \\
\hline$F$ & 73.55 & & & \\
\hline$P$ value & $P<0.0001$ & & & \\
\hline$P$ value summary & $* * *$ & & & \\
\hline Is there significant matching? $(P<0.05)$ & Yes & & & \\
\hline ANOVA Table & SS & $d f$ & MS & \\
\hline Treatment (between columns) & 0.04084 & 3 & 0.01361 & \\
\hline Individual (between rows) & 0.3206 & 17 & 0.01886 & \\
\hline Residual (random) & 0.01308 & 51 & 0.0002565 & \\
\hline Total & 0.3746 & 71 & & \\
\hline Tukey's Multiple Comparison Test & Mean Diff. & $q$ & $P$ value & $95 \% \mathrm{Cl}$ of diff \\
\hline 1 Dia vs 3 Dias & 0.02767 & 7.330 & $P<0.001$ & 0.01347 to 0.04186 \\
\hline 1 Dia vs 5 Dias & 0.05189 & 13.75 & $P<0.001$ & 0.03769 to 0.06609 \\
\hline 1 Dia vs 7 Dias & 0.06156 & 16.31 & $P<0.001$ & 0.04736 to 0.07575 \\
\hline 3 Dias vs 5 Dias & 0.02422 & 6.417 & $P<0.001$ & 0.01002 to 0.03842 \\
\hline 3 Dias vs 7 Dias & 0.03389 & 8.978 & $P<0.001$ & 0.01969 to 0.04809 \\
\hline 5 Dias vs 7 Dias & 0.009667 & 2.561 & $P>0.05$ & -0.004531 to 0.02386 \\
\hline
\end{tabular}




\section{ANEXOS D}

ANEXO D1 -Valores médios do padrão 1 (ensaio 1 e 2), referentes aos períodos de 0, 6 e 12 horas

\begin{tabular}{|c|c|c|c|c|c|c|c|}
\hline & Branco & $10^{3}$ & $10^{4}$ & $10^{5}$ & $5 \times 10^{5}$ & $7.5 \times 10^{5}$ & $10^{6}$ \\
\hline Number of values & 4 & 4 & 4 & 4 & 4 & 4 & 4 \\
\hline Minimum & 0.1460 & 0.1540 & 0.1540 & 0.2380 & 0.3830 & 0.4410 & 0.5460 \\
\hline \multicolumn{8}{|l|}{ 25\% Percentile } \\
\hline Median & 0.1710 & 0.1760 & 0.2105 & 0.2585 & 0.4035 & 0.4715 & 0.5490 \\
\hline \multicolumn{8}{|l|}{ 75\% Percentile } \\
\hline Maximum & 0.1830 & 0.1970 & 0.2600 & 0.2660 & 0.4190 & 0.5100 & 0.5620 \\
\hline Mean & 0.1678 & 0.1758 & 0.2088 & 0.2553 & 0.4023 & 0.4735 & 0.5515 \\
\hline Std. Deviation & 0.01721 & 0.02290 & 0.05925 & 0.01220 & 0.01482 & 0.03034 & 0.007550 \\
\hline Std. Error & 0.008606 & 0.01145 & 0.02962 & 0.006102 & 0.007409 & 0.01517 & 0.003775 \\
\hline Lower 95\% Cl & 0.1404 & 0.1393 & 0.1145 & 0.2358 & 0.3787 & 0.4252 & 0.5395 \\
\hline Upper 95\% Cl & 0.1951 & 0.2122 & 0.3030 & 0.2747 & 0.4258 & 0.5218 & 0.5635 \\
\hline \multicolumn{8}{|l|}{ Normality Test } \\
\hline KS distance & 0.2617 & 0.2873 & 0.3065 & 0.2745 & 0.2433 & 0.1953 & 0.2668 \\
\hline$P$ value & $P>0.10$ & $P>0.10$ & $P>0.10$ & $P>0.10$ & $P>0.10$ & $P>0.10$ & $P>0.10$ \\
\hline $\begin{array}{l}\text { Passed normality test } \\
\left({ }^{*}=0.05\right) ?\end{array}$ & Yes & Yes & Yes & Yes & Yes & Yes & Yes \\
\hline$P$ value summary & ns & ns & ns & ns & ns & ns & ns \\
\hline
\end{tabular}


ANEXO D2 - Curva-padrão obtida a partir da média das curvas-padrão dos ensaios experimentais $1 \mathrm{e}$ 2 , referente aos períodos de 0,6 e 12 horas

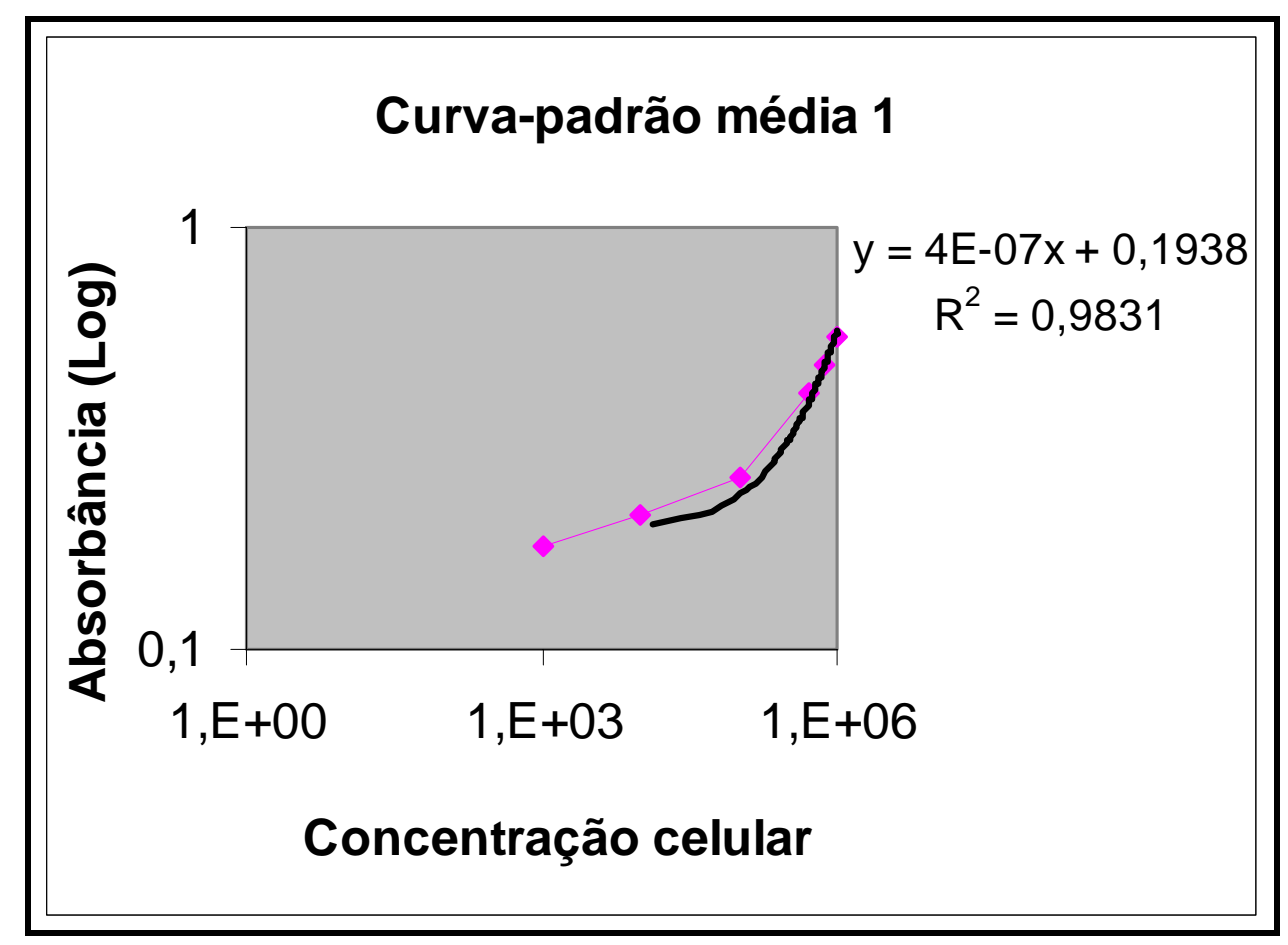


ANEXO D3 - Valores médios do padrão 2 (ensaio 1 e 2), referentes aos períodos de 1 e 3 dias

\begin{tabular}{|c|c|c|c|c|c|c|c|}
\hline & Branco & $10^{3}$ & $10^{4}$ & $10^{5}$ & $5 \times 10^{5}$ & $7.5 \times 10^{5}$ & $10^{6}$ \\
\hline Number of values & 4 & 4 & 4 & 4 & 4 & 4 & 4 \\
\hline Minimum & 0.1330 & 0.1320 & 0.1320 & 0.2080 & 0.3890 & 0.4750 & 0.5440 \\
\hline \multicolumn{8}{|l|}{ 25\% Percentile } \\
\hline Median & 0.1585 & 0.1655 & 0.1955 & 0.2375 & 0.3995 & 0.5200 & 0.5915 \\
\hline \multicolumn{8}{|l|}{ 75\% Percentile } \\
\hline Maximum & 0.1900 & 0.1980 & 0.2600 & 0.2640 & 0.4290 & 0.5630 & 0.6490 \\
\hline Mean & 0.1600 & 0.1653 & 0.1958 & 0.2368 & 0.4043 & 0.5195 & 0.5940 \\
\hline Std. Deviation & 0.03127 & 0.03669 & 0.07304 & 0.02986 & 0.01727 & 0.04491 & 0.05324 \\
\hline Std. Error & 0.01564 & 0.01835 & 0.03652 & 0.01493 & 0.008635 & 0.02246 & 0.02662 \\
\hline Lower $95 \% \mathrm{Cl}$ & 0.1102 & 0.1069 & 0.07953 & 0.1892 & 0.3768 & 0.4480 & 0.5093 \\
\hline Upper 95\% Cl & 0.2098 & 0.2236 & 0.3120 & 0.2843 & 0.4317 & 0.5910 & 0.6787 \\
\hline \multicolumn{8}{|l|}{ Normality Test } \\
\hline KS distance & 0.3060 & 0.2990 & 0.3048 & 0.2916 & 0.3246 & 0.2721 & 0.2794 \\
\hline$P$ value & $P>0.10$ & $P>0.10$ & $P>0.10$ & $P>0.10$ & $P>0.10$ & $P>0.10$ & $P>0.10$ \\
\hline $\begin{array}{l}\text { Passed normality test } \\
\left({ }^{*}=0.05\right) ?\end{array}$ & Yes & Yes & Yes & Yes & Yes & Yes & Yes \\
\hline$P$ value summary & ns & ns & ns & ns & ns & ns & ns \\
\hline
\end{tabular}


ANEXO D4 - Curva-padrão obtida a partir da média das curvas-padrão dos ensaios experimentais $1 \mathrm{e}$ 2 , referente aos períodos de 1 e 3 dias

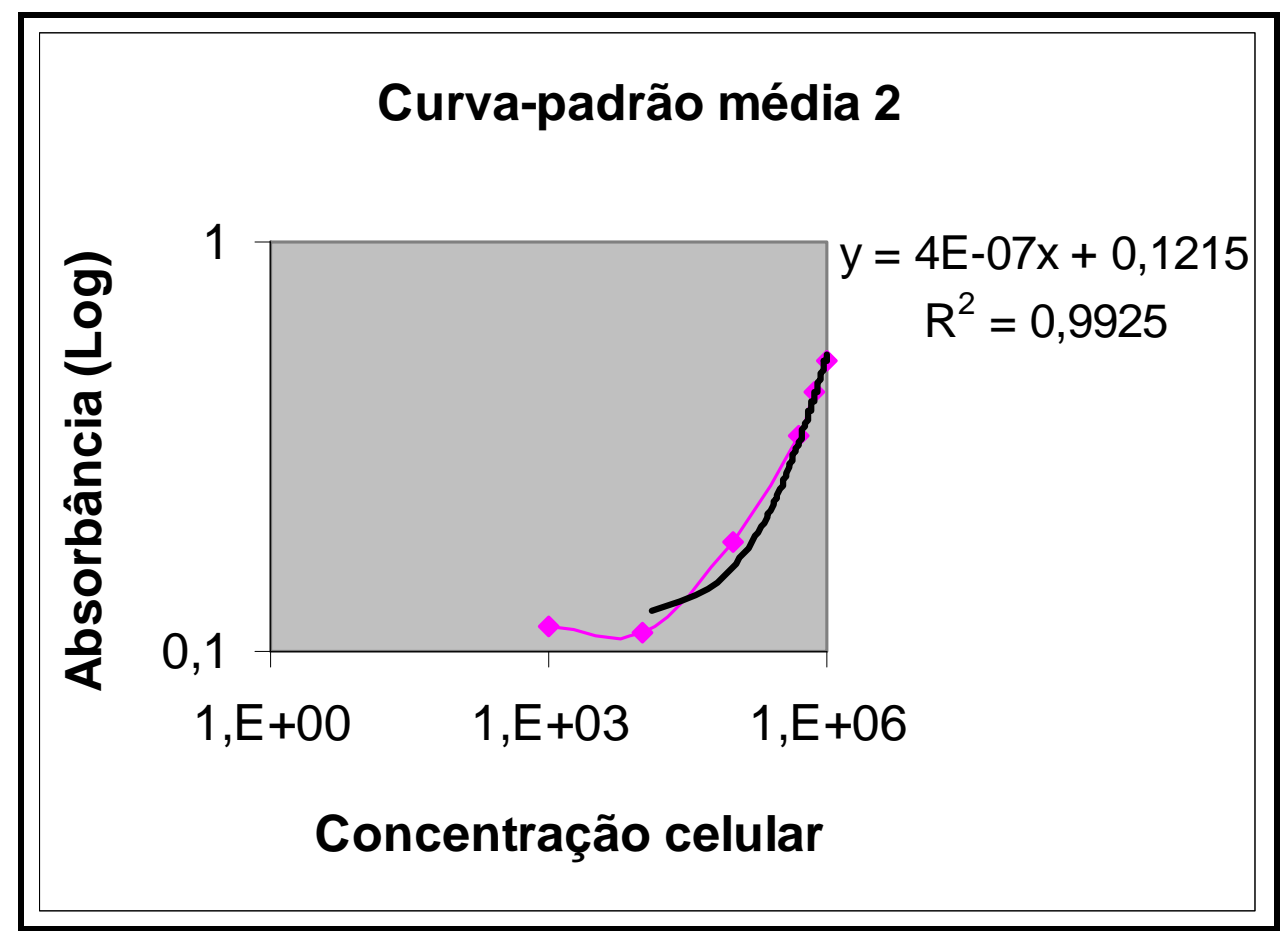


ANEXO D5 - Valores médios do padrão 3 (ensaio 1 e 2), referentes aos períodos de 5 e 7 dias

\begin{tabular}{|c|c|c|c|c|c|c|c|}
\hline & Branco & $10^{3}$ & $10^{4}$ & $10^{5}$ & $5 \times 10^{5}$ & $7.5 \times 10^{5}$ & $10^{6}$ \\
\hline Number of values & 4 & 4 & 4 & 4 & 4 & 4 & 4 \\
\hline Minimum & 0.1110 & 0.1100 & 0.1100 & 0.1840 & 0.3210 & 0.3940 & 0.4590 \\
\hline \multicolumn{8}{|l|}{ 25\% Percentile } \\
\hline Median & 0.1115 & 0.1145 & 0.1105 & 0.1840 & 0.3410 & 0.4310 & 0.5220 \\
\hline \multicolumn{8}{|l|}{ 75\% Percentile } \\
\hline Maximum & 0.1210 & 0.1180 & 0.1150 & 0.1870 & 0.3510 & 0.4750 & 0.5490 \\
\hline Mean & 0.1138 & 0.1143 & 0.1115 & 0.1848 & 0.3385 & 0.4328 & 0.5130 \\
\hline Std. Deviation & 0.004856 & 0.0035 & 0.002380 & 0.001500 & 0.0150 & 0.03433 & 0.03826 \\
\hline Std. Error & 0.002428 & 0.00175 & 0.001190 & 0.0007500 & 0.007500 & 0.01716 & 0.01913 \\
\hline Lower 95\% Cl & 0.1060 & 0.1087 & 0.1077 & 0.1824 & 0.3146 & 0.3781 & 0.4521 \\
\hline Upper 95\% Cl & 0.1215 & 0.1198 & 0.1153 & 0.1871 & 0.3624 & 0.4874 & 0.5739 \\
\hline \multicolumn{8}{|l|}{ Normality Test } \\
\hline KS distance & 0.3907 & 0.1915 & 0.3332 & 0.4415 & 0.2977 & 0.1448 & 0.3123 \\
\hline$P$ value & $P>0.10$ & $P>0.10$ & $P>0.10$ & $P>0.10$ & $P>0.10$ & $P>0.10$ & $P>0.10$ \\
\hline $\begin{array}{l}\text { Passed normality test } \\
\left({ }^{*}=0.05\right) ?\end{array}$ & Yes & Yes & Yes & Yes & Yes & Yes & Yes \\
\hline$P$ value summary & ns & ns & ns & ns & ns & ns & ns \\
\hline
\end{tabular}


ANEXO D6 - Curva-padrão obtida a partir da média das curvas-padrão dos ensaios experimentais 1 e 2 , referente aos períodos de 5 e 7 dias

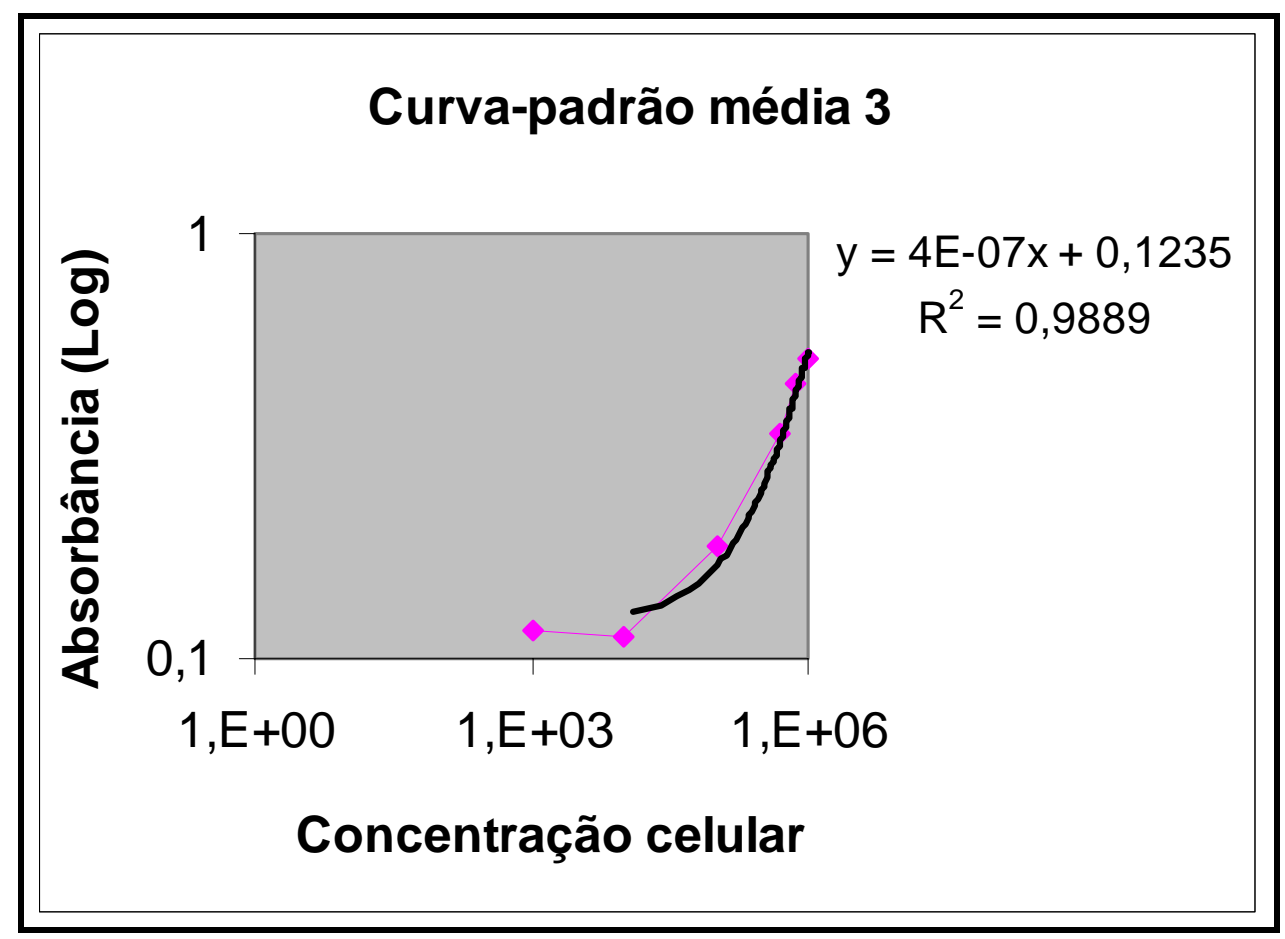

